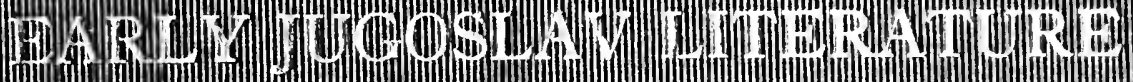 $400404-10300$
}

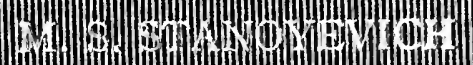



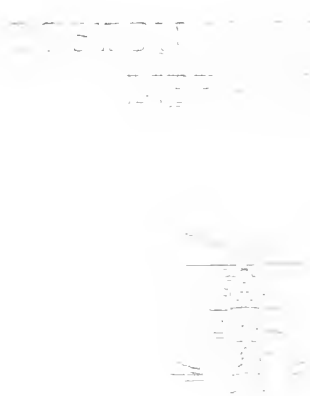

$-1-2=-1$ 

COLUMBIA UNIVERSITY SLAVONIC STUDIES

Vol.. I

EARLY JUGOSLAV LITERATURE 
COLUMBIA UNIVERSITY PRESS

SALES AGENTS

NEW YORK

LEMCKE \& BUECHNER

30-32 EAST 2OTH STREeT

LONDON

HUMPHREY MILFORD

AMEN CORNer, E.C.

SHANGHAI

EDWARD EVANS \& SONS, LTD.

3o North Szechuen Road 


\section{EARLY JUGOSLAV LITERATURE (IOOO-I 800)}

BY

MILIVOY S. STANOYEVICH, Ph.D.

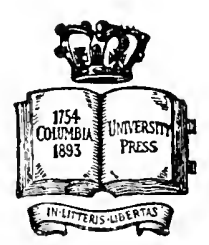

Rew Mork

COLUMBIA UNIVERSITY PRESS

1922

All rights reseried 
Copyright, 1922

By Columbia University Press

Printed from type. Published January, 1922 


\section{CONTENTS}

CHAPTER

vii-viii

Preface.

Introduction . . . . . . . . . . . . . . . I-5

\section{FIRST PERIOD}

THE ORIGINS

I. Old Slavonic Language . . . . . . . . . . 7-14

II. Old Slavonic Literature . . . . . . . . . . . I5-28

\section{SECOND PERIOD}

THE AGE OF RENAISSANCE

III. Republic of Dubrovnik and the Renaissance . . 29-37

IV. The Poets of the I5th Century . . . . . . . . 38-42

V. Lyrics and Drama of the I6th Century . . . . 43-49

VI. Gundulić and his Times (I 7 th Century) . . . . 50-56

\section{THIRD PERIOD}

THE AGE OF DECLINE

VII. The Academies and Societies . . . . . . . 57-60

VIII. The Moralists and Minor Authors . . . . . 6I-69

IX. Epilogue . . . . . . . . . . . 70-71

Bibliography . . . . . . . . . . . 73-75

Index . . . . . . . . . . . . . $77-91$ 



\section{PREFACE}

The object of the present treatise, as indicated by the title given to it, may seem sufficiently comprehensive. In the small space allotted to me it has only been possible to cover the main facts of the subject without professing to be exhaustive. But I trust that even these outlines, scanty as they are, will be of use as giving some idea of the historical course of literary evolution, and I hope that at some future time they may be more adequately filled out. The actual facts presented here have been chiefly drawn from the original sources. The old MSS. and published works of individual authors, in the larger European and American libraries, form the basis upon which I have relied in preparing this study. However, I have also made use of much of what has already been written in the monographs of many Slavonic historians and in several Jugoslav publications indicated in the footnotes and bibliography.

With respect to the orthography and transliteration of the Slavonic words, use is made here of the system adopted by the Jugoslovenska Akademija Znanosti $i$ Umetnosti (The Jugoslav Academy of Sciences and Arts), namely:

$$
\begin{aligned}
& \hat{C}-\hat{c} \text { for English } t i \text { or } c h \text { in tune, literature } \\
& \text { Č- } \\
& \text { Š-̌ “ " " ssi " sh " passion, fish } \\
& \check{Z}_{-} \check{z} \text { “ " " si " } z h \text { " vision, azure } \\
& \text { Đ-đ " " " } d i \text { " } d y \text { " duke, } d \text { une } \\
& \mathrm{I}-1 \text { " “ " } \quad \text { " } l i \text { " } l y \text { " million, failure } \\
& \hat{\mathrm{N}}-\mathrm{n} \text { “ “ } \quad \text { " } g n \text { “ } n y \text { “ mignon, pinion } \\
& \hat{\mathrm{G}}-\dot{\mathrm{g}} \text { " “ } \quad d g \text { “ } g \text { " bridge, stage }
\end{aligned}
$$

I owe much more than is apparent in these pages to the kindness of my esteemed friends Professors J. D. Prince and J. B. Fletcher, of Columbia University, who have suggested to me verbally at some length many valuable hints as to the 
viii EARLY JUGOSLAY LITERATURE

general treatment of the subject. Without their unflagging interest and encouragement this volume would not have been written. My gratitude is also due to Dr. C. A. Manning for his special technical help, and to the librarians of Columbia, Harvard, Yale and the Slavonic Division of the New York Public Library, who have enabled me, in almost all cases, to write from a first-hand acquaintance with the literature.

M. S. S.

NEW YORK

April 9, I921 


\section{EARLY JUGOSLAV LITERATURE}

\section{INTRODUCTION}

The history of a language is the history of the people who speak it or have spoken it. Virtually it is the history of many tribes, different in origin, manners, and speech. When the people of another powerful race succeeded in crushing these tribes, they usually took possession of the conquered land, and allowed the others to live only on condition of being quiet and doing all the work. It is to these conquests, kept up throughout the Middle Ages, that the majority of European nations owe their geographical limits and even their present names. Their establishment has been mainly the result of greed and military power. New societies have been formed out of the wrecks of the older ones which were violently destroyed, but in the work of reconstruction they have always retained something of their previous existence in their internal constitution and especially in their language.

Languages, like nations, have their periods of growth, maturity, and decay, but while nine-tenths of the vocabulary of a people lives in the literature and speech of the cultured classes, the remainder has a robust life in the daily usage of the sons of toil. This limited but more persistent portion of the national speech never fails to include the names of those objects which are the most familiar and the most beloved. Such are, for instance, the names of the nearest relatives, father, mother, brother, two or three of the commoner metals, tools, weapons, cereals, domestic animals; the house and the most striking features in the landscape; the mountain peaks and ranges; the valleys, lakes and rivers; the sun, the moon, the stars, the sky and the clouds. At all times and in every region of the world, these names have had the same clear and well-defined meanings; their visible forms stand as a sort of material lexicon, explaining the more archaic forms of living languages that have ceased to be vernacular. 
Many nations have left no written records, and their history would be a blank volume, or nearly so, were it not that in the places where they have sojourned they have left traces of their migrations sufficiently clear to enable us to reconstruct the outlines of their history. The hills, the valleys, and the rivers are the only writing-tablets on which unlettered nations have been able to inscribe their annals, and these may be read in the names that still cling to the sites, and often contain the records of a class of events about which written history is for the most part silent. These connotations which originally had a descriptive import, referring mostly to the physical features of the land, have even the advantage over the common names of a nation's speech of being less subject to the process of phonetic decay. They seem to be possessed of an inherent and indestructible vitality which makes them survive invasions and catastrophes. Wars can trample down or extirpate whatever grows upon a soil, excepting only its native plants and the names of those sites upon which man has established his domicile. Seldom is a people utterly exterminated, for the proud conqueror has need of some at least of the natives to till the soil anew. These enslaved outcasts, though they may hand down no memory of the splendid deeds of the nation's heroes, yet retain a most tenacious recollection of the names of the hamlets which their progenitors inhabited, and near to which their fathers were interred. Ethnographical nomenclature and national tradition are therefore an important factor in all that concerns a nation's early history, and they often furnish most effectual aid in the solution of linguistic problems.

If, then, we would trace the Slavonic languages to their sources, the course to be pursued is clearly marked out. The subject, which covers a wide range of interesting studies, involves, first of all, a critical inquiry into the origin, character, and distribution of the Slavonic race-Russians, Ukrainians, Bulgars, Jugoslavs, Čechoslovaks, and Poles. At various epochs these nations have found their way into central and southeastern Europe and created there new religions, new idioms, and new oral and written literatures. From the complexity of the subject, it is obvious that all these details are not the fruit of any one man's learning, but the result of long 
patient labors of many specialists in each of these branches. Availing ourselves of the latest researches of the distinguished scholars whose names we quote as our authorities, and whose acknowledged learning and accuracy need no commendation, we here present a comparative digest of their substance, so arranged as to be neither reduced to the skeleton of a mere abridgment, nor extended to the huge dimensions of a learned work. Supposing the reader to be familiar with at least the outlines of Slavonic literary history, we will not treat it in its entirety or in all the different branches. We will rather dwell on the early literature of one branch-the Southern Slavs or Jugoslavs, who are mainly composed of three peoples of the same race: Serbs, Croats and Slovenes. In the course of time common interests drew these people together and brought about a corresponding fusion of their idioms. The traces of their language and literature are still so clearly marked that they easily indicate the degree of power and adherence to national speech and customs which was displayed by each branch in their present unification and amalgamation.

The term Jugo-Slav (South-Slav) as now used by most European peoples, has a wider signification than that which it originally bore. The Southern Slavs call themselves Jugosloveni, and their land Jugoslavija. This is composed of several provinces. In the beginning of the last century one of these provinces (Serbia) gave birth to a few military leaders who became formidable to the invaders of the nation's liberties, and their deeds are known in the IVest. The name was then extended so as to include the whole people and country which is called Jugoslavia, just as the tribe of Angles, though numerically inferior to the Saxons, gave their name to England and all that the term English now denotes. As the Angles, Saxons and Jutes merged in one British people, and the dialects of Northumbria, Mercia and Wessex in one English tongue, so in Jugoslavia the inhabitants of Serbia, Croatia, and Slovenia blended in one Jugoslav people, and their kindred idioms practically in one Serbian or Croatian language, which is also, for better understanding, called in Slavonic philology Serbo-Croatian. 
The Jugoslav writers of the 17 th and 18 th centuries: Antun Kanižlic, Emerik Pavić, Matija Relković and especially Igńat Đorđić, Jeronim Kavańin, and Andra Kačić Miošić, very of ten mention the words Iliria, Ilir and Ilirički. They thought that these Latin derivatives (Illyria, Illyrius and Illyricus) corresponded to the meaning of Jugoslavija, Jugosloven and Jugoslovenski - the terms created later on in the I 9 th century. Nevertheless the old Illyria known from the remote ages of the Greeks and Romans has nothing but a part of its territory in common with the Jugoslavs. The conquest of Illyria by the Serbs and Croats began early in the seventh century. In their penetration from Galicia and the Carpathian Mountains to the South and Southwest, the Serbs occupied the eastern half of Illyria while the Croats and Slovenes settled in the western part. Forming permanent settlements in the Balkan Peninsula the Slavs have profoundly modified the ethnical character and the usages of the Illyrians. Not long after this migration had taken place, the aboriginal indigenous Illyrian tribes were scattered all over the peninsula. Many have been absorbed and Slavonized, and those that have been able to resist the Slavic civilization and language are now represented by the Albanians.

When the Southern Slavs came to the Balkans they brought with them their primitive tribal institutions, organized on a basis partly patriarchal (zadruga, family community), and partly political (župa, county). Several zadrugas formed a pleme (plur. plemena, clans), and several clans were united into a military organization known as županija (shire), of which the military leader was called župan (sometimes $k n e z$, chieftain or prince). These županias were originally independent of each other, and did not at first acknowledge any alien sovereign. In the course of time those Slavonic clans that settled in the extreme west gradually passed under Roman and those in the east and south-east under Byzantine influence. In the 9th century almost all the Jugoslavs abandoned their old paganism and adopted Christianity. As the new religion came from Rome and Greece, two empires living in permanent disputes, the first Jugoslav literature of religious character appears as a constant struggle between native and exotic elements. It is 
difficult for a foreigner to be attracted by these early rudiments of literature which have more historical and linguistic than literary value, and which comprise in this study the epoch from the roth until the end of the I 4 th century. This literature was written in the Old Slavonic language, flourished in the great united Serbian State, and vanished with the conquest of that State by the Turks (1389).

The second period may justly be called the period of renaissance. It embraces the age from the end of the I4th to the middle of the 17 th century. This literature was no longer written in the old Slavonic dialects but in the pure SerboCroatian vernacular. It has no relation with the literature of the ancient period but relies rather on classical models and grew up under the shadow of the earlier civilization of Italy.

The third period presented here is the age of decline. It started after the earthquake in Dalmatia (1667), and lasted to the close of the 18 th century. This literature was mostly cultivated in Croatia, Dalmatia and Slovenia. Roman Catholic influence prevailed everywhere, and only few authors are to be found of any importance.

The Jugoslav literature of the new era (19th to 2oth century) including the folklore, is more developed, and by virtue of extraordinary richness and variety of its forms, occupies a larger space in a literary history of the Jugoslavs than the literature of any preceding period of the same duration. It is quite modern and possesses a peculiar fascination, but for the present it does not enter into our consideration. 



\title{
FIRST PERIOD
}

\author{
THE ORIGINS
}

\section{CHAPTER I}

\section{OLD SLAVONIC LANGUAGE}

The Old Slavonic language belongs to the Indo-Eurcpean family. The parentage of the tongue with other Aryan languages stands out clearly if one compares the oldest examples of its original literature with Paleo-Greek or ancient Gothic. In the continuous development of the Indo-European stock, the different languages separated themselves by the ordinary processes of dialectic differentiation and formed distinct branches which gave birth, in their turn, to new phases, just as if each branch contained in itself the germs of an entire group of organisms which were later developed. So was particularized the branch to which are attached the GermanoBalto-Slavonic group. In this grouping the Germanic first diverged; then the Lithuanian, Lettic and Slavonic, each taking on an independent existence. The Slavonic finally itself produced an entirely new series of tongues, dialects and sub-dialects.

\section{I}

By the middle of the $9^{\text {th }}$ century the biblical and liturgical books had been translated by Cyril and Methodius, the "Apostles to the Slavs," into a Slavonic dialect which probably was spoken in Macedonia and the hinterland of Thessalonica, or Salonika, where these missionaries were born and lived in their boyhood. The Slavs, like all primitive peoples, practiced divination at first with črtami $i$ rězami (marks and cuts) on wood. ${ }^{1}$ Later the Southern Slavs used an alphabet called

'See "Zapiska mniha Hrabra o slovima slovenskim" in S. Novaković, Primeri kńiževnosti i jezika staroga i srpsko-slovenskoga (1904), p. 204. 
Glagolitic (Glagolica, from glagol, a word, letter, verb), which has survived as a liturgical script in certain parts of northern Dalmatia. ${ }^{2}$ After their baptism the Slavs were compelled to write the Slavonic tongue with Greek and Latin script, without any proper rule. Constantine, named Cyril in monastic life, was the first teacher who made them an alphabet of 38 letters, hence the name Cyrillic (Cirilica). The question, into which Slavonic dialect the church books were translated, is still unsettled. The older German savants, Schleicher, Brugmann, Schmidt and Leskien, asserted that this dialect was the Old Bulgarian language. ${ }^{3}$ The Serbian scholars, Solarić, ${ }^{4}$ Karaǵić, Daničić and some of the Russian historians, believed that this was Old Serbian, while the noted Slavonic philologists Kopitar, Miklošić, Vondrák and Jagić, maintained that Old Slavonic was identical with Old Slovene (of the Pannonic Slavs) as it was spoken in the province of Pannonia, in the 9th century. But there is no doubt that in such decisions much was due to racial and local patriotism or political sentiments. ${ }^{5}$

As the liturgical literary organ of the church, the ProtoSlavonic dialect completely outgrew its original domain. It spread gradually from province to province wherever divine service was carried on in the Slavonic tongue. It penetrated to

${ }^{2}$ Cf. V. Vondrák "Zur Frage nach der Herkunft des glagolitischen Alpha. bets," Archiv f. slav. Philol. XVIII (1896), 54I ff., XIX (1897), 167 ff.

3 "In the meantime if this was really Old Bulgarian how would one call the language spoken by the Bulgars before they have been Slavonized," asks T. Maretić in his work Slaieni u Davnıni (the Slavs in Antiquity), p. 102 (1902). Of the same opinion is Prof. J. D. Prince, when he expressively declares that "Church Slavonic is not Old Bulgarian, but simply stood in a very close relationship to the Slavonic dialect adopted by the Non-Slavonic Bulgars." See his article "A rare Old Slavonic religious manual" in Proceedings of the American Philos. Soc. LV (1916), n.5, p. 359.

4According to Solarić the Old Slavonic is stari srpski dialekat (old Serbian dialect), quot. by N. Andrić, Rad jug. akad. CI. (I902), p. 153.

' It is natural to conjecture that the Proto-Slavonic dialect which was used by Cyril and Methodius in their translations of the Scripture, was the tongue of the Macedonian Slavs, who lived between the Pindus and the Rhodope. Cf. Const. Jireček, Geschichte der Serben (History of the Serbians), bk. III, ch. 2, p. 176 (I9II), and S. Novaković, "Prvi osnovi slovenske kńiževnosti među balkanskim Slovenima" (1893), p. I28. 
all the South Slav lands, and was to be found among SerboCroats, Bulgars and the Eastern Slavs (Russians). In all these regions the church language prevailed according to medieval conceptions, both as the national and the common speech, just as the Latin type did among the Roman and Teutonic peoples. In exercising its "civil" functions it laid itself open to the different local influences, as to intonation, formation, form and a continually enlarging vocabulary. Since the I I th century one can accurately speak of the Serbian, the Russian and the Bulgarian recensions, or rather of SerboSlavonic, Russo-Slavonic, Bulgaro-Slavonic and Croato-Glagolitic. It must be observed that the Church Slavonic of the Middle Ages even took into its scope for a considerable time, tongues which were not Slavonic. This happened to Rumanian in the south, and to Letto-Lithuanian in the north.

Along the Adriatic Sea divine service was performed mostly in Slavonic. In southern Dalmatia the chronicles mention the appointment of the Catholic archbishoprics from the IIth century onwards. They expressly refer to the Monasteria tam Latinorum quam Graecorum sive Sclavorum, which differed from each other according to the language of their liturgical books. But there started in northern Dalnatia great struggles which are not settled even today. While the Orient since ancient times has been accustomed to church-books in different languages, Latin has been the prevailing language in the West. The two great Churches of medieval Christianity, the Catholic and the Orthodox, touched each others' borders before the gates of the Dalmatian cities. The Slavonic apostles themselves had a tense struggle in Moravia and Pannonia against the German clergy. In the diocese of Splet (Spalato) the Slavonic Catholic liturgy of the Croatians was persecuted by the Romans. Because of lack of knowledge the Glagolitic church-books were regarded by those who used the Latin as Gothic or Aryan. In the I3th century, a new theory arose, and even to this day persists in the national tradition, which ascribed the authorship of these books to no less a person than St. Jerome (346-420). Of him the old Croatian texts speak as the founder of ancient Jugoslav literature, as svetla kruna 
hrvatskoga jezika (the sparkling crown of the Croatian language), and say that he was a Slav from Dalmatia. ${ }^{6}$ However, modern linguistics and the publication of Slavonic documents by the philologists, Geitler, Sobolevskij, Sreznevskij, and Vondrák, have thrown more light on this question. It was discovered that the Glagolitic originated in South Dalmatia (Dioclea) in the time of Constantine (Cyril) and that it was not much older than the Cyrillic script. The old strife confined itself after these discoveries only to provincial and nationalistic disputes. ${ }^{7}$

The sway of Church Slavonic as the medieval literary speech of all the Orthodox Slavs lasted many centuries. In Russia it obtained until the time of Peter the Great, and among the Serbs and Bulgars until the end of the I8th century. Peter the Great put the first obstacle in the way of the monopoly of Church Slavonic as the Russian literary speech. He ordained a new form, a kind of modernized letter adopted under Dutch influence, and called this the civil alphabet (graždanskaja $a z \hat{o} u k a$, or simply graこ̃danka) in opposition to the ecclesiastic alphabet. The hitherto superfluously ornamented letters and characters of the abbreviated words and expressions were kept in reserve for church use. Thus the Old Slavonic was limited only to liturgical purposes. Even theology and church oratory and administration were henceforth carried on in the new Russian language, which was used in the church service only on special occasions.

Among the Orthodox Southern Slavs, particularly the Serbians, a mixture of Church Slavonic in its Russian form with a popular rendering was in vogue to the end of the I 8 th century. Vuk Stefanović Karaǵić was the first reformer to shake off the remnants of this artificial dialect and to institute a phonetic orthography. The pure speech of the Serbian people came into its own as the common organ of officialdom and literature. The influence of Vuk Karaǵic in Bulgaria arrived somewhat later and more tardily. So even today all Orthodox Slavs have one and the same church language, which is essentially

${ }^{6}$ See "Život svetoga Jerolima." Starine jug. akad. I (1 869), p. 236.

7 See V. Jagić, Entstehungsgeschichte der kirchenslavischen Sprache, par. 46-47, pp. 243 sqq. (1913). 
restricted to church uses. The limits of its employment are much narrower than those allowed to Latin in the Catholic church. ${ }^{8}$

\section{II}

As to the ancient monuments in Old Slavonic, they were mostly written by clergymen of all ranks, and very often by the monarchs themselves, who either chose or were forced to renounce the throne and enter the monastic life. These scribes generally wrote their books in the peaceful retreat of a cloister: at Chilandar, Zograf, Studenica, Dečani, Rilo, and many another monastery in the Balkan Peninsula. Imitating Greek literature, which was very handy to them and extremely rich in content, they borrowed its spirit, its models and its themes. $^{9} \quad$ Next to theology comes hagiography, i.e., the literature of the acts of the martyrs and the lives of the saints, which the Slavs cultivated with great conscientiousness. All other kinds of prose writing on geography, philosophy, rhetoric and the technical sciences, were comparatively neglected. Such works are of value for the most part only in so far as they preserve and interpret old material. There have been collected up to now 5,000 manuscripts, which represent the production of old literature common to all Slavonic nations, but it cannot be affirmed that there are as many finished works.

The translation of the Scriptures by the two brothers Cyril (827-869) and Methodius (d. 885) was one of the most important monuments in the history of Slavonic literature. By their prodigious work a "barbarian" tongue was raised to the dignity of a literary language. It is not known exactly how much of the Scriptures the Slavonic apostles translated, but it seems probable that the whole of the Gospels was rendered

${ }^{8}$ Leroy-Beaulieu makes the Old Slavonic as the liturgical language responsible for the tardy development of the Russian language. On the other hand, he points out that the language of Cyril and Methodius, in spite of local alterations, has proved a firm bond between Orthodox Slitvonic peoples. "If Kyrie Eleison were sung in the Russian Church instead of Gospodi Pomiluy, there might never have been such a thing as Panslavism." The Empire of the Tsars and the Russians, III (1902), 2, pp. 75-76.

${ }^{9}$ Cf. M. Gaster, Ilchester Lectures on Greeko-Slavonic Literature (1887), pp. $10 f f$. 
into Slavonic by them. Some have asserted that the Old Testament was also translated, but this appears unlikely, since no ancient codex of it exists or has ever been proved to have existed. In the IIth century the Proverbs of Solomon certainly were to be found in Slavonic versions. The Book of Wisdom, Ecclesiastes, the Prophets and Job, were translated during the $13^{\text {th }}$ century in Serbia. Towards the close of the I5th century the whole Bible was already done into PaleoSlavonic. According to Dobrovský, the different parts of it were not collected till after I488, when the Čech Bible of Prague was printed.

After the death of Cyril and Methodius, Christianity and Slavdom began to take a firmer hold upon Serbia, Bulgaria, and Russia. Counting the Orthodox, the Russian sects, Uniats and Glagolitics, over Ioo million men today listen to the text of the Word of the Lord, as it was translated and interpreted by the two brothers from Salonica, more than a thousand years ago. ${ }^{10}$ After the decease of Methodius his numerous disciples were forced to leave Moravia, to seek shelter in Serbia and Bulgaria, and some of them went as far as Dalmatia. Wherever these missionaries sojourned they left traces of their literary activities either as translators or original authors. To them have been ascribed the biographies or legends of the apostles: one is Vita Constantini Philosophi or Žitie Konstanina Filosofa, and another Vita S. Methodii or Žitie sv. Metodia."

${ }^{10}$ On Cyril and Methodius there is an extensive literature. The most important monographs are: J. Dobrovský, Cyrill und Method, des Slaven Apostel (1823); F. Rački, Vek i delovańe sv. Cirila $i$ Metoda (I, I857; II, I859); V. Bilbasov, Kirill $i$ Methodij, 2 vols. (1868-7I); A. Hilferding, O Kirillě $i$ Metloodie (Complete Works, I, 299-340); L. Leger, Cyrille et Méthode (1868); J. A. Ginzel, Geschichte der Slavena postel Cyrill und Method (186I); A. d'Avril, St. Cyrille et St. Méthode (1902); A. D. Voronov, Kiril $i$ Methodij; Glavnějšie istočniki dlja istorii sv. Kirilla i Methodia (1877); F. Pastrnek, Dějini slozianských apoštoli̊, Cyrilla a Methoda (1902).

${ }^{11}$ To the legends of Cyril and Methodius have been given the name of Pannonic, Moravian, Serbian, Bulgarian, Italian, etc., according to the country from which they are supposed to have sprung. The best texts of I'ita Constantini, Latin and Serbo-Slavonic, are published by E. Dümmler and F. Miklošić in Denkschriften der Wiener Akademie; Philos. histor. Klasse, XIX (1870), 203-248. A critical edition of Vita sancti Methodii, Latin and Russo-Slavonic text, is by F. Miklošić (Vienna, 1870). 
The real author of these biographies is not exactly known. They are to be found in a great number of works, which have a high historical value. They are gathered together in a book and translated into modern Russian by V. A. Bilbasov, Kirill $i$ Methodij (1868-187I). The Lives of Cyril and Methodius tempted many a writer's pen, and inspired a great quantity of works signed by the most eminent critics. The study of sources, particularly, has received considerable attention in our days. One might almost say that no modern historian has failed to contribute something concerning these two brothers. The researches of the first-class savants, such as Dobrovský, Šafařík, Rački, Miklošić, Jagić, Ginzel, Bilbasov, Voronov, and Pastrnek, called forth new studies and gave renewed impulse to future philologists and men of letters.

Other valuable documents in the old Jugoslav literature which have come down to us are the Slovenian Brizinski Spomeniki (the Freisingen Monuments) found in Freising, Bavaria. They are composed of a confession, a sermon and a prayer. The MS. is in Latin script and dates from the year c. Iooo, but the composition is older. The language is an adaptation of an old Slavonic translation. The oldest Croatian Glagolitic monument is an inscription on the Bašcanska Ploča (Baška Tablet) dating from I Ioo, while the oldest Serbian Cyrillic document is the Povela Bana Kulina (Covenant of Ban Kulin) a treaty made in I 189 between Kulin, Ban of Bosnia, and Krvaš, Knez (President or Prince) of the Republic of Ragusa. Far more stately works than these fragments and inscriptions, are the old codices and chronicles, the best extant specimens of the Paleo-Slavonic language and history. Most of them had been written in the period from the eleventh to thirteenth century. From the eleventh century have been preserved: Psalterium Sinaiticum (glagolitic) edited by L. Geitler, 1883; Codex Marianus (Quatuor Evangeliorum, glag.), ed. V. Jagić, I883; Glagolita Clozianus (glag.), ed. V. Vondrák, I893; and Savvina Kniga (Book of Sava, cyrillic), ed. by V. Ščepkin, 1903. From the twelfth century are: Codex Suprasliensis (cyr.), ed. S. Severjanov, I904; Evangelium Zographensis (glag.), ed. by V. Jagić, I 879; Gospel of Miroslav (cyrillic), ed. Isub. Stojanović, I 897; Gospel of Rheims or "Texte du Sacre" 
(glag. and cyr.), ed. L. Leger, I899; Chronicle of Presbyter Diocleus (originally Glag., transcriptions in Lat.), ed. Ivan Kukulevic.. ${ }^{12}$ The valuable monuments of the fourteenth century are: Apostolus of Šišatovac (cyr.) edited by F. Miklošić, I853; and Gospel of Nikoļa (cyr.), ed. by Đ. Daničić, I 864. These monuments possess not only paleographic but high historic value, since they are the first attempt to express in a Slavonic language ideas which have been hitherto foreign. Besides they are the first attempt to show an appreciation of the poetic capabilities of that language, which can hardly be too highly estimated. It is not too much to say that some of these codices possess literary grace and style which were not surpassed in any Slavonic prose for more than five or six centuries after they were written.

1: Arkiz za povesnicu jugoslovensku, I (1851), pp. I-37. New edition by Ivan Črnčić, Popa Dukjanina Letopis (Latin and Croatian), Kralevica, 1874. 


\section{CHAPTER II}

\section{OLD SLAVONIC LITERATURE}

\section{I}

Of enduring importance in the Jugoslav literature of the Middle Ages are poetry and worship, culminating in the songs of the church. These songs ministered far more copiously to the purposes of devotion and edification than architecture, painting and sculpture. Employing word and tone, they spoke more directly to the spirit than the plastic arts and gave more adequate expression to the whole wealth of the world of thought and emotion. Of the various species of sacred poetry, the hymn was the earliest and most important. The hymn was defined as "a lyrical discourse to the feelings." The Christian Church in all periods of its existence has been accustomed to use psalms and chants in public worship. The psalms are portions of the Psalms of David, and they have served as a model for composition of the hymns in the Orthodox Church. As the Greek text of the Psalms of David had no regular metrical structure, the earlier church hymns of the Eastern Church likewise were composed in a peculiar form. They usually begin with a strophe which forms the pattern of the succeeding ones, and is called in technical language hirmos (series), because it draws the others after it. The succeeding strophes are called troparia (versicles). A number of troparia, from three to twenty or more form an ode (O. Slav. pěsn) which corresponds to the Latin sequence. Eight odes (sometimes nine) form a canon, which represents the highest effort of Orthodox hymnody.

Another form of sacred anthems similar to the canon is the akathist ("theotokion") or ascription of praise to the Mother of God. The strophes of which the akathist is composed are called kontakia (Lat. canticum, O. Slav. kondak), and ikos (stanza). The kontakion is essentially the same as the troparion, and it is usually followed by the ikos, which is somewhat longer than the preceding strophe. 
All these chants, whatever their name may be, have no rhymes. They are divisible into verses (stichera), or clauses with regulated caesuras, but printed in the books as prose sentences. Each sentence has two to thirteen syllables, and these are in a continuous series, uniform, alternate or reciprocal. The metre being always syllabic, does not depend on the quantity of vowels or the position of consonants, but on a fixed proportion of accents. Those stichera that are not related in any way to other verses in the hymns, are called idiomela, and those which serve as the metrical and musical patterns of others are automela. Of less frequent occurrence in Old Slavonic hymnody are katisma and katavasia. Katisma are intercalated verses between the odes, and katavasia are repetitions of the hirmos of the odes.

The vast mass of texts exhibiting these various kinds of anthems are to be found in the Menea and the Octoechos, and above all in the liturgical books of the Orthodox Church. ${ }^{1}$ The texts themselves are for the most part anonymous, but a considerable number of them are the work of the most celebrated hymn-writers. The custom of writing hymns was so general and popular in the Middle Ages that bishops, patriarchs, and even the emperors, wrote them. Thus to the Emperor Justinian $(527-565)$ is ascribed a stirring troparion Jedinorodni Sine (The Only Begotten Son) which is now found in the Liturgies of St. Mark and St. Chrysostom. The medieval legends regarded Justinian as a Slav of Macedonia. ${ }^{2}$ $\mathrm{He}$ is the originator of the greatest code of laws that has ever been framed, and is the renewer of the magnificent Orthodox cathedral of St. Sophia in Constantinople which later served as the standard of the church Byzantine style. Being a diligent student and a person of some literary pretensions, he

1 These sources are supplemented by Kanonik, a collection of the Old Slavonic canons edited many times by several notable men. One of these collections is by Prof. Evgraf Lovjagin, Bogoslužebnye Kanony, izdanie vtoro (1875), and another by A. Maltzew, Andachtsbuch (Kanonik) der Orthodox-Katolischen Kirche des Morgenlandes, deutsch und slavisch (I 895).

${ }^{2}$ Cf. P. J. Šafařík, Slavische Alterthümer, vol. II, par. 29. Also J. Bryce, The English Historical Review, II (I 887), 657 f., and H. F. Tozer, Researches in the Highlands of Turkey, II (1869), 370 sq. 
wrote a good deal on theological topics and composed church hymns, of which the one mentioned is the best.

In the materials of the church hymn-books many songs were composed by St. Romanos and St. Sergius. Romanos, the poet of the sixth century, is the author of one thousand kontakia, among which the Déva Dnes (The Virgin Today) is one of the most popular. Krumbacher characterizes him as the "greatest poet of the Byzantine time." His surnames the "Melodist" and the "Christian Pindar" have been quite justified. ${ }^{3}$ Patriarch Sergius (610-64I) was the author of the celebrated akathist Vzbranoj Voevode (To the Champion Leader), composed as a thanksgiving to the Virgin Mary for her defense of Constantinople from the attack of Chaganes, king of Persia. Among other writers whose names are found in early church hymnology the most prominent are St. Andrew of Crete (660-732) and St. John of Damascus (8th century) the writers of canons. St. Sophronius (c. 630) and St. Germanus (c. 690) were the poets of idiomela, while St. Cosmas of Majumena (d. 760) and St. Joseph the Hymnographer (c. 840) won repute as the most prolific Christian poets.

All these hymns, originally written in Greek, were twice translated into Old Slavonic. The first version was made in the IIth century, but this translation was preserved only in a few of the oldest church books. They were again translated towards the close of the I4th century, and these last renderings are far superior to the first ones. Besides the translations there are many original hymns, especially in celebration of national saints, for instance the hymns to SS. Sava, Simeon, Stefan and other Serbian Orthodox saints. ${ }^{4}$

When we now turn to the other lights, we find that the is th, I2th, and I 3 th centuries, which practically coincide with the

${ }^{3}$ K. Krumbacher, Geschichte der byzantinischen Literatur (1897), p. $66 \hat{3}$.

${ }^{4}$ A vast number of these old original Serbian hymns will be found in Serblak or Srblak (Serbian Church-book) of which there are numerous editions. Some songs to Serbian saints (Pesme siecima Srbima) are published by Daničić in Glasnik srpskog učenog društva, IX (1857), 256-267, and fragmentary by S. Novaković. Primeri kńiž. i jez., 3 ed. (1904), 173-179. 
"golden" age of Serbian literary activity, were characterized by an output of historical prose writings. Such are the legends and the stories whose origin must also be sought in Greek sources. The Byzantines knew all the legends coming from the Orient or the Occident, that priceless material from which literature drew unstintingly. Through them many of these legends reached the Jugoslavs.

To this category belong, for example, The Book of Alexander, the epopee assigned to the Pseudo-Callisthenes which gave rise to a whole cycle of heroic romances and of which the Paleo-Slavonic literature possesses three different recensions. The oldest text of this story of Alexander the Great is in a manuscript of the 16 th century containing the translation of the chronicle of Malalas, which is merely the copy of a manuscript dating from I26I. The translation itself is unquestionably from a period still more remote. This edition and one other, of Serb recension, were current in Russia until the 18 th century. ${ }^{5}$ Another legendary history is the Trojanski Rat (Trojan War). Like other Greek myths it was current after the roth century; and was mostly known through the chronicle of Malalas; one edition of it can be found in the Vatican in a Bulgarian translation of Constantine Manasses (1 $4^{\text {th }}$ century). A. Vostokov recognizes in this work, so very different from the celebrated narratives of Dares the Phrygian and Diktys of Crete, a distinct popular inspiration. He believes that it has been a more or less accurate translation from the original Latin, which came from western Europe. New Glagolitic texts of the same romance have been discovered, in which it is difficult to detect any touches of the old Bulgarian rendering. Jagić has concluded that this legend (priča) in the Glagolitic text was first written in Bosnia or Dalmatia, where Latin models most easily made their appearance. ${ }^{6}$

5 The text of this book has been published in the Starine, jug. akad. III, I87I; the Glasnik, II odeleńe, v. IX, I878, and in other Slavonic publications.

${ }^{6} \mathrm{~V}$. Jagić, IIistorija kńiževnosti (1867), V, 3, p. $97 \mathrm{f}$. The Glagolitic text of "Trojan War" in his Primeri starohrvatskoga jezika, II (1866), and the Cyrillic in Arkiv za povesnicu jugoslovensku, IX (1868), I21-136. Miklošic has published the text with Latin translation according to the manuscript of Manasses in Starine jug. akad. III (1871), pp. 147-I88. 
From the IIth century date the legends of Barlaam and Josaphat, one of the most popular and widely disseminated of medieval romances, founded on the biography of Buddha, and the celebrated tales of Stephanit and Ichnilat, borrowed from the Indian fables of "Pančatantra." Both of these romances have been diffused throughout western Europe, not without having undergone serious modifications. The Slavonic text of the former is of the $\mathbf{I}^{5}$ th and the latter of the 13 th century. To this group of tales belongs also the Physiologus (Naturalist) a collection of stories, describing animals real or fabulous and giving each an allegorical interpretation. Thus the story is told of the lion whose cubs are born dead and receive life when the old lion (father) breathes upon them, and of the phoenix which burns itself to death and rises on the third day from the ashes; both are taken as types of Christ. The unicorn (inorog) also which only permits itself to be captured in the lap of a pure virgin is a type of the Incarnation; the pelican that sheds its own blood in order to sprinkle therewith its dead young, so that they may live again, is a type of the salvation of mankind by the death of Christ on the Cross. ${ }^{7}$ This book originated in the cities on the eastern and southern coast of the Mediterranean Sea among the writers of the Alexandrian school. That school was generally known with its taste for symbolism. It was written in the second century and in the Middle Ages formed the basis of numerous bestiaries and

7 Other animals are equally represented here, for instance, the charadrius (kaladrinon), a bird presaging recovery or death of sick people. The owl or nyktikorax, loves darkness and solitude. The eagle renews its youth by sunlight and bathing in a fountain. The hoopoe (popunac) redeems its parents from the ills of old age. The viper (aspida) is born at the cost of both its parents' death. The serpent (zmija) puts aside its venom before drinking, is afraid of man in a state of nudity, hides its head and abandons the rest of its body. The fox (lisica) catches birds by simulating death. The panther allures its prey, by sweet odor and sleeps for three days after meals. The partridge (jarebica) hatches eggs of other birds. The beaver (kastor) gives up its testes when pursued. The otter (enydria or vidra) enters the crocodile's mouth to kill it. The turtle-dove ( rlica) takes but one consort in its life. The swallow (lastavica) brings forth but once (in Aristotle: twice, "Hist. Animal." V, 13). The elephant (slon) conceives after partaking of mandrake, and brings forth in the water. The hyena is an hermaphrodite. The diamond found by night, and powerful against all danger. 
lapidaries, which influenced a great number of authors. Certain passages in Dante, ${ }^{8}$ Chaucer and Shakespeare would be unintelligible without some knowledge of these medieval text books of zoölogy. However, with the rapid progress of the natural sciences the Physiologus was abandoned by scholars and left to take its chances among the tales and traditions of the uneducated masses. Its symbols found their way into the rising literature of the vulgar tongues, and helped to quicken the fancy of the artists employed upon church buildings and furniture. The Jugoslav texts of the Physiologus exist only in late MSS. of the fifteenth century which have been considerably changed from the Greek and Syriac originals. ${ }^{9}$ One must not omit mentioning among documents whose Jugoslav origin is absolutely certain, the fantastic story of the Emperor Solomon and Kitovras, which is so well known even unto our day from the Russian manuscripts. There is a whole cycle of legends about this king, to whose wisdom, renowned in the Orient, was attributed a magic power over souls-surely a fit subject for the western epic of the Middle Ages. ${ }^{10}$

In some of the above mentioned legends we can easily detect traces of the influence of the Bogomils, a mystic sect which possessed many adherents in Bulgaria, Serbia and particularly in Bosnia, where they were called Patareni or Babuni. ${ }^{11}$

${ }^{8}$ Cf. R. T. Holbrook, Dante and the Animal Kingdom. Columbia University Press (1902). See in particular chapters: IX (the lion), ch. XII (the fox), XIII (the panther), XXVI (the beaver), XXVII (the otter), XXVIII (the elephant), XXXIX (the eagle), LVIII (the serpents), etc.

'The Serbo-Slavonic texts of the Physiologus were published by A. Aleksandrov, Fiziolog, Kazan, I 893 , and S. Novaković, "Slovo o veštih hodeštih i leteštih," Starine jug. akad., XI (1879), I81ff., and fragmentary in his Primeri Kńiževnosti i jezika, 3 ed. (I904), 584ff. For criticism see G. Polivka, "Zur Geschichte des Physiologus in den slavischen Literaturen," Archiv f. slav. Philol. XIV (1892), 374ff.; XV (I893), 246ff.; XVIIl (1896), 523 ff. A critical Greek text with German translation, notes and commentaries, was edited by F. Lanchert, Geschichte des Physiologus, Strassburg, I 889 .

10 The narratives of Solomon and Kitovras are familiar to us from the Russian renderings of the 15 th century. They have been widely circulated in popular poetry, in Serbian lore and Russian bylinas.

11 The Slavonic word Bogomil (Bog God + mil dear, a lover of God) is equivalent to the Greek Theophilos. The self-laudatory term of Cathari 
In Bosnia and Hum (Hercegovina) they had some special privileges and were protected by Ban Kulin, who was himself a converted Bogomil. This heresy began to spread among the Southern Slavs at the same time as Christianity. It probably came from Asia Minor, and was related to the Eastern dualistic system of philosophy. In common with other new Armenian and Manichean sects, the Bogomils accepted the dualism of the creative principle: the good personified in God, the evil personified in davo (devil), one representing the invisible and spiritual, the other the physical and tangible. They' wanted the abolition of the mass, the sacraments and the veneration of the saints. In state politics they were against capital punishment, armament and war. The spiritual tinge of their doctrine made them adverse to marriage from which their priests abstained totally. From a similar point of view we can explain another of their moral precepts, viz., vegetarianism, which was founded not on the nature-worship of Buddhism, or on Tolstoy's humanitarian enthusiasm, but on the abhorrence of the flesh and every thing begotten by it. Being a monotheistic sect they preferred the Mohammedan Allah to the Christian Trinity, and when the Turks conquered the Balkans most of them embraced Islam. There was a closer similarity between that religion and Bogomilism than between the latter and either the Eastern or Western Churches. This view is supported by the fact that in Bosnia and Hercegovina there are more Serbs of the Mohammedan religion (converted from the Bogomils) than in any other Jugoslav province. ${ }^{12}$

The teaching of the Bogomils exercised particular attraction upon the fertile imagination of the Slavic masses and fostered

("pure," hence "Puritans") assumed by those Bogomils in western Europe was converted by the Germans into the generic term of Ketzer or heretic. The Italian word Bugiardo, i.e., liar, and the French Bougre or Boulgre, i.e., rogue, are lasting testimonies of the repute in which Bulgarian veracity, deservedly or undeservedly was held; not to mention other similar epithets derived from the same root.

${ }^{12}$ For more of the Bogomils and their doctrine, see F. Rački, "Bogomili i Patareni," Rad jug. akad. 1870: VII (84-179), VIII (121-187), X (160263). C. Jireček, Geschichte der Bulgaren (History of the Bulgars), ch. IX, pp. I 55 ff. Prag, I 876 , and E. Gibbon, "The History of the decline and fall of the Roman Empire," ed. by J. B. Bury, v. VI (I902), pp. 540 sq. 
the growth of an extensive popular poetic literature which has long been neglected and condemned by the official Church. Of such writings are the apocrypha, some of which are most obscure and some of which actually did inspire the Old or the New Testament; one portion came from Byzantium, but another doubtless had a Bulgarian or Bogomil origin. The apocryphal books (lažne kńige) fall into different categories: works relating to certain personages or events in the Old or New Testaments which are not contained in the Christian canon; later works inspired by traditions and conceptions antipathetic to the Church; and finally books of magic, incantations and sorcery. The apocryphal writings, which are by their origin Oriental, i.e., strictly speaking apocryphal, became diffused throughout all Christian countries in the Middle Ages in spite of the condemnations and anathemas of the Church. They were to be found in France, England and Germany, just as in Ethiopia and Syria. The Middle Ages added another element to this literature, through its contribution of numerous legends and superstitions. Byzantine literature especially was rich in apocryphal writings and the Southern Slavs being neighbors to the Greeks borrowed from them. Slightly known until very recently, the Slavonic documents of this nature, in original or in translation, reveal to us a vast amount of the religious and popular poetry of the Orthodox Slavs. Many more Russian manuscripts have escaped destruction than Serbian, and they up to the present have been the chief source for the study of this most precious material. The Jugoslav origin of many apocryphal texts is now proved without a doubt, and this certainty will become more pronounced when there have been collected and published these manuscripts which have hitherto been but little studied. For a number of these apocrypha we have the originals; for a number of others the texts belong to the 13 th and even to the 12 th century, absolutely retaining the pure form of the Paleo-Slavonic characteristic of this period, the most remote of Jugoslav literature.

The notice of the Church was early attracted to these writings, and to keep the faithful from error the Church made up an index known under the name of a collection of "canonical 
and apocryphal books." The most ancient text of the canonical books is that of the Paleo-Slavonic Nomocanon (Krmčija or Zakonu pravilo), compiled by the Serbian Archbishop Sava in the $13^{\text {th }}$ century, ${ }^{13}$ while the paternity of numerous apocryphal books was attributed to Jeremiah, a Bulgarian priest.

The apocrypha are divided into two categories: those of the Old and those of the New Testament. Among the first are the Narratives of Adam, which contain certain details not included in the Bible concerning the life of Adam and Eve in the Garden of Paradise, their expulsion, the penitence of Adam, his sufferings, and his pact with the devil-all mingled with symbols announcing in advance the coming of the Sarior. ${ }^{14}$ Next in order comes the Book of Enoch, ${ }^{15}$ preserved in a manuscript of the I6th century under the name of the "Slavonic Enoch;" one of the Narratives of Abraham, ${ }^{16}$ his revelations and his death (in a manuscript of the 15 th century); and the legends relating to Solomon, already mentioned. In the Apocalypse of Baruch is presented Baruch's voyage to heaven, with poetic descriptions of dawn, twilight and other natural phenomena. ${ }^{17}$ Among the apocrypha most widely circulated are to be found the Paralipomena of Jeremiah, ${ }^{18}$ a story of the destruction of Jerusalem, and Isaiah's Vision, both in a manuscript of the 14th century.

Apocryphal literature relating to the New Testament is, in the main, composed of the following works: the Gospel of St. Thomas, ${ }^{19}$ which treats of the life of Christ (a manuscript of the

${ }^{13}$ See M. Murko, Geschichte der älteren südslavischen Literaturen, IX, 3, p. 149 (1908), and N. Milaš, Krmčija savinska, Zadar, I884.

${ }^{14}$ Serbo-Slavonic and Latin text with commentaries published by V. Jagić, "Die altkirchenslavischen Texte des Adambuches," Denkschriften der Wiener Akademie; Philos.-histor. Kl., XLII (1893), 1-I04.

${ }^{15}$ S. Novaković, "Apokrif o Enohu," Starine jug. akad. XVI (1884), 66 sq. An English translation by W. R. Morfill, The Book of the Secrets of Enoch, edit. R. H. Charles (I896).

${ }^{16} C f$. Comments and text by G. Polivka, "Die apokryphische Erzählung vom Tode Abrahams," Archiv f. slav. Philol. XVIII (I896), 112-I25.

${ }^{17}$ Edited by S. Novaković, "Otkriveńe Varuhovo," Starine jug. akad. XVIII (1886), pp. $203 f f$.

${ }^{18}$ Edited by G. Polivka, "Priča proroka Jeremije o pleńeńu Jerusalima," Starine jug. akad. XXI (I889), 22 I sq.

${ }^{19}$ Edited by P. A. Lavrov, A pokrifičeskie teksty (I899). 
I $5^{\text {th }}$ century); the Gospel of Nicodemus, ${ }^{20}$ on the sufferings and death of our Savior (the original from the 5 th and MS. from the $1^{\text {th }}$ and 16 th centuries); the Protevangelium of James, ascribed to St. James the Less, the brother of the Lord, containing the oldest story of the Conception of the Virgin extending to the death of Zacharius, written in the second century, of which the Slavonic MS. dates from the $15^{\text {th }}$ century; Abgar's Epistles, a legend describing how the Emperor Abgar of Edessa wrote a letter to Jesus Christ and received from Him a reply; ${ }^{21}$ the Acts of the A postles: Peter, Paul, Andrew, Mathew, Thomas and John. Then there is a long series of miraculous revelations which are not recognized among the canonical books: the Questions of the Apostle Bartholomew addressed to the Savior after His descent to hell and His resurrection; the Voyage of the Virgin in Hades, a very poetic narrative of a voyage which Mary made to the infernal regions and her intervention in favor of the fishermen (Serbian MS. from the I2th century); the Questions of John Bogoslov directed to the Lord on $\mathrm{Mt}$. Tabor, and to Abraham concerning the future life; the Voyage of the A postle Paul to the infernal regions; and the Discussions of the Patriarch Methodius about the pagan empire in recent times, the latter one of the most widely circulated pieces of ancient Jugoslav literature. ${ }^{22}$

Scientific study of the apocryphal books has recently led to curious discoveries about medieval Christian superstitions. The majority of the spurious documents have been discovered, but scientific analyses of them are far from being complete. We can affirm that from this time on we shall become better acquainted with the Slavs of these primitive times and that they will furnish us with surprising facts concerning the ancient popular and poetic literature of the East and the West. ${ }^{23}$

20 "Jevanđele Nikodimovo," ed. by Daničić, Starine jug. akad. IV (1872), pp. I3o sq. Also by Luub. Stojanović, Glasnik srp. uč. društ. LXIII (I885), pp. $89 \mathrm{ff}$. A discourse on this Gospel is by Polivka, in Casopis musea českého LXIV (I890) and LXV (I89I).

${ }^{21}$ The text by S. Novaković, Starine jug. akad. XVI (I884), 57 ff.

${ }^{22}$ Most of the last mentioned a pocrypha are published by N. Tihonravor: Pamjatniki otrečenoj russkoj literatury, tom II (I863).

${ }^{23}$ For further bulky materials on apocryphal literature in general, see P. A. Lavrov, A pokrifičeskie teksty, Petrograd, I899; M. N. Speranskij, 


\section{III}

Of much greater importance and wider diffusion than hagiographa and apocrypha in Old Slavonic literature are the stare srpske biografije (the ancient Serbian biographies) of the Serb rulers and archbishops. While the apocrypha, hagiographa and romances are mostly translations from Greek, the biographies are original works, and are the best representatives of ancient Jugoslav culture as well as valuable documents of bygone ages. ${ }^{24}$ The list of writers of this sort is headed by the name of a king: Stefan Prvovenčani, the "first crowned" (d. 1223), who wrote a biography of his father Nemańa, or Simeon in monastic life. ${ }^{25}$ Another biographer of the $13^{\text {th }}$ century is St. Sava (I I 7 I-1236), the youngest son of Nemańa, and the first Serbian archbishop. He also wrote a life of his father, Život sv. Simeuna, one of the most attractive literary relics of this period..$^{26}$ Besides this he left two Typiks (Statute-books), one made for the monastery of Chilandar: and another for the monastery of Studenica, of which he was hegumen.27 Many other writings of the same sort exist. St. Sava attained great glory among the Serbians for his efforts to spread general education among the people. He founded with his father on the peninsula of Athos the celebrated monastery of Chilandar (I192), which became one of the best known cen-

Slavjanskija apokrifičeskija evangelija, Moskva, 1895; A. N. Pypin, "Ložnyja i otrečennyja knigi russkoj stariny" in Pamjatniki starinoj russkoj literatury, III (1862) ed. by Gf. Gr. Kušelev-Bezborodko; N. S. Tihonravov, Pamjatniki otrečenoj russkoj literatury ( 2 vols. Moskva, I 863 ); Ivan Franko, A pokrifi $i$ legendy, I-IV (1896-1906). Jugoslav apocrypha are mostly published by Jagić and Novaković in Starine jug. akad., see especially vols. III (I869); IV (I87I); VI (I874); VIII (I876); X (I878); XI (I879); XVI (1884); XVIII (I886).

${ }^{24} \mathrm{Cf}$. S. Vulović, "Iz stare srpske kńiževnosti," Godiśníica Nikole Čupića, VII (1885), p. 88.

${ }^{25}$ Published by P. J. Šafařik, Památky dřevního písemnictví jihoslovanův, v Praze, I85I (2 ed. 1873 ). Another text by Pater Martynov in Pamjatniki drevnej pismennosti, III (I880), I9-70.

${ }^{26}$ Edited by Šafař́k, Glasnik srp. uč. druš. XX (I 866), 157 sq.

${ }^{27}$ Ed. J. K. Jireček, Glasnik srpskog učenog društva, XL (I874), I32 $s q$. One of the first chapters of the Typik for Studenica is Sava's biography of Nemańa, which later on was published as a separate work. 
ters of culture, attracting the Jugoslavs whose activity maintained Serbian independence for several centuries. In addition to Chilandar, the monasteries of Žiča, Mileševa, Dečani, Peć, Đurđevi Stubovi and Bańska must be mentioned. These were built by Nemańa himself or by the members of his dynasty. They were foci of religious culture and in the dark days became havens of refuge for the national traditions. ${ }^{28}$

The work of Sava was continued by one of his disciples, a Chilandar monk, Domentijan, ${ }^{29}$ who wrote a Life of St. Sava (I24I) and a Life of St. Simeon (1264). The former was revised in the 14 th century by a certain Teodosije. ${ }^{30}$ To Archbishop Danilo, who administered the Serbian church from I323-I338, a whole series of lives of Serbian kings is attributed: Radoslav, Vladislav, Uroš and his wife Queen Helena, Dragutin, Milutin and Stefan Dečanski. This collection, known later under the title of Carostavnik (Tsars' Chronicle) or Rodoslov (Genealogy), overflows with such a wealth of enthusiasm that its historical value suffers. In the first copies, which always bear the name of Danilo, the Rodoslov is carried to the end of the 18 th century. ${ }^{31}$ The Life of Stefan Dečanski was written by Gregory Camblak (Samblak or Tsamblak, I364-1420), a name which is met again in Russian history and which is a living proof of the literary unity which existed between Russia, Bulgaria, Serbia, and Rumania. Both Bulgarian and Serbian versions of this biography are extant. It is beyond doubt that the author himself endeavored to write in the true PaleoSlavonic or ecclesiastical style. ${ }^{32}$

P. Šafaŕik pretends that Serbian literature shows a greater originality and taste the more ancient it is. The narrative

${ }^{28}$ For a more extensive monograph of St. Sava, see A. Gavrilović, Sveti Sava. Beograd, 1900.

${ }^{29} \check{Z}_{i v o t}$ sv. Simeuna $i$ sv. Save, napisao Domentijan. Ed. by Đ. Daničić. Beograd, $\mathbf{r} 865$.

${ }^{30}$ In 1860 Đ. Daničić published Život svetoga Save and ascribed its authorship by mistake to Domentijan instead of to Teodosije.

${ }^{31}$ Published by Daničić, Životi kraleva i arhiepiskopa srpskih. Napisao arhiepiskop Danilo i drugi, Zagreb, I 866.

${ }^{32}$ Ed. by Ivan Kukulević (Bulgarian version) in Arkiv za povesnicu jugoslovenksu, IV (I857), I-29, and J. Šafařik (Serb version) in Glasnik srpskog učenog društva, XI (1859), 35 sq. 
by Domentijan in particular appears to him to be a witness "of the striking intelligence and the broad culture" of this writer; "it is one of the most precious jewels of the entire earlier Slav literature." ${ }^{33}$ He places it far above the revision made by Teodosije, who, according to Šafařik, has disfigured Domentijan's work. Daničić however has made the observation when publishing the two, that there is to be noticed no great difference, and Jagic maintained that the spun-out narrative of Domentijan is actually more lacking in facts than the biography of Nemańa by Stefan Prvovenčani. Domentijan is a garrulous monk who turned into rhythmic phrases the narrative of Stefan; the revision of Teodosije, if one studies it with care, bears witness to a greater degree of taste, and he varies less often from the account of Stefan, than does Domentijan. ${ }^{34}$

Among the works not produced in monasteries, and of which the subject may be considered more truly national, it is well to note two, which are highly interesting and unique in their way, Zakon Vinodolski (the Law of Vinodol) and Zakonik Stefana Dušana (the Code of Stefan Dušan). The Law of Vinodol was written in $\mathbf{2} 288$ in Novi, a city on the Croatian seacoast. ${ }^{35}$ It is a collection of older statutes and characterizes well those people for whom it was composed. The Codex of Stefan Dušan was accepted by the two Parliaments (Sabor, Congress) of 1349 and I354. Like a great number of other legislative documents of the Middle Ages the Zakonik is not a product of a single thought; the entire nation, at least the entire political nation, collaborated in it. The Code of Dušan established the authority of law and put an end to the arbitrary power of the nobles. However, its main importance lies in the fact that it permits us an insight in to the

33 "Eine der Hauptzierden der gesammten ältern slavischen Literatur." (P. J. Šafařík, Geschichte der serbischen Literatur, Abt. I, 230 f., I865).

${ }^{34}$ See V. Jagić, Historija kńiževnosti, I' (I 867), ch. VI, sec. 3-4.

${ }^{35}$ Vinodol in the 13th century was a district between Seń (Zengg) and Reka (Fiume), ruled by the Croatian princes Frankopans. The Zakon Vinodolski was published with introduction by A. Mažuranić, Kolo, III (1843), and by Fr. Rački in the Monumenta historico-iuridica Slavorum meridionalum, IV (1890). Another text with Russian version is by V. Jagić, Petrograd, r88o. A French translation, La loi du Vinodol, is by Jules Preux, Paris, 1897. 
life and the degree of civilization to which the Southern Slavs of that time, the most brilliant of their whole history, had attained, somewhat as the Russian Pravda of Jaroslav shows the degree of civilization of the Eastern Slavs. ${ }^{36}$

${ }^{36}$ Dušan's Codex has been published several times. The best editions are by F. Miklošić, Lex Stefani Dušani (1856), and by S. Novaković, Zakonik Stefana Dušana, 2 ed. 1898 . The interpretations of the Code are by N. Krstić, Glasnik srpskog učenog društva, VI (1854), VII (1855) and C. Jireček, "Das Gesetzbuch des serbischen Caren Stephan Dušan," Archiv f. slav. Philol. XXII (1900), pp. I4t-214. 


\title{
SECOND PERIOD
}

\author{
THE AGE OF RENAISSANCE
}

\section{CHAPTER III}

\section{REPUBLIC OF DUBROVNIK AND THE RENAISSANCE}

While the Orthodox Serb writers were following the paths laid out by the earlier authors, and among the Croatians of the West, Glagolitic literature was becoming dominated more and more by Catholicism, there grew up, among the Serbo-Croats of the Adriatic littoral toward the close of the I5th century a literary movement which is unique in early Slavonic literature. Formed by particular historic circumstances, a poetical school of the most remarkable talent budded forth, with its center at Dubrovnik (Ragusa) and its language the pure popular dialect. ${ }^{1}$

During more than two centuries (15th-17th) this new movement threw its bright rays towards the north, east and south. The history of the South Slav world does not offer anything to compare in intellectual intensity with this phenomenon. The Serbs or Croats from Dalmatia took up their residence at Venice and there were a number of ancient Slavic families in that celebrated republic. Politics, commerce and religion drew these two countries together, and made openings for the Italian Rinascimento to widen its scope. The science, faith, art, institutions, customs and usages of a polished and refined society gained a rapid triumph. The results moreover were so rich in content that there gradually started under the Latin influence a well maintained and steady current of production. This movement known in history as the Revival

1 The word Dubrovnik derives its meaning probably from $d u b$ (oak), or dubrava (oak-wood) which at one time covered the hills where the present city is situated. C Cf. L. Leger, "La République de Raguse," Revue des sciences politiques, XL (1918), p. 42, and Sir J. G. Wilkinson, Dalmatia and Montenegro, I (I848), ch. V, p. 277. 
of Learning or Renaissance, fired to a high pitch the little republic, which became the Mecca of Jugoslav intellectual life. The easy communication among the free republics, and the commerce which had developed the wealth of the country and enlarged the mental capacity of the population, were in direct contrast to the dire despotism and the civil wars from which Serbia was suffering at the time of the Turkish invasion. ${ }^{2}$

Situated on a craggy peninsula, the territory of Dubrovnik was too small and in part too sterile to provide sufficient foodstuffs for the population. Consequently it was upon trade and industry that the citizens had to depend for their means of livelihood. Trade, both sea-borne and overland, received a great additional impetus from the extension of Venetian traffic and from the increasing civilization of the Slavonic States. At Ragusa, Venice, Florence, Rome, and elsewhere in Italy, the aristocracy as well as the middle classes were interested in trade. We find members of all the noble families in the Ragusan settlements in Serbia, Bosnia and Albania, and no nobleman disdained to travel overseas with his own goods. Members of noble families engaged in trade were constantly making voyages on their own ships, and later they were employed as scribani. ${ }^{3}$ No one could be a scribanus unless he belonged to the Ragusan nobility.

The Ragusan vessels were found in every part of the Mediterranean Sea. From the commercial provisions contained in the various treaties between Ragusa and Venice, we

${ }^{2}$ The City (later Republic) of Ragusa was founded in the 7 th century by refugees from Epidaurum (now Captat). During the I $3^{\text {th }}$ century it acquired through trade and crafty diplomacy, lordship over a territory of some $75^{\circ}$ square miles, extending from the shores of the Boka Kotorska to the mouth of the Neretva, including the neighboring islands. It maintained its independence until $\mathrm{I} 808$, when, with the rest of Dalmatia, it was annexed to the lllyrian Kingdom (as a French possession). In I814 it passed to Austria, and in 1918 was united with its mother country, Jugoslavia. See J. Cvijić, La Peninsule Balkanique (1918), livre II, chap. VIII, p. 359, and L. Vojnović, Pad Dubrovnika, I-II, Zagreb, I9o8.

s Scribanus (Serb. pisar) is an officer employed by the nobleman (vlastelin) or magistrate. 
learn that the former traded with all parts of the Eastern Roman Empire, Syria, Egypt, Tunis, Barbary, Italy and Spain. ${ }^{4}$ At Constantinople, the privilege granted by the Comneni were renewed by the Latin Emperors Baldwin I and Henry. The Ragusans traded especially with the Morea, and the feudal duchy of Klarentza (Cyllene, Ital. Chiarenza) or Clarence, ${ }^{5}$ bringing silk to Ancona (Slav. Jakin) and other parts of Italy. At the same time they kept up their connection with the Greek princes who held sway over the fragments of the Byzantine Empire, namely, the Emperors of Nicaea and Trebizond and the despots of Epirus. ${ }^{6}$ When the Byzantine Empire was re-established in $126 \mathrm{I}$, all the exemptions and privileges were re-confirmed, first by Michael Palaeologus, and later, in 1322 , by Andronicus II. ${ }^{7}$

Other countries with which Dubrovnik had commercial intercourse were Bulgaria, Serbia, Bosnia and Hungary. In the early days of the second Bulgarian Empire (I2th century), the Venetians could not trade with it, as they supported the Latin Empire at Constantinople in withstanding the Bulgarian invasions. The Genoese were equally cut off because the Venetians excluded them from the Bosporus. The field therefore lay open to the Ragusans alone and they were favorably received by the Tsar Assen II (I2I8-I24I), who called them his "trusted beloved guests." 8 With Bosnia

4 C. Mijatović, a Serbian historian, asserts that after the fall of the Serbian State, viz., in the 17 th and 18 th centuries, Ragusa traded with America, and that some of its citizens came to power and influence in Spain and Mexico. See Glasnik srp. uč. druš. XXXIII (I 872), p. 226.

${ }^{5}$ Whence the title of the English Duke of Clarence was derived. See V. de Saint-Martin, Nouveau dictionnaıre de géographie universelle, I (I879), p. 749 .

${ }^{6}$ After the capture of Constantinople by the crusaders, Epirus continued to hold out against their arms, and was ruled by the despots Michael I (who died in 1214), Manuel (1214-124I), and Michael II (124I-127I), all of whom granted valuable privileges to the Ragusans. See G. L. F. Tafel and G. M. Thomas, "Griechische Original-Urkunden zur Geschichte des Freistaates Ragusa," in the Sitzungsberichte der Wien. Akad. der Wissenschaften; Philos.-hist. Klasse, Bd. VI (I85I), Hft. IV, 507 sq.

7 W. Heyd, "Histoire du commerce du Levant au moyen-âge," I (I885), p. 475 .

${ }^{8}$ Vsevernii lubovnii goste. See Fr. Miklošić, Monumenta serbica (1858), VII, p. 3 . 
and Serbia the Dalmatian trade became extremely active. In I35I according to Cerva (Crević), the Serbian emperor, Dušan, established an embassy at Dubrovnik. He founded there a large library filled with Greek and Latin books, and sent capable young men to study literary and humanistic sciences. ${ }^{9}$ Three years later Dušan himself visited Dubrovnik, ${ }^{10}$ and granted to the Ragusans concessions to exploit Serbian mines which were a source of considerable revenue to the State. The mines of Illyria were well known even in the Roman times. They were abandoned during the barbarian inroads, and it was not until the 12 th and I 3 th centuries, at the time of the rise of the Serb States, that the industry revived. Wonderful tales were told by medieval travelers of the golden splendor and richness of the Balkan mines and cities. As late as 1453 the Byzantine historian Kritoboulos of Imbros, speaking about the expedition of the Sultan Mohammed II (whose secretary he was) against George Branković, asserted that Serbia was a very fertile land and had all kinds of production in abundance. But the characteristic in which she surpassed other countries was her plentiful possession of gold and silver; everywhere one could dig he found large deposits of the precious metals in great quantities and even better than those in the Indies. ${ }^{11}$ The Serbian kings Stefan Uroš I (I243-I276)

- Primarios et ad litterarum studia aptiores suae gentis juvenes. Cit. by V. Jagić, Rad jug. akad. IX (1869), p. 206.

${ }^{10}$ Sir J. G. Wilkinson, Dalmatia and Montenegro, p. 3I4. Leopold Ranke assumes that Dušan visited Ragusa in 1347 , where he was received with European honors, and was acknowledged as its protector. Sämmtliche Werke, Bd. XLIII-XI.IV (1879), p. Io.

11 La terre (i.e., Serbie) y est rès fertile et capable de tout produire, en abondance, aussi bien en céréales qu'en arbres. Elle a aussi des troupeaux, c'est-a-dire des brebis, des porcs, des vaches et de beaux chevaux en grande abondance, et beaucoup d'autres a nimaux mangeables et utiles, apprivoisés et sauvages; elle en offre des races distinguées et produit tout ce qu'il faut pour leur nourriture. Mais ce qui forme son plus grand bien et ce par quoi elle surpasse de beaucoup toutes les autres terres, c'est qu'elle offre, comme d'une fontaine, de l'or et de l'argent, et partout oǹ l'on creuse se présentent des éjections d'or et d'argent en grand nombre et très belles, meilleures même que celles Indes. (Critoboulos, Vie de Mahomet II, livre II, par. 303I, traduit par le Dr. Ph. A. Déthiero, Monumenta hung. historica.Scriptores, XXI, Buda-Pest, 1866?) 
and his son Uroš II Milutin (I282-I32I) summoned German miners from Transylvania, called Saxons (Slav. Sasi), so as to benefit by their skill, but they employed many Ragusans also. The ore was extracted from galleries and shafts, many of which are still in existence. The refining of the metal was carried on at Ragusa or Venice.

Gold, silver, copper, lead, and iron were the chief products of the mines of Bosnia and Serbia. Gold, of which the earliest mention is in 1253, was found chiefly in the Novo Brdo (Novus Mons), now only ruins, between Priština and Vrańe, but at that time the largest city in the interior of the Balkan Peninsula. It was said in old chronicles that this city yielded about 200,000 ducats per year. Other principal mining centers were in Bosnia: Kreševo, Fojnica, Srebrenica, and Zvornik; in Serbia, besides Novo Brdo: Rudnik, Krupań, Kučevo, and Kopaonik; in Zeta (Montenegro): Brskovo or Brescoa. ${ }^{12}$ At the end of the $\mathrm{r} 3$ th century in Brskovo there was a mint, where the grossi de Brescoa were coined. The kings of Serbia (Rascia) beginning with Stefan Uroš I, struck their own coins in imitation of the Venetian ducats, but with considerable amount of debased metal, whence Dante's allusion (Paradiso, XIX, vv. I39-I4I):

\section{E quel de Portogalo e di Norvegia \\ li si conosceranno e quel di Rascia, che male aggiusta il conio di Vinegia... \\ And he of Portugal and of Norway shall be known, and he of Rascia, who counterfeited ill the coin of Venice. ${ }^{13}$}

12 A very elaborate and interesting account of the Ragusan trade and the Serbian mines in the Middle Ages is given by C. J. Jireček, "Die Handelsstrassen und Bergwerke von Serbien und Bosnien des Mittelalters" (I879), pp. $4 \mathrm{I}-58$.

${ }^{13}$ It is historical fact that the Venetian Government on Oct. 29, 1282, pronounced these coins false and gave an order to destroy them in all those Adriatic cities which were under its protectorate. "Die vigesima nona octobris capta fuit pars: quod occasione destruendi dennarios grossos de Brescoa . . ." (Monumenta spectantia hist. Slav. merid., Listine, I, I868, p. 133.) Although Dante was not flagello dei principi (the scourge of princes) as was his contemporary P. Aretino, he undoubtedly was inclined to the republican form of government, hence his stigmatization of a Serbian king as falsifier is easy to understand, but why the Venetian Government 
In Brskovo as well as in other mining districts the Ragusans had their colonies or settlements. At the head of the colony were the consul and two judges, usually noblemen appointed by the Republic. At the Royal Court in Skople (then the Serbian capital) resided an ambassador in whose charge were all the Ragusan settlements in Serbia.

Communication between Ragusa and the settlements in the interior was carried on by means of couriers. ${ }^{14}$ These couriers carried official correspondence from the Republic to the ambassadors and consuls, and legal notices, writs, reports of judicial proceedings, etc., to the Ragusan traders. They were not allowed to convey private correspondence, which was usually sent by caravan, or in the case of the chief merchants by their own special messengers, save on the return journey. ${ }^{15}$ The time employed by these caravans and messengers was usually ten days from Ragusa to Skople, seventeen to Sofia, and twenty-five to Constantinople. The official correspondence to the various representatives in the Near East is preserved in the archives of Dubrovnik in 138 volumes, under the heading of Lettere e Commissioni di Levante.

\section{II}

The traffic and trade carried on with the Byzantine, Italian and Slavonic States proved to be a source of great public and private wealth. The Ragusan merchants succeeded in making

issued such a denunciatory decree is not clear. All Serb coins of that time bear the effigies of the Serbian kings and Serbian inscriptions. The discrimination of these grossi one may see in the figures given by Philalethes in his translation of Dante Alghieri's Götliche Comödie (1866), p. 247, and in the collection of old Serbian coins by Janko Šafařik, Glasnik srpskog učenog društva, III (I85I), pp. $191 s q$.

${ }^{14}$ Lat. cursores, It. corier, Serb. listonoše, kñižnici or kniigonoše.

15 The Ragusan caravans (turma) consisted chiefly of horses and were under the charge of Vlach drovers. These Vlachs or Rumans of the Balkans were nearly all shepherds and cattle-drovers, with markedly nomadic habits. There are hardly any distinctive traces of them to be found now in Dalmatia, save in the name Morlacchi (Maurovlachs) given to the Slavs generally by ignorant Italians of the coast towns. In Macedonia, however, the Kutso-Vlachs (Cincari, Tsintsari, or Zinzari) are numerous. Their language belongs to the Neo-Latin group and they still ply the trade of wandering merchants and inn-keepers. (Cf. Jireček, op. cit. pp. 60-6r.) 
their port a real emporium of Eastern commerce. They accumulated large fortunes by intelligent management, sagacity and indefatigable industry. The proceeds obtained from their trade and industry were used for the promotion of literature and the arts of refinement. The literary treasures of ancient Greece and Rome were collected in libraries for public use. The city itself was beautified by the erection of magnificent buildings: churches, museums, and picturegalleries which still attract visitors from every land. Most of these edifices were built in the Byzantine and Gothic styles, but many of them also have original Slavonic features. As the Dalmatians of the maritime cities came into contact with the nations of Eastern and Western Europe, they imitated first Byzance and later Italy and Spain. The Byzantine influence in Ragusa and notably in Serbia, Macedonia and Croatia can be traced in art and literature as late as the 12 th century. ${ }^{16}$ After that time the Latin civilization prevailed not only in literature but also in architecture, painting, and sculpture. ${ }^{17}$

It is not difficult to explain why the Latin civilization mastered Ragusa. Young Dalmatians went to the neighboring peninsula to finish their studies, and an especially large number were gathered at the University of Padua. To Italy penetrated the western European customs, and the works which marked the end of the Middle Ages. Latin literature, which persisted in spite of the protest of the church and its doctrines, had already been cultivated with some success in Dalmatia where it had become, so to speak, naturalized. There Provençal poetry had been also known for some time-that cult of love songs and admiration for women or "divine worship of beauty." 18 An effect of the Renaissance was to reinstate the ancients and to create the inspiration for the study of the

${ }^{16}$ Cf. M. Dimitrijević, "L'Architecture religieuse en Vieille Serbie et en Macedoine." La revue slave, I (1905), p. $4 \mathrm{I} f$.

${ }_{17}$ See T. G. Jackson, Dalmatia, II (I887), p. $204 f_{\text {. }}$; also his article "Serbian Church Architecture" in South Slav Monuments, ed. by M. I. Pupin, v. I (1918), p. 7 sq.

${ }^{18} \mathrm{On}$ the subject of idealization of women in the period of the Renaissance, see the study of Prof. J. B. Fletcher, The Religion of Beauty in Woman, New York, I9I I. 
classical works. In a word, the literary and scientific influences which operated in Italy, were really transferred to the other side of the Adriatic. What Cicero once said about Greek and Latin literature, artissimo vinculo coniuguntur atque associantur, may be said even more truly of the Italian and Ragusan literatures. This parallelism between Italian and Dalmatian letters lasted as long as the Dalmatian literature itself endured; it commenced by considering the works of the ancients, the religion of classical antiquity, and admiration for Boccaccio and Petrarch; it finished by imitating Giambattista Guarini and Metastasio. Dalmatian writers were successful in all the directions towards which the Renaissance had inclined Italy: epic poetry, lyrics and the drama. ${ }^{19}$ It was not only exterior conditions of literary development which provoked curious likenesses, but the social position of the writers as well. Authors were accustomed to exercise a certain authority, gathering around them a little group of friends and disciples to inspire with their spirit.

This flowering was in fact a very peculiar and exceedingly odd event. A little republic whose population did not surpass a few dozen thousands of inhabitants, produced from the end of the $15^{\text {th }}$ century a relatively prodigious number of writers and savants, and a great majority of them of superior merit. Many states, and not the least powerful, would be incapable of producing illuminated books such as these authors illustrated. Although the position which this culture occupied, halfway between Italy and Byzance was without doubt a very favorable one, that would not suffice to explain fully such a brilliant movement, and it is necessary to reckon with the latent fund of national forces which this literature kept in reserve. The Renaissance moreover did not come from Italy alone. The Greeks contributed a large part to the Revival of Learning. After the fall of Constantinople in 1453, many Byzantines sought refuge in western countries, and some retired to Dubrovnik. There lived Demetrius Chalcondylas, E. Marulus,

\footnotetext{
19. An essay of the Ragusan drama, its sources and imitations, was made under the intelligent scrutiny of A. Pavić, Historija dubrovačke drame $(187 \mathrm{I})$. See also W. Creizenach, "Das serbo-croatische Drama in Dalmatien" in his work Geschichte des neueren Dramas, II (190I), pp. 506-526.
} 
J. Lascaris, and several others, celebrated over all Europe for their learning. ${ }^{20}$ After their arrival, schools for the study of the ancients were established and carried on. Of those Dalmatian students who flocked to the courses of study offered at the schools and universities of the neighboring peninsula, many later became known outside of their country and obtained European reputations. From Dubrovnik came Ivan Stojkovic (1395-1443), one of the most celebrated theologians of the I5th century, ${ }^{21}$ and Ilija Crević or Cerva (1463-I520), a crowned poet-laureate at the Quirinal in his 22 nd year. ${ }^{22}$ In the annals of art the name of Dubrovnik was not less glorious, and it would be easy to draw up a long roll of celebrities.

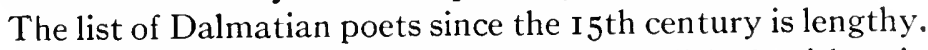
A small part of their work has been published, either in past centuries or in our own day, and that only since interest has arisen in this history. Mention of the manuscripts is scattered through various Dalmatian biographies, and in the great collections of different European states. We shall only stop to consider the best known authors, who are regarded in Jugoslav literature as classical. ${ }^{23}$

${ }^{20}$ Vid. Talvi, "Historical View of the Languages and Literature of the Slavic Nations" (1850), p. 128.

${ }^{21} C f$. P. Matković, "Prilozi k trgovačko-političkoj historiji republike dubrovačke," Rad jug. akad. VII (1869), p. 235.

${ }^{22}$ See C. Jireček, Archiv f. slav. Philologie, XIX (1 897), pp. 45 ff.

${ }^{23}$ For the sources of information regarding the Ragusan Renaissance and foreign influences, see V. Lamanskij, "Nacionalnosti italijanskaja i slavjanskaja v političeskom i literaturnom otnošenijah" (I865); F. Rački, "Prilozi za povest humanizma i renaissance u Dubrovniku," Rad, LXXIV (1885); A. Pavić, "Prilog k historiji dubrovačke hrvatske kńiževnosti," Ibid. XXXI (1875); S. Luubić, "O odnošajah među Dubrovčani i Mlletčani," Ibid. V (1868); Iv. Kasumović, "Utecaj grčkih i rimskih pesnika na dubrovačku liričku poeziju," Ibid. ICC (1913), CCI (1914), CCIII (19I4), CCV (1914); M. Korelin, "Rannyj italjanskij gumanizm i ego istoriografija" (I892); M. Medini, Povest hrvatske kńi ̌evnosti u Dalmaciji i Dubrorniku, vol. I, Zagreb, 1902. 


\section{CHAPTER IV}

THE POETS OF THE I 5TH CENTURY

I

One of the precursors of the Ragusan poets was Siško Mencetic (I457-I527). He had an especial talent for composing those love songs which the troubadours and their joglars brought to the world. The Provençal school had declined since the end of the $\mathbf{1} 3$ th century, but its influence reigned for a long time in the palace of Alphonse $\mathrm{V}$ at Milan, where that king spent his exile. In Italy Petrarch was the most illustrious representative of this conventional lyricism, and he had many imitators. As has been pointed out, Ragusa had too extended a commerce and too intimate relationships with distant countries to remain untouched by foreign customs and civilizations. Provençal poetry was not slow in penetrating there. Jagic by a comparison of the poems of Petrarch and his disciples (Petrarchists) with those of the Dalmatian writers has shown the influence which the poetic theory of love has exerted upon the Dubrovnik school, the theory as conceived by the Provençal singers. ${ }^{1}$ In the writings of Menčetić love is a subject which occurs again and again, and his Pesni Luvezne (Love Poems) form a veritable "Slavonic Canzoniere," in the Provençal-Italo-Castilian style. The prevailing characteristics of these poems are exaggeration and hyperbolism in emotion and expression. The poet sometimes repeats the same idea varied by allusions and wit, giving to his verses a gem-like form, as an acrostic of his name or the names of his heroines. The motifs of his chansons d'amour are taken from Petrarch, whom he greatly admired, and very often one can find entire stanzas translated from him. The verse is Alexandrine, with rhyme on the caesura, and contains twelve syllables.

The contemporary and coadjutor of Menčetić was Đore Držić (d. 1510). Subsequent writers held these two poets in

${ }^{1}$ See V. Jagić, "Trubaduri i najstariji hrvatski lirici," Rad jug. akad., IX (I 869), pp. 2 I 5 sq. 
high esteem and regard them as the Dioscuri. Ignat Đordic, a Dalmatian biographer, compared them to Petrarch and Boccaccio. Ranina praised them for having been the first to make known the poetry of their country. Although they knew Italian very well, they did not wish to work in a foreign field already overdone. They wrote in their own national language and became the glory of their people. In their works, it is true, there is nothing which recalls actual life; but in Italy this sort of poetry was as artificial and conventional; it was merely a kind of writing exercise. ${ }^{2}$ Nevertheless the great merit of the poets from Ragusa lay in their efforts to develop the Jugoslav language. Each of their works makes a step in advance in the use of the Serbian or Croatian dialect, purifying and ennobling it. Ranina ${ }^{3}$ rendered the sonorous Slav languages their due by stating that they offered no less potentialities than Italian and Latin. Furthermore it seems that real popular poetry was not held in contempt by the early writers. In some of their poems one finds among other things, certain verses which by their character and the sentiment which they inspire, are singularly like the national pesma (song), if indeed it is not that. From this point of view there is a remarkable progress from Menčetić-Držić and their immediate successors. They took a real interest in popular poetry, in searching for and imitating authentic creative works. ${ }^{4}$

\section{II}

A short time after the above mentioned amorists came Hannibal Lucić (c. I485-I553). He also wrote love songs, but more especially a drama, Robina (Slave-girl), the theme of which was taken from the Croatian wars against the Turks.

${ }^{2}$ As people fell in love by fashion so they composed songs which did not always correspond to their real feelings. Cf. Ivan Milčetić, "O poslanicama u dubrovačko-dalmatinskoj periodi hrvatske literature" (I882), p. 54.

${ }^{3}$ See infra.

4 The poems of Menčetić and Držić have been edited by V. Jagić, Starı pisci hrvatski, v. II (1870). For a good account of these two lyricists, see also V. Jagić, "Die Acrosticha bei Menčetić u. Držić," Archiv f. slav. Phil. V (I88I), 87 sq.; C. Jireček, “Der Ragus. Dichter Š. Menčetić," Ibid. XIX (1897), pp. 22-89, and "Beiträge zur ragusanischen Literaturgeschichte," Id. Ibid. XXI (I899), pp. 399-542. 
One of the most curious of his songs is that which was composed $U$ pohvalu gradu Dubrovniku (In honor of the city of Ragusa), and which pulses with the sincere and emotional respect which this free Republic inspired abroad:

Moj pisni zbrojiti nikakor ni moci sve kraje, čestiti Dubrovnik gdi opći.

Kroz gore, kroz luge, po svitu svej miče trgovce brez druge zabave ni prič;

po stranah, ke gleda sunce na daleče, $i$ koje prik reda i s redom ke peče,

sve trge primaju, mirno ke donosi, $i$ ke oni daju, on mirno odnosi;

pače još tko hodi po svitu, nastoji svak, da kako godi ime mu posvoji.

i da se povidi négov, premda nije, za neka svak vidi dobro ga svudije.

Dostojan je svudi ovi grad da slove da ga Bog $i$ ludi vazda blagoslove.

My songs cannot enumerate all the lands with which the famous Ragusa communicates.

Over mountains and through forests, all the world over, does she send merchants without let or hindrance;

Through lands where the sun shines from afar, where it burns moderately and blazes overmuch;

All receive the wares which they peacefully bring, and what they give, she peacefully carries away;

And still there are in the world those who endeavor by all means to appropriate her name,

And declare her their own city, though she is not, for everybody knows that good is good everywhere.

Worthy is the city that she should everywhere be praised that God and men should bless her.

However, the patriotism of this poet did not limit itself to the walls of Dubrovnik. It was a true Slavic soul which beat 
in his bosom; he wept at the thought of his people suffering under the Turkish yoke; he implored the help of Providence and blushed to think that the Slavs were not protected by others, that they were brothers abandoned by brothers. The Robina of Lucic is the first original attempt at drama, properly speaking. It treats of a girl of noble family who is abducted by the Turks and who is put up to be affianced in the market-place, where she is ransomed by a young hero, Ban Derenčin, and set at liberty. Such a subject would readily lend itself to heated outbursts against the Musulmans. However in all the writings for the theatre at Dubrovnik the hatred of the Christians against the infidels, the struggle of the Cross against the Crescent, was never allowed to be openly displayed. This shows the pacific and prudent policy of the Dubrovnik Republic; under her hands much was undertaken against the Turks, but she had too much wisdom to commit any overt act of provocation.

The fourth of the renowned Dalmatian poets of this period was Mavro Vetranić (I482-1576). Son of an old patrician family, he entered the Benedictine order and later became superior of a very important monastery. Because of a difference with one of the ecclesiastics, he retired to a modest cloister in an adjoining island and lived as a veritable hermit. He never came to the point of giving up his works, or abandoning his relationships with his friends, his disciples or the contemporary writers. After his death a number of songs and elegies in Croatian, Italian and Latin were composed in his honor. He left a collection of mysteries: Posvetilište Abramovo (The Sacrifice of Abraham), Uskrsnuće Isukrstovo (The Resurrection of Christ), and Suzana Čista (Susanna the Chaste). His language is elegant and pure, his verse easy and pleasing. "The Sacrifice of Abraham" is certainly one of the best Bible-dramas and one of his chefs-d'œuvre. The personages are well presented and the situations treated with acknowledged skill. Certain details show that the author knew the popular songs and understood how to apply them. There is a very poignant poetic feeling in Sarah's grief over her son Isaac, and this recalls in a striking manner the charm of the Serbian naricańa (lamentations): 
O dragi moj sinče, dušice luvena, gizdavi jelenče od luga zelena!

tko mi te usplaši is majkom razdieli, što majku ne utaži, da grozno ne cvieli?

Orle zlatoperi, kamo si poletil? što majci zaperi u srce jadan stril?

Panne pozlatan, kud zajde po travi? jur ve je treti dan da majku ostavi.

Moj sivi sokole, mitaru priliepi, što majci na pole srdačce prociepi, Kragujče gizdavi, reci mi Boga radi u koj si dubravi loveći ostao sad?

Tko mi će lubiti tve lice pribilo i tebe bluditi vazamši na krilo?

O my cherished son, my little well-belovéd, my beautiful little deer of the green forest!

Who hast thee away from thy mother a-frighten'd, why didst thou not console mother from grim sobbing?

My golden-winged eagle, where hast thou flown? why pierced the heart of mother with poisoned arrow?

My golden peacock, where hast thou hidden in grass, and now three days is thy mother left all alone.

My own gray falcon, my ornamented nestling, why hast thou torn the heart of forsaken mother,

My gilded birdling, tell me in the name of God, into what forest wert thon lured by the chase?

Who will for me kiss thy white face and take thee to her bosom, oh my wandering son.

(Posvet. Abram. IV, 2.)

There is also a poem by Vetranić called Remeta (The Hermit) in which he describes with a charming grace the lonesome life on his Dalmatian island of St. Andrews. The diction is very vivid and realistic, with many metaphors and images. In his strange composition Putnik (The Pilgrim), Vetranić takes the reader over the mountains, the valleys and the solitary places of Dalmatia, and fills in his descriptions with historic narratives. This entire poem is a medley, a strange tissue of the most unrelated subjects. It is an allegory representing man in three stages: in sin, in repentance and in omniscience, somewhat similar to Dante's "Divine Comedy" and Komensky's "Labyrinth of the World." Besides Putnik, Vetranić has several other poems with didactic motifs. 


\section{CHAPTER V}

LYRICS AND DRAMA OF THE I6TH CENTURY

In the I6th century the Ragusan literature continued as in the preceding period. Taken as a whole the literature of this era reaches its zenith, especially in regard to poetry: lyric, epic and dramatic. But besides these forms of poetry there is a new one, poslanice (rhymed letters), usually written by one friend to another. In addition, there is a new form of dramatic poetry, pastirske igre (pastoral plays, Ital. pastorali). Tragic as well as comic plays (šalive igre) received due attention. The poets who have taken the lead in this creative movement are Andra Čubranović, Nikola Nalješković, Dinko Rańina, Dinko Zlatarić and Marin Držić.

\section{I}

Andra Čubranovic (fl. I535), a native of Dubrovnik, was a Dalmatian poet who did not belong to the nobility. Like the Italian artist Benvenuto Cellini, he was originally a goldsmith, but later deserted this craft and betook himself to that of the muses. The most distinctive and best known of his works is the Jedupka (literally the "Egyptian", Gypsy Woman) published for the first time in Venice (1599) and later in Dubrovnik. It is composed of seven parts or cantos, in which the Romany woman makes diverse predictions to six young ladies in the familiar fashion by telling them their secrets. Crević (Cerva), a noted Ragusan historian and critic describes the production of the Jedupka in this wise: The author was on one occasion following a young lady, the object of his affections, and urging his addresses, when she turned round and said scornfully: Quid porro Egyptius iste? (What does that gypsy want with me). The despised poet and lover took up the word of reproach and he wrote this poem. ${ }^{1}$ To the first five ladies the disguised gypsy predicts the usual good

${ }^{1}$ Quot. by L. Zore, Stari pisci hrvatski, VIII (1876), p. vi, Introd. 
fortune (dobru sreću), but to the sixth she expresses love and admiration, although the fair patrician is far removed in station above her "fortune-teller."

It seems very likely that Čubranović wrote his Jeđupka for carnival fêtes. The Italian carnival was never held without some special poetry, or small pieces for the theatre being composed. ${ }^{2}$ These sportive customs were to be found also on the eastern shores of the Adriatic. A number of Dalmatian writers, Čubranović among others, wrote these masquerades. The Jedupka is certainly one of this sort. We know for a fact that this piece was recited in public at Dubrornik in 1527 . Cubranović is very superior to his predecessors, notably in the purity of his language and the poetic charm of his narrative. His verses are light and vivid, and characterized by rare rhymes and many archaisms, which are really ornamentations of his poetry. According to Šafařík, the Jeđupka is a splendid flower in the garden of the Jugoslav muses. It was very popular in its time, and was imitated by other writers, perhaps because it was based on the happy idea of declaring love in allusions. For two or three centuries this poem was imitated, but none of the imitations equalled the original. ${ }^{3}$

Of Nikola Nalešković ( $5_{5} \mathrm{IO}_{-} \mathrm{I}_{5} 87$ ), a native of Dubrovnik, it is known that he was not only an author and poet, but a scientist as well. It is not generally realized that he attacked the system of Galileo, ${ }^{4}$ but his love songs and especially his comedies and pastorals, which he had performed in his friends' houses or on the public stage, live after him. His bucolics and his "commedie erudite" are imitations of the Italian, with the exception that his vilas (a kind of mischievous sprite) replace the ninfe (nymphs) of the Italian writers. He was the first who really gave a truly dramatic character to his compositions. The critics distinguish two kinds of pastorals, those of

2 Especially was this done in the days of the Medici, when much more attention was paid to the mascherate or balli in maschera (masked balls) than in modern times.

${ }^{3}$ One of the best studies on Cubranović and his Jeđupka is to be found in L. Zore, "O Jeđupci Andrije Čubranovića," Rad, XXVII (1874), pp. 5368. See also M. Medini, "Čubranović und seine Beziehungen zu der einheim. und der italien. Literatur," A rchiv f. slav. Phil. XXII (I900), 69-I06.

"In his work "Dialogo sulla sfera del mondo." Venice, I 579. 
Dubrovnik and those of the Island of Hvar. In both types the theme is the same, that of the love of a shepherd for a vila; yet some are idyls, some comedies, and some farces. His writings are strongly heightened with pastoral and Renaissance fancies, but somewhat languorous and overwrought. They bear evident marks of unequal workmanship, curtness alternating with redundance, and carelessness with elaboration. ${ }^{6}$ But his rhymed letters (about 40 in all), directed to Ragusan notabilities and his contemporaries, are emotional and full of melancholy tenderness. ${ }^{6}$ There is no doubt that Nalešković influenced his successors. Some of his poems and works have been lost; others are fragmentary, and many are more or less disfigured by corruptions and disarrangement. Thus the restoration and interpretation of this poet's works is one of peculiar delicacy and difficulty.

Another remarkable poet of the sixteenth century is Dinko Rańina (I556-I607). He was born of a well-to-do Ragusan family. Upon returning home from foreign countries, he took part in public affairs. He was made president of the republic seven times, and wrote extensively in Serbian (about $45^{\circ}$ poems) and Italian (about 30). He is the first of the Ragusan poets to introduce eclogues and elegies; yet love songs are the most important part of his work. The character of Rańina is reflected in his poems. He was a man of generous impulses and a gentle, unselfish disposition. His tenderness and Platonic love are enhanced by a refinement and delicacy which are rare among his predecessors of the I $5^{\text {th }}$ century. If he refers to the "shrewish Latin girl" Livia, he does it by way of warning and not in any petty spirit of triumph or revenge. Although he

${ }^{3}$ In the English literature Naleškovic has some common features with A. Pope (Pastorals and The Rape of the Lock), in Italian with A. Tassoni (La sechia rapita), in French with N. Boileau (Le lutrin) and J. Gresset (Lutrin vivant and Le siècle pastoral).

${ }^{6}$ Rhymed letters (Lat. epistola, Slav. poslanice) had in Ragusa relative literary value. Their value depended upon the persons by whon and to whom they were written, as well as upon the subject thereof. Vid. Ivan Milčetić, op. cit. p. 4 . 
may have been treated cruelly by his love, he does not invoke curses upon her head. He goes often to his Nika's grave, which is hung with garlands and wet with tears, and bemoans his fate to the remains there. Apart from his original poems, Rańina's contribution to posterity includes translations from Propertius, Tibullus, Catullus, Virgil and many good verses from the Greek poets: Theocritus, Maschus, Philemon and others. ${ }^{7}$

The ground covered by Ranina in reference to lyrics was later extended by Dinko Zlatarić (I558-1610). He was born at Dubrovnik, finished his studies at the University of Padua, and while still very young, being only twenty-three, was appointed rector of the University gymnasium (Almae Universitatis philosophorum et medicorum Patavini gymnasii rector dignissimus). After having remained for some time in various foreign countries, he returned home.

The poems of Zlataric consist of those published in Venice I597, Pesni u Smrt (Poems to Death), mostly epitaphs to his friends, and Pesni Razlike (Various Poems), dedicated to the Ragusan poetess, Zuzorić, a woman of singular beauty and varied accomplishments. In the society of this lady, Zlataric found the intellectual sympathy and encouragement which were essential for the development of his powers. His poems give a very clear image of the social life of Dubrovnik. They record the different stages of passion through which the poet passed, and show the strong feelings with which he was affected. Returning to his birthplace from Zagreb, the capital of Croatia, he lived as an equal with the men of the greatest intellectual activity and refinement, as well as of the highest social and political eminence.

Among his other works Zlatarić twice translated Tasso's celebrated pastoral play "Aminta" to which he gave the Slavonic name Lubmir. Later he also translated the Electra of Sophocles, and Ovid's Pyramus and Thisbe. ${ }^{8}$ Didactic

${ }^{7}$ For various details on Rańina's translations from Latin and Greek classics reference should be made to Fr. Maixner, "Prievodi Rańine Dinka iz latinskih i grčkih klasika," Rad jug. akad. LXX (1884), 196-222.

8 Taken from Metamorphoses (IV, 55-465). 
poetry occupied a large place in his writings as it did in that of Ranina. ${ }^{9}$

One of the greatest names among the Ragusan dramatists in the period of the Renaissance is Marin Držić (c. 1518-1567) who was born of a plebeian family in Dubrovnik. In Jugoslav literature this author is compared with Molière. We are not directly concerned here with his dramas, The Book of Jesus and Hecuba, which are religious and antiquated. He is more attractive in his Tirena and Đuho Krpeta, two allegorical plays glorifying love. In his Lubav Venere he reminds us of Shakespeare's "Venus and Adonis." To another genre belong the comedies Novela od Stanca (The Tale of Stanac), a sympathetic versified story with much local coloring, and Dundo Maroje, a five-act comedy written in prose. Dundo or čika (uncle) Maroje is father of a prodigal son, Maro, who spends his youthful days in luxurious Rome with a courtezan of the upper class. When the father comes to the city to see his son's business, the latter deceives him. In the meantime the father plays a trick upon the son and takes his borrowed merchandise back home with him. Characteristic comedies are Mande and particularly the Skup (Avarus), which was an imitation of the "Aulularia" of Plautus, the model of Molière's "L'Avare." Remarkable but not finished are the Arkulin, Pomet, and Pjerin. The last one is a "comedy of errors" and was based on the "Menaechmi" of Plautus and the "Andria" of Terence. $^{10}$

${ }^{9}$ The renderings of Zlataric from Tasso are more successful than those from Sophocles, although even here he is too liberal in Slavonizing the Italian proper names and changing the sense of whole verses. $C f$. A. Pavić, "Prilog k historiji dubrovačke hrvatske kńiževnosti," Rad jug. akad. XXXI (I875), p. I $48 f$.

${ }^{10}$ In regard to the origin and character of Držić's dramas, reference can be made to M. Šrepel, "Skup M. Držića prema Plautovoj Aululariji," Rad, XCIX (1890), I85ff.; P. Budmani, "Pjerin M. Držića," Ibid. CXLVIII (1902), 5I sq.; G. Polivka, "Der Geizige in Ragusa," Archiv f. d. Studium d. neueren Sprachen und Lit. (Braunschweig, I 888, pp. 433-42); V. Jagić, "Die Aulularia des Plautus in einer südslav. Umarbeitung aus der Mitte des XVI Jahrh." (Festschrift Johannes Vahlen, ch. XXXIII, pp. 6I 5 sqq. Berlin, 1900); P. Popović, "M. Držić i Molière," Iz kńiževnostı, Beograd, 1906. 


\section{III}

Among the "poetae minores" of the I5th and I6th centuries reference must be made to Marko Marulić (I450-1524) and Petar Hektorović (1487-1567). The former left two religious epics, Judith (I52I), one of the first printed books in Jugoslav literature, Susanna, and several translations (Catonis Distichia Moralis, M. Belcari's St. Panuzio, etc.); the latter wrote a poem, Ribane (Fishing), and gave new stamina to the old Jugoslav literature by including certain national songs (bugarštice), which he heard from popular bards. Stepan Gučetić (fl. I525) composed a parody, Derviš, of 50 sestines, a masterpiece of airiness and ingenuity. ${ }^{11}$ Nikola Dimitrović (d. I 553) gave us Seven Penitential Psalms (1549) and several religious odes called Pesni Duhovne (Spiritual Songs). His Pričice (Epigrams) and his rhymed epistles from Alexandria are characteristic because of their vigorous and realistic style. Petar Zoranić (1508-I550) is mentioned with his pastoral, Planine (The Mountains), and Marin Gazarević (c. I580-I623) with his dramas, Lu ubica, a pastoral play, and Prikazańe sv. Beatrice, Faustina i Simplicija bratje. ${ }^{12}$ Juraj Baraković (I 548-I628) wrote Vila Slovinka in thirteen cantos, including a folk song "Mother Margareta." We have from Brne (Barne or Bernando) Karnarutić (I553-I60o) Vazetje Sigeta Grada (The Capture of Sziget the City), the first epic poem in Croatian literature, ${ }^{13}$ and from his confrère, Antun Sasin (d. I640), the epic, Razboj od Turaka (The Destruction of the Turks). The latter wrote also two pastoral plays, Filida and Flora, and one farce, Malahna, all in the style and tone of the comedy of the time. ${ }^{14}$ Savo Bobalevic

${ }^{11}$ Appendini, Šafařik, Kukulević and Šurmin ascribe this poen to Gučetić, while I. A. Kaznačić, M. Rešetar, M. Medini, and P. Popović believe that its author is Stepan Đorđić (fl. 1630).

${ }_{12}$ Published by Jugoslav Academy in Starn pisci hrvatskı, XX (1893), pp. $219-237$.

${ }^{13}$ The first edition of this epic was published at Venice in 1584 . Velimir Gaj published a new edition with introduction and tumac (glossary) at Zagreb, i 866.

14 Vid. P. Popović, "Antun Sasin dubrovački pesnik XVI veka," Glas srpske akademije, XC (1912), pp. I-67. 
(1530-1585) is regarded as the Ragusan Anacreon; he is one of the founders of the Akademija Složnih (Accademia dei Concordi), a literary society to which, among others, belonged the poetess Cveta (Flora) Zuzoric (I 555-I600), the "Aspasia of Ragusa."

Satire was fostered in Dubrovnik particularly by Miho Bunić (d. 1590), who wrote among other things a macaronic poen against women, entitled Sedam Opačina (Seven Vices), and one drama, Jokasta, founded on the "Phoenissae" of Euripides. $^{15}$ Marin Burešić (c. I5IO-I562) is a didactic poet and the translator of Nanci Katonovi (Proverbia Catonis), published in 1562. Frano Lukarević (b. I530) left the Atamante A $^{16}$ and a pastoral, Verni Pastir (The Faithful Shepherd), both of these dramas patterned after Italian playwrights. Savko Gučetić (d. I603) is the author of the Dalida, which resembles Shakespeare's "Romeo and Juliet," and the Ariadna, which was adapted from the Italian writer Vincenzo Giusti.

${ }^{15}$ See A. Leskien, "Zur Jokasta des M. Bunić," Archiv f. slav. Philol. V (1 $88 \mathrm{I}), 628 \mathrm{sq}$.

${ }^{16}$ Cf. M. Rešetar, "Das original des Atamante," Ibid. XXIV (1902), pp. 205-209. 


\section{CHAPTER VI}

\section{GUNDULIĆ AND HIS TIMES}

In the succeeding ( $17^{\text {th }}$ ) century the Ragusan literature attained its greatest height. Lyrics, drama and epics are more developed than in the preceding century, especially epic poetry. The drama becomes ampler in quantity and more refined. The pastorals and comedies almost entirely disappear. Classicism is the basis of the literature of this time. It is interesting to note that poetry changes even in its external form; in the previous two centuries the verse was mostly of twelve syllables and here it is of eight. The classic representatives of this period are Ivan Gundulić, Junije Palmotić, and Ivan Bunić.

Ivan Gundulic (1588-I638) is the greatest epic poet of the Jugoslav littoral and was not unjustly styled rex Illyrici carminis, since he was the best representative of the golden age of Ragusan literature. He was born in Dubrovnik on the 8 th of January, 1588, of a prominent cultured family. His father was president of the Republic and gave him an excellent education. In I 609 he entered the civil service and later occupied high positions in the Republic as commissioner, justice and senator. He was married in 1628 and had three sons one of whom was also a poet. In I 622 Gundulić published Suze Sina Razmetnoga (The Tears of the Prodigal Son), an elegy on the well-known biblical theme, and in I628 his most original play, Dubravka, was acted at Ragusa with great success. With this beautiful pastoral Gundulic became the poet of freedom and patriotism. Of no less significance are his still extant dramas: Ariadna, Proserpina, Dianna, Armida, and his metrical tale, Lubavnik Sramežliv (The Bashful Lover). The last one is his only amatory poem and tells the old story of the timid lover who sent his declaration to his sweetheart in a billet-doux. Yet his principal claim for notice by posterity is his 
Osman, a masterpiece which his contemporaries declared immortal, and which remains today the honor of Jugoslav literature and the most remarkable work of the Ragusan period. Gundulić, it seems, sought a subject which, lending itself to the art of poetry, would glorify the Slavonic race and especially his beloved fatherland. Indeed, what more prolific and richly endowed motif could he have chosen than that of the war of I62I between Poland and Turkey, in which the Moslems received such a severe check in their invasion of Europe! His epos is composed in the Italian style of that time. It is clear that he wished to take for his models Ariosto and Tasso, particularly the latter. Other passages prove that the writer was inspired by Virgil, Horace, Ovid and Homer. The inevitable errors of the pseudo-classicism of the century are evident. But leaving aside some other colder imitations, the work of Gundulic is full of beauties of the first order. He carefully studied the events of which he wrote and the geography of the country through which he was to take his reader. He knew the history, not only of Poland and Dalmatia, but of all the Slavs and especially of the Southern Slavs, the richness of whose literature inspired in him an eloquent pride. He felt himself to be a Slav, and all the fibres of his being trembled at the thought of the decisive struggle in which Christians were engaged against Mohammedans, and the Slavs against the barbarians. This patriotism found its expression in magnificent descriptions of the romantic Balkan scenery at Kosovo, Marica, Smederevo, and Dubrovnik. Of the latter city he sings:

\author{
Ah, da bi u vik jakno sade \\ živio miran $i$ slobodan \\ Dubrovniče, bieli grade, \\ slavan svietu, nebu ugodan! . . . \\ Još sred usta luta zmaja, \\ i nokata biesna lava, \\ oko tebe s'oba kraja \\ slovinska je sva drăava. \\ Robovi su tvoji susedi, \\ teške sile svim gospode; \\ tre vladane samo siedi \\ na pristnlu od slobode. . .
}


Oh, mayst thou live as now thou dost, a-tune with freedom, peaceful town, thou castle white, thou heaven's trust, Dubrovnik, city of renown! . . .

Though still within the dragon's mouth, to fierce and fiery lions a mateyet round thee spreads from north to south the all-pervading Slavic state.

Neighbors to thee, the bondsmen are, oppressive violence grinds them allbeyond great powers near or far thou art our freedom's seneschal. . .

(Canto V1II, vv. 569 ff.)

To realize the epoch-making character of the Osman, it must be remembered that it was the first epic anticipating the unification of the Southern Slavs. It sings of the kings of the Nemana family, the bans of Bosnia and Croatia, with the same enthusiasm as it glorifies the patrons of Dubrovnik. The poet apostrophizes the heroism of Miloš Obilić, Marko Kralević and Herceg Stepan. He personifies George Branković with his twelve sons as the "Jugoslav Laocoon." According to his poetic imagination even Alexander the Great is a Serbian (Srblanin) because he ruled Macedonia, which later on was inherited and governed by the Serbians:

\section{$U$ pjesan se stavi odavna od Lesandra Srbjanina orh svih cârâ càra slavna. . .}

It was written in the song long ago of Alexander the Serbian a glorious emperor above all emperors. .

(Canto III, vv. 66-68.)

As Gundulić did not keep aloof from political life he was profoundly moved in the sphere of government, religion, morals and human feelings which were then changing the world. In uttering the enthusiasm of the hour, and all the new sensibilities that were stirring in his own heart, he had divined at the decisive turn of Slavdom what the future would disclose. He had more sympathy for the national ideals than any of the earlier Jugoslav writers. The effort of the preceding generation (Čubranovit, Vetranit, Sasin) to 
attain a mastery of form and of artistic execution had failed. It was left for this poet to bring diction and rhythm to as high a pitch of artistic perfection as had ever been attained before him. The structure and diction of the Osman is a large and varied instrument. The supremacy of this poet among all the poetic artists of his country is in that subtle fusion of the music and the meaning of language which touches the most secret springs of emotion. He evokes the emotions of reverence and of yearning for a higher spiritual life, and the sense of nobleness in human affairs. These and other qualities of his genius make him by universal acknowledgment the greatest literary artist which Dubrovnik produced. ${ }^{1}$

\section{II}

The contemporary of Gundulić was Junije Palmotić (16061657), who was also descended from a noble family of Dubrovnik. In his youth he began to compose verses in Latin, but Gundulić persuaded him to give up such sterile work. $\mathrm{He}$ then started to study with ardor the Jugoslav language. Be-

1 Gundulić wrote eighteen works, of which eleven were dramas. Most of them perished during the earthquake and fire of 1667 . His Osman in 20 cantos (in stanzas of four lines of eight feet) was printed for the first time in Ragusa in 1826 , but two cantos (XIV-NV) are lost. It is generally believed that the Ragusan Senate suppressed them from consideration for the Sultan, the protector of the Republic, those two songs having been violently anti-Turkish. They were replaced later by fine compositions of $P$. Sorkočević (1749-I 828) and Ivan Mažuranič (I 8 I $4-1$ 890). The best edition of the complete works of Gundulić was published by the Jugoslav Academy of Sciences and Arts (Stari pisci hriatski, vol. IX, Zagreb, I877). Important contributions to biography and textual criticism on Gundulić are contained in the following treatises: F. M. Appendini, "Memoria sulla vita e sugli scritti di Gian Francesco Gondola," Ragusa, 1827; A. Jensen, Gundulić und sein Osman, I9oo; M. Ban, "O Ivanu Gunduliću," Glas srpske akademije, IV (I888), pp. I-32; A. Pavić, "O kompoziciji Gundulićeva Osmana," Rad jug. akad. XXXII (1875), I04 ff.; L. Zore, "O kompoziciji Gundulićeva Osmana," Ibid., XXXIX (I877), i5 Iff.; "Alegorije u Gundulićevoj Osmanidi," Idem, Ibid. XCIV (I889), I 99 ff.; F. Marković, "Estetička ocena Gundulićeva Osmana," Ibid. XLVI, XLVII, L, LII (1879-80); R. Brandt, "Istoriko-literaturnij razbor poemi I. Gundulića Osmana," Kiev, I 889; M. Rešetar, "Die Metrik Gundulić's," Archiv f. slav. Philol. XXV (1903), 250 ff.; Ossip Makowej, "Beiträge zu den Quellen des Gundulićschen Osman," Ibid. XXVI (1904), 7I-100. 
cause at Dubrovnik the national dialect was changed by its mixture with Italian, he went to Bosnia where the Slav spirit had been kept most pure. There he applied his clever talent to many different things. But he did not prove himself capable of great originality in the choice of his subjects, although he was one of the most prolific writers in the Ragusan period.

Four of his important dramas are Pavlimir, Danica, Bisernica and Captislava. Narratives connected with the founding of Dubrovnik inspired his Pavlimir. This is a sort of Ragusan "Aeneid," Pavlimir corresponding to Aeneas. He comes from abroad, founds the city of Dubrovnik, marries the beautiful Margareta, whom he discovers there, and becomes otac slovenskog naroda (the father of the Slavonic people). The Danica is a dramatized episode from Ariosto's "Orlando Furioso" (IV-VI), transplanted and acclimatized to the Bosnian and Ragusan soil. Danica is the enslaved daughter of the Bosnian king, Ostoja. She was saved by the Ragusan knight Matijaš, who later became the ban of Croatia. Some motifs of this play are akin to Shakespeare's comedy "Much Ado About Nothing." Captislava is less historic and more fantastic; the chief rôles are played by ghosts and nymphs. Captislava (read: Tsāptislava) is the daughter of the King of Captat (Tsāptat or Epidaurum). She is in love with the Hungarian prince, Gradimir, but the father wants her to marry a Serbian prince. A nymph helps her in this cabal, and she elopes with the Hungarian prince, while her sister marries the Serbian prince. ${ }^{2}$ The Bisernica is still more fantastic. It is virtually the continuation of the Captislava, and almost all important rôles are played by vilenice (nymphs) and vilenici (dragons).

In addition to these four dramas, in which Palmotic celebrated the exploits of Slavic heroes, he wrote several imitations based on Latin and Italian sources. Thus the material for his Alčina was taken from Ariosto, and for the Armida from Tasso. The mythological play Atalanta is based on Ovid's "Metamorphoses" (bk. X), and the Natecane Ujača $i$

2 On the text of this drama, see the article of R. Brandt, "Prinos k tekstu Palmotićeve Captislave," in the Grada za povest kńiževnosti hrvatske, IV ( 1904$)$, pp. I50 ff. 
Ulisa (The Racing of Ajax and Ulysses) on the same work (bk. XIII). However, Ovid was the model not only for these two dramas, but for a third, Elena Ugrablena (The Raped Helen). His Lavinia and Došastje od Enee k Ankizu (The Coming of Aeneas to Anchises) are two dramatic compositions of which the subject-matter was borrowed from Virgil's "Aeneid." To this category of dramas belong also the Achilles, following the "Achilleis" of P. Statius, and the tragi-comedy, Hypsipyle, relating to episodes in the "Argonautica" of V. Flaccus.

Upon the whole, Palmotic was unquestionably a poetic and dramatic creative force, but he was not a genius who was able to reject the traditional form and create a new one. He managed to get more from the old materials than any one else before him, and in certain directions he even added something new. His biographers say that he was a marvellous improvisator, and a master of all the resources of the harmonious Serbian language. His songs and satires were quite the rage in society. While one person was singing a verse, he was composing another, more entertaining and gay. His early education had left deep traces on him. Religious feeling inspired his earliest work Christiada and most of his lyric poems. The Christiada was printed in I670. It is an epic of twenty-four cantos. Its content is a mixture of Christian traditions and remnants of Greek, Latin and Slavic mythology. It was patently remodelled on the similar work of Marco Vida (an Italian poet of the sixteenth century) with a large number of remaniements or rehandlings. In Jugoslav letters this poem has about the same claim as Klopstock's "Messias" in German and Milton's "Paradise Lost" in English literature. ${ }^{3}$

One of the best Ragusan lyric poets of the $I 7$ th century is Ivan Bunić (d. I658). There are few documents dealing with his life. It is known that he was a nobleman who occupied

${ }^{3}$ The complete works of Palmotic have been edited by the Jugoslav Academy (Stari pisci hrvatski, vols. XII-XIV, XIX, Zagreb, I882-4, 1892). A summary bearing on the text and interpretation of his dramas and poems is given by M. Rešetar, "Zur Textkritik von Palmotić's Dramen," Archiv f. slav. Philol. XV (I893), 38 I ff. "Zur ersten Ausgabe des Christias des J. Palmotić," Id. Ibid. XXIV (1902), 209 ff.; A. Pavić, "Junije Palmotić," Rad jugosl. akad. LXVIII (I883), LXX (I884); Ivan Kasumović, "Izvori Palmotićevih drama Ipsipile i Akila," Ibid. CLVI (1904), pp. I35 ff. 
a high position in public service, and he received the title of Vir multarum artium et consumati judicii. He wrote a collection of love songs entitled Plandovańa (Otiosities), several eclogues, Pastirski Razgovori (Pastoral Conversations), one book of sacred poems, Pesni Duhovne (Spiritual Songs) and one epic, Mandalena Pokornica (Magdalene the Penitent).

The lyrics of Bunić are in more perfect form than the poetry of his predecessors of the 16 th century. He was able to combine with spiritual delicacy and fineness of perfection, that humanitas, which is so essential to the poets of the Renaissance. His eclogues are modelled on the "Idyls" of Theocritus, but the names of the personages (Lubdrag, Isubica, Radmilo, Raklica, Zagorko, Zorka, etc.) are Jugoslav. These pastoral songs, for the most part, express the sentiment inspired by the beauty of human relationships and the world at large. They suggest the charm of Dalmatia, the fresh life of the Ragusan spring, the delicate hues of the wild flowers and the quiet beauty of the pastures and orchards of his native district. His Spiritual Poems are mostly reflections on God, man and life. They are pleasing, philosophical, and sublime. Magdalene the Penitent is the same Mary Magdalene who was mentioned by the Evangelists ${ }^{4}$ as the "sinner" out of whom "seven devils were gone forth." As Gundulic divided the Tears of the Prodigal Son into three plača (bewailings), so Bunić divided his poem into three cvilena (wailings). The first one sings of the entrance of Magdalene to the church, where she sees Christ and begins to weep, confessing her sins and anointing his feet. In the second wailing Mary goes to the house of one Simon, where she again finds Jesus, and where she moistens his feet with her tears, and wipes them with her hair, and Jesus says to her: Tebi gresi su oprošteni, jer si mnnogo lubila (Unto thee are thy sins forgiven, for thou hast loved much). In the third canto she sees Christ crucified, assists at the entombment, and witnesses his resurrection. At last she has a vision, and talks with Him. The poem includes some splendid lyric passages full of the purest religious fervor.

${ }^{4}$ The New Testament, Luke, VII, 36-50; VIII, I-3; X, 39; John, XI, 2, 5, 32; XII, 3; XXII, II, I6; Matth., XV, 39; XXVI, 7; Mark, XIV, 3; XVI, I. 


\title{
THIRD PERIOD
}

\author{
THE AGE OF DECLINE
}

\section{CHAPTER VII}

THE ACADEMIES AND SOCIETIES

I

In the I8th century Jugoslav literature began to decline, not only in Ragusa but also in the other provinces. Serbia proper was under the domination of the Turks; Croatia and Slovenia, under Austria, while the Republic of Dubrovnik, after the terrible earthquake of 1667 , was reduced in wealth and population. Besides, Ragusa was suffering from the vexatious attitude of the Venetians and the Turks, who were conspiring together for the destruction of the last Antemurale Christianitatis in the Balkan Peninsula. So long as the Ragusan conmonwealth was independent and vigorous, Slavonic life rested on the identity of the man with the citizen. The city state, as in old Greece and later in Rome, was the highest unit of social organization. ${ }^{1}$ The whole training and character of the man were planned for his membership in the city. The market-place, the assembly, the "academies" were places of frequent meetings, where the sense of citizenship was quickened, and where common standards of opinion or feeling were formed. Poetry, music, sculpture, literature and art, in all their forms, were matters of public interest. The cultural achievements of Dalmatia reached their apex in the 17 th century. No doubt many exquisite works were produced at a later period, but they do not exhibit any creative talent, and more or less conspicuously belong to the decadence

${ }^{1} C f$. Ivan Smirnov, "Gorodskija obščiny Dalmacii v X-XI vĕkě," Zurnal ministerstva narodnago prosvěččenija, čast 214, pp. 289-306, April, 188I. See also his study, "Otnošenija Venecii k gorodskim obščinam Dalmacii s XII do poloviny XIV věka" (I880). 
of Ragusan learning. The only new literary phenomenon of the period was the rise of a school of history, chronology and biography. The eighteenth century bears a peculiar stamp. It is the century of compilations, researches, copying and commenting upon the manuscripts, collecting the materials and preserving them for future generations.

For literary and scientific purposes there were founded at Dubrovnik in the 18 th century several societies or "academies." As indicated above, one of these societies existed even in the I6th century, the Akademija Složnih. Now there were four more societies. One was the Akademija Dangubnih (Academia Otiosorum), founded at the end of the 17 th and continued in the 18 th century. Its president or director was for a certain time Igńat Đorđić, and its founder Đura Matijević (1669-1728), linguist and satirist. ${ }^{2}$ The members of the Academy were: Ivan Aletić Natali (d. I743), lexicographer; Stepo Rusić (d. I77o), author of Petar Aleksiević, an epic glorifying the reforms of Peter the Great and Russia at large; Igńat Gradić (1655-1728), author of the Plam Severski (Northern Glow), also an apotheosis of Russia and the "northern hero," i.e., Peter the Great; Bernardo Zuzorić (I683-1762), a Jesuit orator who left us Besede Duhoone (Spiritual Sermons); Frano Lalić (d. 1722), who wrote Bestužanstvo (Indolence), a philosophical and didactic composition; Vićentije Petrović (I677-I754), a lyrist; ${ }^{3}$ Ivan Bunić, Jr., born in 1662, died in 1712 , who was several times president of the Republic, and from whom remained only a few translations of the Latin poets.

Another society was the Akademija Pokladnih (Academy of the Bacchanals). Its membership is not definitely known. More important than this was the Akademija od Sturaka (Academy of the Crickets), founded in I7I9 in opposition to the Academy of the Otiosi. Its president was Frano Getaldic (fl. I650) and the founders, Antun Gleđević and P. Kontistić. This academy did not have such a reputation as the Academia

2Some of Matijević's poens have the following titles: Women in the Present Times; A Little Poem in Praise of Shrews; A gainst Worldly Love.

3 For his biography and some of his Latin poems, see Đura Kerbler, Rad jug. akad., lib. 186 (I9I I), pp. I85 $f$. 
Otiosorum neither because of its works nor because of its members. At times it was the laughing-stock of the town.-The Akademija Slovenskog Jezika (Accademia della Lingua Slava) was also a literary society, with its seat not in Ragusa but in the eternal city of Rome. Its main goal was the cultivation of the Slavonic languages and literature. It appears that the members of that society were in correspondence with the Academy of the Otiosi.

As said before, the president of the Academy of the Otiosi was Ignat Đorđić (1675-1737): His name however was not known so much in connection with that position as through his poems, his religious compositions and his historical writings. While still a youth he studied rhetoric, poetry and philosophy, perfecting his philologic knowledge of Greek, Latin and French. Entering the great council in his twentieth year, he had the intention of marrying, as he was the last male descendant of his family. Later he changed his mind and went to Rome where he entered the Jesuit order and remained about eight years. Returning home he lived as a man of letters. In I 706 he entered the Benedictine order, changing his first name from Nikola to Ignat. After that time he travelled several times to Italy (Naples, Padua and Venice) for scientific and literary researches. One of his works is in Latin, Vitae et Carmina nonnullorum illustrium civium Ragusinorum, edited by the Serbian Academy of Sciences and Arts (1905). It is one of the best sources for the biographies of the Ragusan authors. Other works are in Serbian, but unfortunately some of them have remained in manuscript form, especially the love songs, written before he entered the order of Jesuits. Like his predecessor Bunić, he wrote Eclogues, but with somewhat better success than the latter. He-left two epic poems, Uzdasi Mandalene Pokornice (Sighs of Magdalene the Penitent) and Pripoves od Krala Selimira (The Story of King Selimir), one parody, Marunko $i$ Pavica, written in the style of Gučetic's "Derviš," and one drama, Judith (not finished). He made the best and most complete translation of the Psalms, Saltir Slovenski (The Slavonic Psalter). He turned into Serbian 
verse the prayers of St. Thomas Aquinas, Razlike Pesni Duhovne (Various Spiritual Songs), Virgil's "Aeneid" (first book), and works of some Italian writers.

Of all these writings the most important is the Sighs of Magdalene the Penitent, composed about 1705 and published in I728. The material which Đorđić took for his Magdalene is a little different from Bunić's. ${ }^{4}$ His poem is based on a legend which took root in the Latin Church during the Middle Ages. According to this tradition, Mary Magdalene belonged to a wealthy family at Magdala and Bethany; she abused all her admirable gifts to tempt others to sin, and after the Ascension she remained at Bethany till the disciples were scattered by persecution which followed the martyrdom of Stephen. Mary, her sister Martha, and her brother Lazarus, with some other companions were placed in a boat by their persecutors and were providentially carried without oars or sails to Marseilles, where by their preaching and miracles they converted the heathen. Lazarus was made bishop, while Mary, remembering her sins, retired to the wilderness and lived a life of extreme asceticism for thirty years. Finally she was carried up to heaven in the arms of ascending angels. ${ }^{5}$ The story is extended and dilated by Đorđic into eight cantos or uzdisana (the sighs) with 68I strophes. The metrical structure of this poem is not always regular, but the diction is vivid and light, with ample antitheses and rhetorical figures. It is not without significance that one of his contemporaries pronounced it the best poem of its time. For more than two centuries no real attempt has been made to supplant it-with few attempts to correct or add to it even a line. ${ }^{6}$

- See supra.

'Vid. "De S. Maria Magdalena apud Massiliam," in the Acta Sanctorum, Julii, V (I868), I $88 s q$.

${ }^{6}$ M. A. Vidović translated this epic into Italian, Sospiri di Maddalena penitente (I 829). Of the Italian authors who cultivated the same theme are Antonio Alemanni (or Alamanno) with his comedy, La rappresentazione della conversione di Santa Maria Maddalena (1521), and Erasmo da Valvasone (1523-I593) with his epic poem, Lagrime di santa Maria Maddalena. Of modern European plays dealing with the same subject the most popular are Paul Heyse's Maria von Magdala (1899) and Maurice Maeterlinck's Marie Magdaleine (1910). 


\section{CHAPTER VIII}

THE MORALISTS AND MINOR AUTHORS

The faint flame of Jugoslav literature flickered out before the I8th century had reached its close. Intellectually, it was certainly not a glorious century in Illyria's (Jugoslavia's) development, and yet there had been some germs of vitality and elements of promise in it. What might have happened had the nation been spared the desolation of the Turkish inroads, it would be difficult to say, but it is certain that the general unrest produced by the wars retarded the growth of literature. The main fact is that the Jugoslav people fell into a slavish imitation of the customs and ideas of foreign countries. The Croatians imitated the Italians, the Slovenians both the Italians and the Germans, and the Serbs, Orthodox in religion, imitated the Russians. That this period of imitation and assimilation lasted so long was due to the untoward political and social conditions. However, some indications of a revival of intellectual life could be found in a period of romanticism, which was soon followed by a rationalistic movement. This however agitated at first the surface of national life, and its real significance was perceived only in the succeeding century. The principal representatives of these movements, who are at the same time the first Jugoslav moralists, are Andra Kačić Miošić and Dositije Obradović.

Andra Kačić Miošić (1702-1760) is the Jugoslav Percy and the first national bard. He was born in Brist, Dalmatia, and as son of a country gentleman, had to go to the monastery of Zaostrog for his first education. Later on he studied philosophy and theology at Buda-Pest. Returning home he became lecturer on the same subjects in the city of Sibenik. Being interested in Jugoslav folklore, as a public-spirited man he travelled in his spare time from town to town and took notes of national traditions. In this way he wrote his Razgovor Ugodni Naroda Slovenskoga (Pleasant Talk of the Slavonic People), a book of 260 poems, or Pesmarica (The Book of 
Songs), as it was popularly called. ${ }^{I}$ These Razgovors are not real folk songs, but only historical narratives, collected and written in the ballad-style of the medieval minstrels and Russian kobzars. In addition to almost every one of his ballads the author gives commentaries on the Slavonic countries, and records in prose by chronological order the heroes they produced. He strengthened the Jugoslav idea of national consciousness, and his work soon became one of the most popular among the masses. ${ }^{2}$ His main characteristics are purity of language and simplicity of style. In 1764 his Pesmarica was translated into Latin, Descriptio Soluta, by Emerico di Budua (Emerik Pavić). Miošić wrote other books (Elementa Peripatetica, pub. 1752, Korablica, pub. I836), but they are of less literary value.

Associated with Miošić as moralist and popular writer was the philosopher Dositije Obradović (I742-18II), the founder of the rationalistic school in Serbian literature. He was born in Čakovo, Banat, the son of a furrier. At first he was apprenticed to a trade, but later proceeded to the monastery of Hopovo, Syrmia. ${ }^{3}$ Here he spent considerable time, and became a monk, changing his original name Dimitrije into Dositije. Showing more aptitude for learning than consecration to the Church, he escaped from the cloister and visited Croatia, Dalmatia, Montenegro, Corfu, Greece, and Asia Minor. He learned Latin, Italian and Greek, and studied the moral and philosophical sciences which flourished at that time among the Greeks. Still wishing to study and acting as a private teacher, he visited Germany, France and England, and made the acquaintance of their languages and literatures. ${ }^{4}$ In I 806 Obradović returned to Belgrade, now the capital of Jugoslavia, where he ended his days as an educator

${ }^{1}$ It was first published in Venice, 1756 , ten years prior to the publication of the famous Percy's Reliques of Ancient English Poetry (1765).

${ }^{2} \mathrm{P}$. Solarić (see infra) called him najreći iliričeski pesmotvorac (the greatest Jugoslav poet), although he never pardoned him for using skjavet or schiavet (i.e., Latin letters in Slavonic words) instead of Cyrillic. Quoted by N. Andrić, Rad jug. akad., lib. 150 (1902), p. I63.

${ }^{3}$ See T. Ostojić, Dositej Obradović u Hopovu (1907).

${ }^{4}$ During his stay in England he extensively read Swift, Pope and Addison (Spectator and Vision of Mirza). In some of his letters he gave good 
and man of letters, much as Emerson, with whom he has some points in common, did at Concord, Mass.

The life of Obradović is an example of a real self-made man, one of those noble spirits who begin with nothing and succeed by their extraordinary perseverance. He takes rank among the foremost Jugoslav writers who mastered the philosophical rationalism of the $\mathbf{I} 8$ th century. He left several works. The first and perhaps the finest one is his autobiography, Život $i$ Priklučenija (Life and Adventures), written in the vernacular as spoken in Serbian towns. It was published in I 783 and is full of didactic eloquence and abiding enthusiasm for letters and sciences. The work abounds in rehement protests against the ignorance and the idleness of the monks, which he had experienced personally, and which destroyed one of the most cherished ideals of his youth. It immediately made a great impression on his contemporaries, and soon was followed by the publication of the Saveti Zdravoga Razuma (Counsels of Pure Reason) and especially by his Fables of Aesop and Other Writers (1788). The Saveti are a collection of essays which rise into the region of moral and religious meditation. The fables (basne), of which some are taken from Phaedrus, Lessing and La Fontaine, are accompanied by long original commentaries or naravoučenija (morals), written in a lively and interesting manner for the practical life of his readers. To him belongs the credit of being the first who introduced fable-writing not only into Serbian but into Slavonic literature in general. ${ }^{5}$ In 1803 he published Ethics or Moral Philosophy, one of the most remarka-

accounts of the literary and social life of England in the eighties of the eighteenth century. He had especially well-founded opinions on English women and girls, characterizing them as extremely beautiful creatures (prekrasna stvorena). He says further: "If I had a thousand eyes, I would not be tired looking at them for a thousand years! The longer you look, the handsomer they appear to you. Do you wish to be safe, go straight on your way, do not glance at them, for if you only raise your eyes towards them and look, you couldn't proceed farther; you will remain there forever. . ." (Život $i$ priklučenija Dimitrija Obradovića, II, I893, p. I06-Srpska kńiževna zadruga, n. 8).

${ }^{6}$ In this way Obradović was the forerunner of the illustrious Russian fabulist, Krylov, whose fables appeared about fifty years later. 
ble of his speculative works. His compositions Pervenac (First Essay) and Mezimac (Last Essay) are of no high merit.

The writings of Obradovic enjoyed an excessive popularity at the time of his death, but since then they have undergone apparent diminution, and will probably continue to decrease in popularity. This eminent philosophical reformer and prosvetitel (enlightener) was a very honest man-no sophist, no rhetorician. In a lucid, intelligible and convineing style, he placed before Jugoslav readers views of an advanced character, with the value of which he was sincerely impressed. However, as to the durability of his books, he is fervid without being exhilarating, heartfelt without being convincing. Skeptical, precise and plain, his books inspire respect, but unfortunately do not attract new generations of admirers. ${ }^{6}$

In the I $7^{\text {th }}$ and 18 th centuries literature was cultivated in the Southern Slav provinces by a great many persons who have no place at all, or but a secondary place, in the history of the development of style. They must not, however, be entirely overlooked, and for practical purposes they may be divided into three classes. Firstly, there were those who continued to imitate their predecessors in poetry. Secondly, there were those who had something to say about scientific

- The complete works of Obradović have been published several times. The first edition is by G. Vozarević, in Io vols., Beograd-Kragujevac, I833I 836 ; second edition, Zemun, I850; third ed. by Narodna Biblioteka Braće Jovanovića, Pančevo, I882-1884; fourth State ed. by J. Skerlić, Beograd, 1911. The selections of his works were published by Srpska kńiževna zalruga of Belgrade as follows: Život i Priklučenija, I-II (1893); Basne, I (1895), II (1896); Domaća Pisma (1899); Izbor iz Poučnih Sastava (1004). There are in Jugoslav and foreign languages many accessible essays bearing on the life and works of Obradović; some of the best of these are: And. Gavrilović, Dositije Obradović, kńiževne rasprave, novi prilozi, misli i beleške, Beograd, 1900; K. Radčenko, Serbski pisatel Dositej Obradović i jego literaturnaja dejatelnost, Kiev, 1897; Ibid. "Einige Bemerkungen über das Leben und die literarische Thätigkeit Dosithej Obradović's," Archiv f. slav. Philol. XXII (1900), pp. 594ff.; M. Sević, Dositheus Obradovic, ein serbischer Aufklärer des XVIII Jahrhunderts, I.eipzig, I899; Ivan Šercer, "O Dositeju Obradoviću," Rad jug. akad., lib. I 34 (I898), I6II89; L. Leger, "La renaissance intelectuelle de la nation serbe: Jean Raïtch et Dosithée Obradovitch," Journal des savants, Sept.-Oct. 19II. 
speculation. Thirdly, there was the mass of miscellaneous writers, historians, autobiographers, chroniclers, translators, and the like, who with infinite patience and self-satisfaction built up the secret history of the age or helped to preserve its documents. Concerning these lesser writers of the republic of letters, it is to be confessed that their writings present no features of great interest, apart from the facts or the ideas with which they deal. Every one of them has a tendency to wordiness; all become tedious at last from their untiring sinuosity. They are didactic and scholastic in their attitude to literature; their ambition makes them of ten cumbrous, and they are delightful only when some gleam of human experience seduces them into forgetfulness. Everything points to the necessity of relieving Jugoslav literature by elements of lucidity, brevity and grace - those qualities, in fact, which one can find only in the authors of the igth century.

The writers who mostly attract our attention after the earthquake in Dalmatia are Petar Kanavelić (I637-I719), Jaketa Palmotić (1623-1680), V. Pucić (d. I666), Vladislav Menčetić (d. I666) and Antun Gleđević (I659-1728). Kanavelić and Palmotić are the poets who sought motifs for their poems in the disaster of 1667 and in the deeds of arms. The latter wrote an epic, Dubrovnik Ponovlen (Ragusa Renewed), in twenty cantos. Gleđevic is the author of several dramas, of which the more important are Zorislava, Ermiona, Olimpia, Belizario, and Damira. ${ }^{7}$ Traces of historic events are also to be found in the poems of Petar Zriński (I62I-I67I) and Frano Krsto Frankopan (d. I67I), two Jugoslav patriots and martyrs, who were decapitated by the Habsburgs in Vienna (I67I). They are followed in epics and historic works by Pavle Vitezović (I652-I7I3), Jeronim Kavańin (c. I640-I7I4), and Matija Relkovic (I732-I798). All these poets were highly ideal in their conceptions and strongly patriotic, with an ardent love of liberty. ${ }^{8}$

7 The complete works of this author are published by the Jugoslav Academy (Stari pisci hrvatski, vol. XV, 1886).

${ }^{8}$ Kavańin's epic Bogatstvo $i$ ubostvo (Riches and Poverty), consisting of 32,658 verses in thirty cantos, was published with introduction by Ivan Kukulević at Zagreb, i86I. 
In prose composition, as in poetry, the national spirit is marked by an abundant output. Among the historians most deserving of notice is Mavro Orbin (d. I6I4), whose Il Regno de gli Slavi is a monumental work. ${ }^{9}$ It is distinguished by clearness of exposition and is the first attempt to deal with the history of the Slavs as a comprehensive whole. ${ }^{10}$ Other historians are Ivan Valvazor (I64I-1693), who dealt with the geography and cultural history of Slovenia, and Juraj Križanić (I6I7-I680?), the father of Panslavism (Sveslavenstvo), whose historical and politico-economic writings, done in Russian, contain much interesting information about the social life of all Slavonic peoples. ${ }^{11}$ George Branković (I645-I7II) wrote a chronicle of over 2,000 pages, which remained in MS. form and was only partially published after his death. Like Križanić he was an ardent partisan of Russia, and as such an object of suspicion to the Austrian Court: which kept him in prison for many years until he died. ${ }^{12}$ With him must be mentioned Jovan Rajić (I726-I80I), who wrote the History of the Serbs, Croats and Bulgars, the first systematic work on the past of the Jugoslavs, and Hristifor Žefarović (d. I753), whose Stemmatography for a long time has been regarded as the best book on Slavonic heraldry. The works of other historians, Vasilije Petrović (I 709-I766), Miho Milišić (I 7I I-I798), Adam Krčelić (I 7I5-1778), and Jovan Muškatirović (1743-1809), are of only local importance.

The men of science who deserve to be remembered are Marin Getaldić (I566-I627), Ruđer Bošković (I7II?-I787), Manojlo Janković (I758-1792), and Atanasije Stojković $\left(1773^{-1832}\right)$. For a time Getaldic held the chair of professor of mathematics in the University of Louvain. His

${ }^{2}$ The Russian translation of this work, Istoriografija počatija imene Slavy, was made by Theofan Prokopovič, and published in Petrograd, 1722.

${ }_{10}$ This work was one of the principal sources from which Gundulic took material for his epic Osman.

11 The Panslavistic teaching and adventures of Križanić are extensively treated by V. O. Kluchevsky in his History of Russia, III, I2, pp. $255 \mathrm{ff}$. (English translation, London, I9I3); see also Iv. Kukulević in his Arkiv za povesnicu jugoslovensku, X (1869), pp. I I-75.

12 Vid. Gavrilo Vitković, "Kritički pogled na prošlost Srba u Ugarskoj," Glasnik srpskog učenog društva XXVIII (1870), pp. I33 ff. 
book Promotus Archimedis was written in Latin and published in Rome, I603. He is said to have applied algebra to geometry before Descartes, and to have been the first to effect equations of the fourth degree. Bošković was a pattern of the blended erudition that distinguishes the eighteenth century scholarship. He is one of the first savants who adopted Newton's gravitation theory. Born at Ragusa, he studied mathematics and physics at the Collegio Romano. In I764 he was called to the chair at the University of Pavia, and in $\mathbf{I} 773$ was appointed Director of Optics to the French Ministry of Marine at Paris. His most important works are Theoria Philosophiae Naturalis ( $75^{8}$ ), expounding the molecular theory of matter as well as his philosophical principles, and Opera Pertinentia ad Opticam et Astronomiam, which appeared in I 785 in five volumes quarto. In addition to these he published Elementa Universae Matheseos (1752), the substance of the course of study prepared for his pupils, and De Solis ac Lunae Defectibus (1760) in 5,000 lines. ${ }^{13}$ Janković and Stojković were contemporaries of Bošković, but the intellectual distance between these men is so great that they seem to belong to different ages. ${ }^{14}$ The superficial essay, Fizičeskoe Sočinenie (Treatise on Physics) of Manojlo Janković cannot be compared in any way with the brilliant treatises of Getaldic or Bošković.

${ }^{13}$ The peculiarity of this last work, which makes it unique in Jugoslav literature, is that it is a reasoned system of philosophy and natural phenomena, written in Latin verse, and in the special strain of De Rerum Natura by Lucretius, the poet and physicist. The poem as a whole shows such unrelieved intensity of thought and feeling coupled at times with sombreness that Delambre, his rival in physics, characterized it as "uninstructive to an astronomer and unintelligible to any one else." Sources for the life of Bošković abound in Italian, French and English archives. On the occasion of his centenary (1887), the Jugoslav Academy devoted three volumes of its main organ (Rad) to the memory of the great scientist, including the biography, bibliography and criticism of his works. (See "Život $\mathrm{i}$ ocena dela Ruđera Josipa Boškovića, uspomeni prve stogodišńice smrti ńegove," Rad jug. akad., vols. 87, 88, 90, Zagreb, 1887-88.)

${ }^{14}$ Manojlo Janković was more noted as a philosopher and man of letters than as a scientist. He was a native of Novi Sad, Banat, and his critics regard him as a rude precursor of Vuk Karaǵić, the reformer of Serbian language. 


\section{III}

Works of a religious tendency were written by the following authors: Matija Divković (d. I63I), Bartolomej Kašic (1575-I650), Tomaž Hren (1560-1630), Atanasije Grgičević (1590-1650), Juraj Habdelić (I609-1678), Matija Kastelec (I623-I688), Pavle Posilović (d. I65I), Vid Andrijašević (d. I688), Antun Kanižlić of Požega (1700-r777), Blaž Kumerdej (I738-I805), Vićentije Rakić (1750-r818), Ivan J. Lučić Pavlović-Makaranin (I758-1818), Emerik Pavić (17161780), Tomaš Mikloušić ( $1767-1855$ ), and Juraj Japel ( $1744^{-}$ 1807). The last is the reputed translator of the whole Bible into the Slovenian vernacular, Svetu Pismu Stariga (in Novega) Testamenta (1784-1802). Before Japel, the Scripture was translated by the famous Slovenian reformers, Primož Trubar (I508-I586), with many Germanisms, and Juraj Dalmatin (I550-1589), who translated it into pravi slovenski jezik (the true Slovenian language). But their translations are colored by Luther's teaching, while the popular version of Japel is made for the Catholics. The works of these first theologians have many times been the cause of vehement dogmatic controversies, which have never ceased in Jugoslavia among the ecclesiastical writers.

In the domain of linguistic production, there were many works written during this period, but they show little originality and much foreign influence. Through the whole 18 th century Serbia was indirectly under the sway of Russia, or rather of the Russian Orthodox Church. ${ }^{15}$ In the meantime Slovenia and Croatia, owing to their dependence on Austria and Hungary, were moulded by the Roman Catholic Church. Of the Jugoslav authors who followed the Russian models it is worth while to mention Zaharija Orfelin (1726-1785), Grigorije Trlajić (I766-I8II), and Pavle Solarić (I 78I-I82I). Orfelin

${ }^{15}$ Hence the expression Russo-Slavonic language, which was not readily understood by the Serbian reading public, and which through the influence of the living dialect began later to approach nearer to Serbian than to Russian, and was called Slaveno-Serbski (Slavo-Serbian). In the Igth century this artificial literary jargon was superseded by the modern Serbian language due to the efforts and reforms of Vuk Karaǵić. 
was the editor of the first Jugoslav review, Slaveno-Serbski Magazin (1768). Trlajić, the "Slavonic Xenophon" as D. Obradović called him, is the translator of Marcus Aurelius, Fénelon ("Télémaque"), and some German authors. Solarić was a gifted pupil of Obradović. He left several translations from German, French, Italian and English, as well as some original linguistic and geographical essays. ${ }^{16}$

The works of Croatian and Slovenian authors, like the Serbian, hardly contributed anything towards progress in linguistic science and literature. Among them are Ivan Žiga Popović (I705-I774), and Marko Pohlin (I735-1801), who wrote grammars, dictionaries and other books for the Slovene population in Carniola and Carinthia. The Franciscan monk, Lovro Luubuški (c. I7I3), is the author of Gramatica Latino-Illyrica (1742), a discourse of minor philological value. Of especial interest is Tito Brezovački ( $1754-1805$ ), comedist and poet, a man endued with an intellect pellucid and brilliant. He wrote in Latin as well as in Croatian (erroneously called "Slavonian" from the province of Slavonia). Many satirical poems were published in the periodicals of that time. In both his ribald songs and comedies he applied his rare powers of observation to studying the peculiarities of every class of people, their humors, prejudices and passions. To all these he knew how to appeal with exquisite propriety. His play Matijaš Grabancijaš $Đ a k$ (Matijaš the Magic Student) was the first Croatian book written in štokavski dialect-the dialect which later was accepted as the literary language in all Jugoslavia.

${ }^{16}$ How much Solarić was influenced by English literature is difficult to say. His translation Mudrolubac Indijski (The Indian Philosopher) is from a French book, "L'art de vivre heureux dans la société," and this is only an extract from the famous Chesterfield's "Letters." See N. Andrić, Rad jug. akad, lib. I50 (1902), p. I43. 


\section{CHAPTER IX}

\section{EPILOGUE}

The literature of the Southern Slavs in the period of decline (18th century) does not appear much superior in its genre to the church literature of the first period. We have seen that in early stages of Serbian society the art of writing was monopolized by monks and priests. These ecclesiastics were the first who attained a distinct literary utterance, in their translations of the Scriptures and their chronicles of national religious development. Their sacred books, canons, biographies, apocrypha and epic rhapsodies supplied a standard of literary taste. But these literary monuments, being only pale semblances of the extensive Grecian literature, remained sterile and without any wider influence. They were destitute of ideas and sentiment, and served as the pleasure of a small caste of noblemen. They did not have the slightest influence either on the people or on the Renaissance writers of the Adriatic coast. There are several political and religious causes for this exclusiveness, but one of the most evident is the dualism of language and orthography. The medieval Serbian literature was written in the Old Slavonic dialect which was not easily intelligible to the masses of the people, as Latin (sermo urbanus) became a sealed book to the Italian and French people (who spoke sermo rusticus). On the other hand, the Renaissance literature of Dubrovnik was written with the Latin alphabet and this was not accessible to the eastern Jugoslav authors, who used exclusively the Cyrillic script, not only in the I8th but even in the I9th century. These centrifugal forces acted disastrously on Jugoslav literature at large and created a tribal particularism and confusion of which traces are still extant.

The Slavonic revival of the Ragusan period did not produce Petrarchs, Calderons, Ronsards, and Chaucers. The chief representatives of the age, Šiško Menčetić, Marin Držić, Gundulić and Palmotić, were great on the human but weak on the artistic side. They have in full measure the energy, the sincerity and the strong feeling which are necessary 
for the creation of a literary work, but they lack the sense of form which is required to perfect the artistic conception. It is not too much to say that no work of magnitude by any writer of the Jugoslav Renaissance is constructed on a preconceived plan. Most of them write as their mood prompts them; they give free rein to their emotion and thus become its slaves instead of its masters. They compose poems and dramas too fluently and too easily, without having sufficiently refined their ideas in the crucible of imagination, without having transmuted the rough ore into the gold of poetry. They go on writing after their inspiration is exhausted, and as a rule inspiration comes to them only in short passages. It is needless to multiply instances. The artistic execution of these men of letters surpasses their artistic conception, but it is the execution of gifted amateurs rather than of trained artists. For all their admiration for Greek poetry, our classicists failed to learn from their masters the lesson of self-restraint, simplicity, and moderation, of patient and accurate workmanship.

This failure to realize the classical ideal of literary art was due to the lack of the critical spirit. The Ragusan authors formed practically a literary school among the members of which existed great personal friendship. And we know from experience that friendship and solidarity are a hindrance to originality; mutual admiration is fatal to self-criticism. To create this spirit of rational criticism was the work of Dositije Obradović. But he came too late; his spiritual and intellectual force was turned in another direction. The work of Obradović was perfected by Vuk Karaǵić, Đura Daničić, and Isudevit Gaj. These men brought into connection the two branches of the Jugoslav people by employing to a considerable extent both the Cyrillic and Latin alphabets. They also used themes drawn from the culture of both divisions of the people. In this way Jugoslav literature became national in spirit, as the works of these reformers and their followers were accepted as classical. But to trace the history of that new development of the nineteenth century, to investigate the various causes which made Jugoslav literature national instead of provincial, social instead of individualistic, rational instead of imaginative, lies beyond the scope of the present treatise. 



\title{
BIBLIOGRAPHY
}

\author{
LITERARY HISTORIES, MONOGRAPHS AND ARTICLES
}

Andrić, Nikola. Prevodna beletristrika u Srba od godine 1777-1847. Zagreb, 1892.

Appendini, F. M. Noticie istorico-critiche sulle antichità storia e litteratura de' Ragusei. Ragusa, I (I802); II (I803).

Badalić, Hugo. Hrvatska antologija. Umetno pesništvo starijega i novijega doba. Izdańe Matice hrvatske. Zagreb, I 892.

Bogdanović, David. Pregled kńiževnosti hrvatske $i$ srpske. Kńiga prva. Zagreb, 1914. (2 ed. 1916.)

Bošković, Jovan. "Pisma o kńiževnosti srpskoj i hrvatskoj." Letopis matice srpske, lib. I70-I 7 I (I 892), lib. I82 (I 895).

Broz, Ivan. Crtice is hrvatske kniževnosti. Naklada Matice hrvatske. Zagreb, I (I 886); II (I 888).

Burr, Malcolm. "The mediaeval literature of the Serbs." (Oxford and Camb. Rev., XIII, I9II, pp. II 5-131.)

Cerva, Seraphinus (I686-1759). Bibliotheca Ragusina, in qua ragusini scriptores, eorum gesta et scripta recensentur. (MS. in the Ragusan Dominican library, containing about 500 biographies in 4 vols. Written in Ragusa, I740-42.)

Dulcius (Dolci), Sebastian (1689-1777). Fasti litterario-ragusini, sive virorum litteratorum, qui usque ad annum 1766 in ragusina claruerunt ditione, pp. I-66. Venetiis, I767.

Fancev, Fr. "Einige Bemerkungen zur Geschichte des Schrifttums in Kroatien." Archiv f. sl. Phil. XXXV (19I4), 379-4I3.

Galleria di ragusei illustri. Ragusa, $\mathrm{I} 84 \mathrm{I}$ in $4^{\circ}$. (Written and edited by several authors.)

Gavrilović, A. Istorija srpske $i$ hrvatske kńiževnosti. 3 vols. Beograd, I9I0-19I2.

Georgius, Ignatius. Vita et carmina nonnullorum illustrium civium ragusinorum. (Written about I 7 I5 and published by the Serbian Academy of Sciences: Zbornik za istoriju, jezik i kńiževnost srpskoga naroda, drugo odeleńe, II kńiga. Beograd, 1905.)

Glaser, Karol. Zgodovina slovenskega slovstva. Založila Slovenska matica. 4 vols. Isublana, I 894-98.

Gliubić, S. Dizionario biografico degli uomini illustri della Dalmazia. Vienna e Zara, 1856.

Grčić, Jovan. Istorija srpske knížernosti. Novi Sad, I903. (2 ed. I906.)

Hauser, Otto. "Die südslavischen Literaturen," in his work Weltgeschichte der Literatur, II, pp. 341-364. Leipzig und Wien, I9Io. 
Jagić, Vatroslav. Historija kúnževnosti naroda hrvatskoga i srpskoga, kn. I, staro doba. Zagreb, I867. (Russian version, by M. Petrovskij? "Istorija serbsko-horvatskoj literatury." Kazan, I87 I.) ha, 1865 .

Jensen, A. Ragusa, en sydslavisk litteraturstudie. Göteborg, I 893.

- - Slavisk kultur och litteratur under nittonde århundradet. Stockholm, I920.

"Jihoslované" (literatura). An article written by M. Murko, J. Polivka, and Đ). Surmin in Slotnik nančný (Ott ův), XIII (1898), pp. 403-503.

Karásek, Josef. Slavische Literaturgeschichte. Sammlung Göschen (277278), 2 vols. Leipzig, 1906.

Kleinmayer, Julij. Zgodovina slovenskega slovstva. Celovec, I 887.

- Priponoček zgodovini slovenskega slovstva, 1550-1880, pp. I-30. Koper, 1879. (An alphabetic onomasticon of the Slovenian literature.) Klun, Vinko F. "Slovency," očerk istorii ih slovesnosti. Russkaja beséda. Moskva, 1859, I, pp. 87-I20; II, pp. 95-I26.

Krek, Gregor. Einleitung in die slavische Literaturgeschichte. Graz, I ed. I 874,2 ed. I 887.

Ǩrek, Ivan. Les Slovènes, avec deux cartes, pp. I-85. Paris, I9I7.

Kř̌ižek, Václav. "Přehled veškeré literatury jihoslovanské," C̆asopis musea království českého. Praha, lib. XXXIII, v. I-4 (I859); XXXIV, v. I-3 (i 860).

Kukulević, Ivan. Slornik umetnika jugoslovenskih. Sa slikama, 4 vols. Zagreb, I 858-I860.

-... - Kńiževnici u Hrvata s ove strane Velebita, živivši u prvoj polovini XVII veka. Zagrel, I 869. (Reprinted from Arkiv za pov. jug. IX-X, I 868-i 869.)

Leban (Gradimir), Janko. Slonstiena zgodovina v slovenski judski šoli, pp. 1-50. 1,ublana, I 885 .

L.epava, J. Lekcije iz istorije srpske kńržernosti. Cetińe, I896.

Lubić, Sima. Ogledalo kúiževne poresti jugoslosenske. Reka, I (I865), II (I 869).

Macun, Ivan. Knh ževna zgodovina slovenskega Štajerja. Gradac, I88I.

- Kratuk pregled slovenske líterature, pp. I-I02. Zagreb, I863.

Medini, M. Povest hrvatske kni ₹evnosti u Dalmaciji i Dubrovniku, sveska I. Zagreb, 1902.

Mijatović, Čed. "Serbian Literature" in his book Serba of the Serbians, new ed. ch. IX, pp. I5I-I70. London, I9II.

Mitrović, B. Studi sulla litteratura serbo-croata, pp. I-II8. Firenze, Iyoz. Morfill, WV. R. "The Literature of the Serbians and Croats," Westminster Revier', CIX (1878), pp. 303-327.

- - Slavonic Literature. London, I883. (In the series: The Dawn of European Literature.)

Murko, Matthias. "Geschichte der ältern südslavischen Literaturen." (In Die Literaturen des Ostens, Bd. 5, Abt. 2.) Leipzig, I908. 
"Die südslavischen Literaturen." (In Die Kultur der Gegenwart, von P. Hinneberg, I, 9, pp. I94-245, Berlin u. Leipzig, I908.)

Novaković, S. Istorija srpske kńiževnosti. Beograd, I867, 2 ed. I871. (Russian version, I877.)

Beograd, I 867. (With Old Slavonic specimens.)

Ostojić, T. Srpska knízevnost, od velike seobe do Dositeja Obrarlovića. Sr. Karlovći, I905.

Pechan, Antun. Povest knižesnosti hrvatske za učitleske pripravnike, pp. I-96. Zagreb, I 878 ( 2 ed. I 883, 3 ed. I 896).

Popović, Pavle. Jugoslovenska kníisevnost. Cambridge (England), I918, 2 ed. Belgrade, 1920.

.Literature." (In A. Stead, Serbia by the Serbians, ch. XXI, pp. 320-336, London, 1909.)

- Pregled srpske kúi Łevnosti. (Stara kńiževnost; narodna kńiževnost; dubrovačka kńiževnost.) Beograd, I erl. I909, 2 ed. 1913. (Russian version, I913.)

Prijatel, Ivan. Istorija najnovije slovenačke kńiževnosti. Letopis matice srpske, lib. 243 (1907).

Pypin, A. N., i W. D. Spasowicz. Istorija slavjanskih literatur. (Petrograd, I 865 , and ed. 1879-80, French trans. by E. Denis, Paris, I88I; German trans. by T. Pech, Leipzig, I $880-83$.)

Ristić, Jovan. Die neuere Literatur der Serben. Berlin, I852. pp. I-47.

Simić, Ż. P. Lekcije iz istorije srpske kńǐrernosti. Beograd, I8go. (2 ed. I897.)

Simonić, Fr. "Die slovenische Literatur." In the collection Die Slovenen, von Josef Šimun, pp. 123-172. Wien, I 881 .

Skerlić, Jovan. Istorija nove srpske kńiževnosti. Beograd, I9ı2. (Larger edition, I9 I4.)

——. Srpska kniževnost — XVIII veku. Beograd, 1909.

Stanojević, Stanoje. Histoire nationale succincte des Serbes, des Croates et des Slovènes. Paris, I9I8.

Stepovič, A. Očerki istorii serbohorvatskoj literatury. Kiev, I 899.

Subotić, J. Einige Grundzüge aus der Geschichte der serbischen Literatur, pp. I-56. Wien, I 850 .

Šafařík, I'. J. Geschichte der slavischen Sprache und Literatur nach allen Mundarten. Ofen, I826. (2 ed. Prague, 1869.)

- Geschichte der südslavischen Literatur. Herausgegeben von Jos. Jireček. Prag, I864-I865. Bd. I. Slovenisches und glagolitisches Schriftthum (I864); II. Illirisches u. kroatisches Schtm (I865); III. Das serbische Schtm (I865).

Surmin, Đura. Povest kńiževnosti hrvatske $i$ srpske. Zagreb, I898. (With illus., facsim. and ports.)

Vulović, Svetislav. Nauka o kniž̌zenosti i izuča vańe slovenskih kńiževnosti, pp. I-I9. Beograd, I882. 



\section{INDEX}

\section{A}

Abgar's Epistles, 24

Abraham, 23, 4 I

Academies (societies)

Dangubnih, $5^{8}$

Jugoslav, 53, 55, 65, 67

Pokladnih, 58

Serbian, 48, 53, 59, 73

Slovenskog Jezika, 59

Složnih, 49, $5^{8}$

Achilles (drama), 55

Acta Sanctorum, 60

Acts of the Apostles, 24

Adam, v. Narratives of

Addison ("Spectator"), 62

Adriatic, 9, 29, 33, 36, 44, 70

"Aeneid," 54f., 60

Albania, 30

Albanians, 4

Alćina (of Palmotić), 54

Aleksandrov, A., 20

Alemani(Alamanno), A., 60

Aletić, Ivan Natali, 58

Alexander the Great, 18,52

Alexandria, 19, 48

Allegories, 19, 42, 53

Alphonse V (king), 38

America, 3 I

American Philos. Soc., 8

"Aminta" (of Tasso), 46

Anacreon, 49

Ancona (city), $3 \mathbf{I}$

"Andria" (of Terence), 47

Andrić, Nikola, 8, 62, 69, 73

Andrijašević, Vid, 68

Andronicus II (emperor), 31

Angles, 3

A pocalypse of Baruch, 23

Apocrypha, 22ff., 70

A postolus of Sišatovac, 14

Appendini, F. M., 48, 53, 73
Archiv (f. slav. Philologie), 8, 20, 23 , $28,37,39,44,49,53,55,64,73$

Aretino, Pietro, 33

"Argonautica" (of Flaccus), 55

Ariadna (of Gučetić), 49

Ariadna (of Gundulić), 50

Arkiv (za pov. jug.), I 4, I 8, 26, 66

Arkulin (of Držić), 47

Ariosto, 5I, 54

Aristotle ("Hist. Animal."), 19

Armida (of Gundulić), 50

Armida (of Palmotić), 54

Armenian sect, 21

Arts, 15, 29, 35, 56f.

Aryan languages, 7, 9

Asia Minor, 2 1, 62

"Aspasia of Ragusa," 49

Assen II (emperor), 3 I

Alalanta (of Palmotić), 54

Atamante (pastoral), 49

Athos (peninsula), 25

"Aulularia" (of Plautus), 47

Aurelius, Marcus, 69

Austria,.3o, 57, 66, 68

Avarus, v. Skup

Avril, Adolphe d', I2

\section{B}

Babuni, v. Bogomils

Badalić, Hugo, 73

Baldwin I (emperor), 3 I

Balkan mines, 32

Balkan Peninsula, +, 1 I, 33, 57

Balkan scenery, 5I

Balkan Slavs, 8

Ballads, v. Folk songs

Ban, Matija, 53

Banat, 62, 67

Bańska (monastery), 26

Baraković, Juraj, 48

Barbary, 3 I 
Bartholomew, v. Questions of

Baruch, v. A pocalypse of

Bashful Lover, v. Luıbavnik

Bašćanska Ploča, I3

Bavaria, I3

Belcari, M. ("St. Panuzio"), 48

Belgrade (capital), $v$. Jugoslavia

Belizario (drama), 65

Besede Duhovne (sermons), 58

Bestiaries and lapidaries, 19

Bestužanstvo (Indolence), $5^{8}$

Bible, I If., 23, 56, 68, 70

Bible-dramas, $4 \mathbf{I}, 47 f$.

Bilbasov, V. A., I2, I3

Biographies, I2, 26, 37, 59, 63, 67

Bisernica (play), 54

Bobalević, Savo, 48

Boccaccio, 36

Bogatstvo i Uboštvo (epic), 65

Bogdanović, David, 73

Bogomils, $20 f f$.

Bogosluzebnye Kanony, 16

Boka Kotorska, 30

Bosnia, I3, I8, 2I, 3I, 33, 52, 54

Bosporus, 31

Bošković, Jovan, 73

Bošković, Ruđer, 66ff.

Book of Alexander, $\mathrm{I} 8$

Book of Enoch, 23

Book of Jesus (of Držić), 47

Book of Songs, v. Pesmarica

Books of magic, 22

Brandt, Roman, $53 f$.

Branković, G. (author), 66

Branković, G. (despot), 32, 52

Brist (village), 6I

British peoples, 3

Brizinski Spominki, 13

Broz, Ivan, 73

Brskovo (mint), 33, 34

Brugmann, Karl, 8

Bryce, James, 16

Buda-Pest, $6 \mathbf{I}$

Buddhism, 2 I

Budmani, Petar, 47

Bugarštice, v. Ballads
Bulgaria, 10, 12, 20, 26, 31

Bulgarian history, 2I, 66

Bulgarian invasions, $3 \mathrm{I}$

Bulgarian origin, 22

Bulgarian translations, 18

Bulgarian veracity, 2 I

Bulgarian versions, 26

Bulgarians, 2, 8f., 66

Bulgaro-Slavonic, 9

Bulgars (short), v. Bulgarians

Bunić (Bona), Ivan, 50, $55 f f$., 60

Bunić (Bona), Ivan, Jr., 58

Bunić (Bona), Miho, 49

Burešić, Marin, 49

Burr, Malcolm, 73

Bury, J. B., $2 \mathrm{r}$

Byzance, 22, $35 f$.

Byzantine Empire, 3I

Byzantine influence, 4,35

Byzantine literature, 22

Byzantine States, 34

Byzantine style, 16

C

Calderon (author), 70

Calisthenes (Pseudo-), 18

Camblak, Gregory, 26

"Canzoniere," v. "Slavonic Can."

Captat (Epidaurum), 30, 54

Captislava (play), 54

Carinthia, 69

Carniola, 69

Carostavnik (chronicle), 26

Carpathians, 4

Catholic Church, 9, II, 68

Catonis Distihia Moralis, 48

Catullus, 46

Cellini, Benvenuto, 43

Cerva, Elias L., v. Crević, Ilija,

Cerva, Seraphinus, v. Crević, Saro

Chalcondylas, Demetrius, 36

Charles, R. H., 23

Chaucer, 20, 70

Chesterfield ("Letters"), 69

Chilandar (monastery), I I , $25 f$.

Christ, I9, 23ff., 4I, 47, 56 
Christiada (epic), 55

Christian canons, 22

Christian Church, I5

Christian poets, $\mathrm{I} 7$

Christian superstitions, 24

Christian traditions, 55

Christian Trinity, 2 I

"Christian Pindar," I7

Christianity, 4, I2, 2 I, 57

Chronicles, I4, I8, 26, 33, 66, 70

Church books, $8 f$., I 7

Church Slavonic, v. Old Slavonic

Cicero, 36

Civilization, $4,5,28,30,35,38$

Clarence (duchy), 3 I

Classical ideals, 70

Classical models, 5

Classical writers, $37,5^{\circ}$

Classicism, 5of.

Codex Marianus, $\mathrm{I} 3$

Codex Suprasliensis, I4

Codices, $13 f$., 16,27

Columbia University, 20

Comedies, $43 f f$., 47, 5o, 69

Commerce, 29ff., 35, 38

Concord (Mass.), 63

Conqquest of Illyria, 4

Conquest of Serb State, 5

Constantine, v. St. Cyril

Constantinople, I6f., 31, 34, 36

Corfu, 62

Creizenach, W., 36

Crević, Ilija (poet), 37

Crević, Saro (critic), 43, 73

Critoboulos, v. Kritoboulos

Croat (short), v. Croatian

Croatia, 35, 46

Bans of, 52, 54

Byzantine influence, 35

Latin influence in, 29

Literature in, 5

Part of Jugoslavia, 3

Under Austria, 57

Visited by Dositije, 62

Zagreb, capital of, 46

Croatian authors, 69
Croatian dialects, 39

Croatian elegies, 4 I

Croatian first book, 69

Croatian first epic, 48

Croatian language, 3, Io, +1

Croatian literature, $4^{8}$

Croatian monuments, 13

Croatian songs, $4 \mathrm{I}$

Croatian text books, 9

Croatian wars, 39

Croatians, 4, 9f., 29, 61, 66

Croato-Glagolitic, 9

Culture, 25ff., 36, 57, 7 I

Customs, 3, 29, 35, 38, 44, 6I

Cyril, v. St. Cyril

Cyrillic, 8, Io, 7of.

\section{$\check{\mathrm{C}}$}

Čakovo (village), 62

Ćasopis (musea českého), 24, 74

Čech Bible, v. Bible

Cechoslovaks, 2

Črnčić, Ivan, It

Čubranović, Andra, +3ff., 52

\section{D}

Dalida (play), 49

Dalmatia, $9 f$., I2, I $8,29 f f ., 35,36$, $42,5 \mathrm{I}, 56 f ., 65$

Dalmatin, Juraj, 68

Damira (drama), 65

Danica (play), $5+$

Daničić, Đura, 8, I4, I7, 26f., 7 I

Danilo (archbishop), 26

Dante, 20, 33, 42

Dares the Phrygian, 18

Descartes, 67

Dečani (monastery), II , 26

Dečanski, v. Life of

Delambre, 67

Derviš (parody), 48, 59

Descriptio Soluta, see Pesmarica

De Solis (of Bošković), 67

Děva Dnes (hymn), 17

Dialects, 3, 5, 7f., 29, 54, 69

Dianna (of Gundulić), $5^{\circ}$ 
Diction, 53,60

Dictes of Crete, 18

Dimitrijević, M., 35

Dimitrović, Nikola, 48

Diocleus, v. Duklanin

"Divine Comedy," 42

Divković, Matija, 68

Dobrovský, Josef, 12

Documents, $v$. Monuments

Dolci, v. Dulcius

Domaća Pisma (of Dositije), 64

Domentijan, 26ff.

Dragutin (king), 26

Dramas, 36, 4I, 43ff., 54ff., 65

Držić (Derza), Đore, $38 f f$.

Držić, Marin, $47 f f, 7^{\circ}$

Dubravka (pastoral), 50

Dubrovnik Ponovlen (epic), 65

Dubrovnik (Ragusa), 13, 70

Academies of, $58 \mathrm{ff}$.

After the earthquake, 57

Architecture of, 35

Celebrities of, 37

City state of, 57

Decline of, $57 f f$.

Fall $(P a d)$ of, 30

Foundation of, 30,54

Golden age of, 50

Italy and, $3 \mathrm{I}$

Latin civilization in, 35

(Literary) school of, 38, 7I

Lyrics and dramas in, 43

Part of Jugoslavia, $3^{\circ}$

Patrons of, $5^{2}$

Relations with America, 3 I

Relations with Venice, 30, 57

Satire fostered in, 49

Serbia and, $3 \mathrm{I}$

Visited by Dušan, 32

Dukjanin, Pop, I4

Dulcius (Dolci), Sebastian, 73

Dümmler, E., I2

Dušan (emperor), 27, 32

Dutch influence, Io
Đ

Đorđić, Igńat, 39, 58, 59ff.

Đorđić (Giorgi), Stepan, 48

Đuho Krpeta (play), 47

Đurđevi Stubovi (monastery), 26

\section{E}

Eastern Church, I 5, 2 I

Eastern Europe, 35

Eastern Roman Empire, 3 I

Eastern Slavs, 9, 28

Eclogues, 45, 56, 59

Edessa, 24

Education, 25, 50, 55, 6I

Egypt, 31

Electra, 46

Elegies, 4I, 45, 50

Elementa Peripatetica, 62

Elementa Universae, 67

Elena Ugrabjena, 55

Emerson, 63

Emotions, I 5, 40, 53, $7 \mathrm{I}$

England, 3, 22, $62 f$.

English archives, 67

English girls, 63

English Historical Review, 16

English literature, 45, 55, 69

English poetry, 62

English tongue, 3

English translations, 23, 66

English women, 63

Enoch, v. Book of

Epics, 43, 5off., 58ff., 65

Epidaurum, v. Captat

Epigrams, v. Pričice

Epirus, 3 I

Epistles, v. Poslanice

Ermiona (drama), 65

Essays, 64, 67, 69

Ethics (of Obradović), 63

Ethiopia, 22

Euripides ("Phoenisoe"), 49

Europe, 2, I8f., 35, 37

European nations, I, 3

European plays, 60

Evangelium Zographensis, I3 
F

Fables, 19, 63

Fancev, Frano, 73

Faithful Shepherd, ''. Ferni Pastir

Fénelon ("Télémaque"), $(x)$

Fishing, v. Ribańe

Filida (pastoral), 48

Fiume, $v$. Reka

Fisičeskoe Sočinenie, 67

Fiziolog, igff.

Flacus ("Argonautica"), 55

Fletcher, Jefferson B., 35

Flora (pastoral), 48

Florence, 30

Fojnica (mine), 33

Folklore, 5, 6I

Folk songs, 48, 62

France, 22, 62

Franko, Ivan, 25

Frankopan, Frano Krsto, 65

Frankopans, 27

French archives, 67

French book, 69

French (language), 59

French (literature), 45

French people, 70

French translation, 27

\section{G}

Gaj, Ludevit, 7 I

Gaj, Velimir, 48

Galicia, 4

Galileo, 44

Galleria di Ragusei illustri, 73

Gaster, M., I I

Gavrilović, Andra, 26, 64, 73

Gazarević, Marin, 48

Geitler, L., IO, I3

Genealogy, v. Rodoslov

Geography, I, I I, 5I, 66, 69

Georgius, Ignatius, $v$. Đorđić

German authors, 69

German clergy, 9

German literature, 55

German miners, 33

German savants, 8
Germanism, 68

Germano-Balto-Slavonic, 7

Germans, 2I, 6 I

Germany, 22, 62

Getaldić, Frano, $5^{8}$

Getaldić (Ghetaldus), Marin, 66f.

Gibbon, E., 2 I

Ginzel, J. A., I2

Giusti, Vincenzo, 49

Glagolita Clozianus, I3

Glagolitic (script), $8 f$.

Glagolitic literature, 29

Glas (srpske akadeniije), 48, 53

Glaser, Karol, 73

Glasnik (srpskog učenog društva), I $7 f ., 24 f f ., 3$ I, 34, 66

Gleđević, Antun, 58, 65

Gliubić, Sima, v. Lुubić

Godišnica (Nikole Čupića), 25

Golden age, I8, 50

Gospel of Miroslav, 13

Gospel of Nicodemus, 24

Gospel of Nikola, I4

Gospel of Rheims, I3

Gospel of St. Thomas, 23

Gothic, 7, 9, 35

Gradić, Ignaat, $5^{8}$

Grada (za pov. kńiž. hrvat.), 54

Gramatica Latino-Illyrica, 69

Grčić, Jovan, 73

Greece, 4, 57, 62

Greek books, 32

Greek classics, 46

Greek (hymns), I 7

Greek literature, I I

Greek mythology, 55

Greek originals, 20

Greek poetry, 7 I

Greek poets, $4^{6}$

Greek script, 8

Greek sources, I 8

Greeks, 4, 22, 36, 62

Gresset, J., 45

Guarini, Giambatista, 36

Gučetić (Gozze), Savko, 49

Gučetić (Gozze), Stepan, 48 
Gundulić (Gondola), Ivan, 56, 66 Dubravka (pastoral), 50

Osman (epic), 5 I

Summary of, 53

Gypsy Woman, v. Jedupku

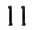

Habdelić, Juraj, 68

Habsburgs, 65

Hauser, Otto, 73

Hecuba (of Držić), 47

Hektorović, Petar, 48

Helena (queen), 26

Henry (enperor), 3 I

Heraldry, 66

Hercegovina (Hum), 21

Hermit, v. Remeta

Heyd, W., 3 I

Heyse ("Maria von Magdala"), 60

Hilferding, A., I2

History, If., 29, 37, 58, 65ff.

Historians, $8,13,43,66$

Holbrook, R. T., 20

Homer, $5 \mathrm{I}$

Hopovo (monastery), 62

Horace, 5 I

Hrabr (mnih, monk), 7

Hren, Tomaž, 68

Hum, v. Hercegovina

Humanism, 32, 37, 56

Hungarian prince, 54

Hungary (Ugarska), 3I, 66

Hvar (island), 45

Hymns, $15 f$.

Hypsipile (tragi-comedy), 55

I

Ichnilat, see Stephanit

Idyls, 45,56

Illyria, 4, 32

Illyrian Kingdom, 30

Illyrian tribes, 4

lllyrians (Albanians), +

lllyrici carminis rex, $5^{\circ}$

Initations, II , 33, 44, 47, 51, 54

Indian fables, 19
Indian Philosopher, v. Mudrolubac

Indies, 32

Indo-European, 7

Indolence, $v$. Bestušanstvo

Isaiah's Vision, 23

Islam, 21

Italian archives, 67

Italian authors, 60

Italian carnival, 44

Italian civilisation, 5

Italian legends, 12

Italian literature, 45

Italian nationalism, 37

Italian people, 70

Italian playwrights, 49

Italian sources, 54

Italian States, 34

Italian style, 5I

Italian translations, 60

Italians, 6I

Italy, 5, 31, 35ff., 59

Izbor iz Poučnin Sastava, 64

Jackson, T. G., 35

Jagić, Vatroslav, 8, 10, 13, 18, 23, $25,27,3^{2}, 38 f ., 47,74$

Janković, Manojlo, $66 f$.

Japel, Juraj, 68

Jaroslav, v. Pravda of

Jedinorodni Sine (hymn), I6

Jedupka (of Čubranović), $43 f$.

Jensen, Alfred, 53, 74

Jeremiah (Bulgarian priest), 23

Jeremiah, v. Paralipomena of

Jerusalem, 23

Jesuits, 59

Jireček, Constantin (Konstantin), 8 , 2I, 28, 33f., 37, 39

Jireček, Josef K., 25, 75

Jokasta (drama), 49

Journal des savants, 64

Judith (of Đorđić), 59

Judith (of Marulić), 48

Jugoslav Academy, v. Academies

Jugoslav apocrypha, 24 
Jugoslav authors, $4,68,70$

Jugoslav culture, 25

Jugoslav folklore, 6I

Jugoslav greatest poet, 62

Jugoslav history, 29, 66

Jugoslav idea, 62

Jugoslav tribal institutions, 4

Jugoslav language, 39, 53

Jugoslav literature, $4,24,5^{1,}, 7$ I

Classicists in, $37 f f$.

Decline of, 57ff.

Division into periods, 5

Dualism of orthography, 70

First printed book, 48

First review in, 69

Masterpieces in, 48, 5 I

New movement, $29 f f$.

Rationalism in, 61, 63

Remote period of, 22

"Jugoslav Laocoon," 52

Jugoslav literary history, 5

Jugoslav littoral, 50

Jugoslav martyrs, 65

Jugoslav moralists, 6If.

Jugoslav muses, 44

Jugoslav names, 56

Jugoslav origin, 22

Jugoslav patriots, 65

Jugoslav people, 3, 6r, 7 I

Jugoslav Percy, 6I

Jugoslav provinces, 3, 2 I

Jugoslav Renaissance, $7 \mathrm{I}$

Jugoslavia, 3, 61, 68

Ancient laws of, $27 \mathrm{f}$.

Belgrade, capital of, 62

Literary language of, 69

Jugoslavs, 2ff., I 8, 26, 28f.

Justinian (emperor), I6

\section{K}

Kačić Miošić, Andra, 4, $61 f$.

Kanavelić (Canavelli), Petar, 65

Kanižlić, Antun, 4, 68

Kanonik, 16

Kanony, see Bogoslužebnye

Karagić, Vuk S., 8, 10, 67, 7I
Karásek, Josef, 74

Karnarutić, Brne, 48

Kastelec, Matija, 68

Kasumović, Ivan, 37, 55

Kašić, Bartolomej, 68

Kavańin (Cavagnini), Jer. 4, 65

Kaznačić, Ivan A., 48

Kerbler, Đura, 58

Kirill i Methodij, $12 f$.

Kleinmayer, Julij, 74

Klopstock ("Messias"), 55

Kluchevsky, V. O., 66

Klun, Vinko F., 74

Kolo (of Zagreb), 27

Komenský ("Labyrinth"), 42

Kontistić, Petar, 58

Kopaonik (mine), 33

Kopitar, Jernej, 8

Korablica (of Kačić), 62

Korelin, Mih. Serg., 37

Kosovo (battlefield), 5I

Krralević, Marko, 52

Krčelić, Adam, 66

Krek, Ivan, 74

Krreševo (mine), 33

Kritoboulos of Imbros, 32

Križanić, Juraj, 66

Krmčija (Nomocanon), 23

Krmčija savinska, 23

Krstić, Nikola, 28

Krumbacher, Karl, I7

Krupań (mine), 33

Krylov (fabulist), 63

Kř́žek, Václav, 74

Kukulević, Iv., I4, 26, 65f., 74

Kulin, Ban, 13

Kušelev-Bezborodko, Gf. Gr., 25

$\mathrm{L}$

"Labyrinth of the World," 42

La Fontaine ("Fables"), 63

Lalić, Frano, 58

Lamanskij, V., 37

Language (purity of), 62

Language (theory of), I, 7, 14, 52 
Lascaris, Janus, 37

Latin alphabet, $70 f$.

Latin books, 32

Latin Church, 60

Latin civilization, 35

Latin derivatives, 4

Latin Empire, 3 I

Latin influence, 29

Latin letters, 62

Latin mythology, 55

Latin poets, $5^{8}$

Latin script, 8,13

Latin "shrewish girl," +5

Latin translation, 62

Lauchert, F., 20

Lavinia (of Palmotić), 55

Lavrov, P. A., $23 f$.

Laws, $16,27 f$.

Leban (Gradimir), Janko, 74

Legends, I2, I6, I8ff., 23, 60

Leger, Louis, I2, I4, 29, 64

Leroy-Beaulieu, I I

Leskien, August, 8, 49

Lessing ("Fables"), 63

"Letters" (of Chesterfield), 69

Lettic language, 7,9

Letopis matice srpske, 73, 75

Letopis Popa Duklanina, I4

Levant, 34

Life, v. Život

Life of Dečanski, 26

Linguistics, 2, 10, 69

Linguists, 58,68

literature, Iff., 24, 35, 43, 57, $70 f$. See also Jugoslav literature.

L.ithuanian language, 7,9

Liturgical books, 9, I6

Liturgical language, I I

Liturgical script, 8

Louvain, 66

Love songs, $35,3^{8 f .,} 44 f f ., 5^{6}$

Lovjagin, Evgraf, 16

Lucić, Hanibal, 39ff.

Lucretius ("De Rerum"), 67

Lučić, Ivan, v. Pavlović

Lukarević, Frano, 49
Luther, 68

Lyrics, 36, 43ff., 56

Lepava, J., 74

Lubav Venere, 47

Lubavnik Sramežliv', 50

Lubica (pastoral), 48

Lubić, Sima, 37, 74

Lubmir (of Zlatarić), 46

Isubuški, Lovro, 69

$\mathrm{M}$

Macedonia, 7, 35, 52

Macedonian Slavs, 8, I6

Macun, Ivan, 74

Maeterlinck ("Magdaleine"), 60

Magdalene (of Bunić), 56

Magdalene (of Đorđić), 59

Maixner, F., 46

Makowej, Ossip, 53

Malahna (farce), 48

Malalas, 18

Maltzew, A., I6

Manasses, Constantine, I 8

Mande (of Držić), 47

Manicheán sects, 2 I

Manuel (despot), 3 I

Maretić, Toma, 8

Margareta, 48, 54

Marica (river), $5 \mathrm{I}$

Marković, Frano, 53

Marseilles, 60

Martynov, Pater, 25

Marulić, Marko, 48

Marulus, E., 36

Marunko i Pavica (parody), 59

Maschus, 46

Matijaš Grabancijaš Đak, 69

Matijević, Đura, $5^{8}$

Matković, P., 37

Mažuranić, Antun, 27

Mažuranić, Ivan, 53

Mecca, 30

Medici, 44

Medini, Milorad, 37, 44, 48, 74 
Mediterranean Sea, 19, $3^{\circ}$

"Menaechmi" (of Plautus), 47

Menčetić (Menze), Šiško, $38 f$.

Menčetić, Vladislav, 65

Menea, 16

Mercia, 3

"Messias" (of Klopstock), 55

"Metamorphoses," 46, 54

Metastasio, 36

Methodius, $v$. St. Methodius

Mexico, 3 I

Mezimac (of Obradović), 64

Michael I (despot), 3 I

Michael II (despot), 3 I

Middle Ages, I, 15, 19f., 22, 35, 60

Mijatović, Čed., 3I , 74

Miklošić, F., 8, I2, I 4, I 8, 28, 3 I

Mikloušić, Tomaš, 68

Milan, 38

Milaš, Nikodim, 23

Milčetić, Ivan, 39,45

Mileševa (monastery), 26

Milišić, Miho, 66

Milton ("Paradise Lost"), 55

Milutin (king), 26, 33

Mines (ancient Jugoslav), 33

Miošić, v. Kačić

Miroslav, v. Gospel of

Mitrović, B., 74

Mohammed 11 (sultan), 32

Mohammedans, 2I, 4I, 5 I

Molière ("L'Avare"), 47

Montenegro, 29, 33, 62

Monasteries, 9, 11, 25ff., 61f.

Monumenta (historico-iuridica), 27

Monumenta serbica, 3 I

Monumenta (spect. historiam), 33

Monuments (written), I I, I3f., 70

Moralists, $v$. Jugoslav moralists

Moravia, 9, I2

Moravian legends, 12

Morea, $3 \mathrm{I}$

Morfill, W. R., 23, 74

Moslems, v. Mohammedans

"Mother Margareta" (ballad), 48

Mountains, v. Planine
"Much Ado About Nothing," 5.t

Mudrolubac Indijski, 69

Murko, M., 23, 74

Muškatirović, Jovan, 66

$\mathrm{N}$

Nalešković (Nale), Nikola, +tff.

Naples, 59

Narratives of Abraham, 2.3

Narratives of Adam, 23

Natali, Ivan v. Aletić

Natecańe Ujača $i$ Ulisa, 54

National bard, 6 I

National customs, 3

National ideals, 52

National language, 39

National life, 6 I

National literature, $7 \mathrm{I}$

National songs, 39, 48. See also Folk songs and Songs.

National speech, I, 3, 9

National spirit, 66

National tradition, 2, 9, 6I

Nations (theory of), 2

Naturalist, v. Fiziolog

Nauci Kalonovi (proverbs), 49

Near East, 34

Nemańa, $25 f ., 5^{2}$

Neretva (river), 30

Neo-Latin (languages), 34

New Testament, $v$. Bible

Newton, 67

Nicaea, 3 I

Nicodemus, v. Gospel of

Nikola, v. Gospel of

Nomocanon, see Krmcijı

Northumbria, 3

Norway, 33

Novaković, Stojan, $7 f$., 17, 20, 23ff., 28, 74

Novela od Stanca, 47

Novi (city), 27

Novi Sad (city), 67

Novo Brdo (mine), 33 
Obilić, Miloš, 52

Obradović, Dositije, 6I, 69, 7I

Principal works of, 63

Sketch of Life, 62

Summary of, 64

Octoechos, I6

Old Bulgarian, 8

Old Jugoslav literature, I3

Old Serbian, 8

Old Slavonic canons, I6

Old Slavonic hymnody, I6ff.

Old Slavonic language, 5, 7ff., I 7

Old Slavonic literature, $15 f f$.

Old Slavonic monuments, ifff.

Old Slovene, 8

Old Testament, $v$. Bible

Olimpia (drama), 65

Opera (of Bošković), 67

Orbin, Mavro, 66

Orfelin, Zaharija, 68

"Orlando Furioso," 54

Orthodox Church, 9, I $5 f$., 68

Orthodox Serbs, 29

Orthodox Slavs, Iof., 22

Orthography, Io, 70

Osman (epic), 66

Diction of, 53

Modelled on Tasso, $5 \mathrm{I}$

Citations from, $5^{2}$

Ostoja (king), 54

Ostojić, Tihomir, 62, 75

Otiosities, v. Plandovańa

Ovid, 46, 5I, $54 f$.

Oxford and Camb. Rev., 73

\section{$\mathrm{P}$}

Padua (city), 35, 46, 59

Palaeologus, Michael, 31

Paleo-Greek, 7

Paleo-Slavonic language, i $2 f$., 22

Paleo-Slavonic literature, 18

Paleo-Slavonic Nomocanon, 23

Paleo-Slavonic style, 26

Palmotić, Jaketa, 65

Palmotić, Junije, 50, 53ff., 70
Památky, 25

Pamjatniki, $24 f$.

"Pančatantra," I9

Pannonia, 9

Pannonic legends, I2

Pannonic Slavs, $8 f$.

Panslavism, I I, 66

Paradise, Garden of, 23

"Paradise Lost," 55

Paralipomena of Jeremiah, 23

Paris, 67

Parody, 48, 59

Pastirski Razgovori, 56

Pastorals, 43ff., 5o, 56

Pastrnek, F., 12

Patareni, v. Bogomils

Pavia, 67

Pavić, Arnim, 36f., 47, 53, 55

Pavić (Budua), Emerik, 4, 62, 68

Pavlimir (drama), 54

Pavlović, Ivan J. Lučić, 68

Pechan, Antun, 75

Peć (patriarchy), 26

Percy ("Reliques"), 6I $f$.

Persia, I 7

Pervenac (of Obradović), 64

Pesmarica (of Kačić), 6If.

Pesme svecima Srbima, I7

Pesni Duhovne (of Bunić), 56

Pesni Duhovne (of Dimitrović), 48

Pesni Duhovne (of Đorđić), 60

Pesni Luvezne (of Menčetić), 38

Pesni Razlike (of Zlatarić), 46

Pesni u Smrt (of Zlatarić), 46

Petar Aleksiević (epic), 58

Peter the Great, I0, 58

Petrarch, 38, 70

Petrović, Vasilije, 66

Petrović, Vićentije (Vinko), $5^{8}$

Phaedrus ("Fables"), 63

Philemon, 46

Philology, 3, 59, 69

Philologists, 8, I0, 13

Philosophy, I I, 2 I, 61ff., 67

"Phoenissae" (of Euripides), 49

Physiologus, see Fiziolog 
Pilgrim, see Putnik

Pindar, 17

Pindus, 8

Pjerin (of Držić), 47

Plam Severski (epic), $5^{8}$

Plandovańa (of Bunić), 56

Planine (pastoral), 48

Platonic love, 45

Plautus, 47

Poetry, v. Lyrics, Epics, and Dramas

Pohlin, Marko, 69

l'oland, 5 I

Poles, 2

Politics, 2I, 29, 4I, 52, 66

Polivka, George (Jiří), 20, 23, 24, 47,74

Pomet (of Držić), 47

Pope, Alexander, 45, 62

Popović, Ivan Žiga, 69

Popović, Pavle, $47 f$., 75

Popular dialect, 29

Popular literature, 22

Popular poetry, 20, 22, 39ff.

Popular writers, 62

Portugal, 33

Posilović, Pavle, 68

Poslanice (epistles), 43ff., 48

Posvetilište Abramovo, $4 \mathrm{I} f$.

Poučni Sastavi (of Dositije), 64

Povela Bana Kulina, I3

Požega (town), 68

Pravda (of Jaroslav), 28

Preux, Jules, 27

Pričice (epigrams), 48

Prijatel, Ivan, 75

Prikazańe sv. Beatrice, 48

Primeri (kńiž. i jezika), 7, I 7, 20

Primeri (starohrvat. jezika), I8

I'rince, John Dyneley, judgment of Old Slavonic language, 8

Pripoves od Krala Selimira, 59

Priština (city), 33

Prokopovič, Theofan, 66

Promotus Archimedis, 67

Propertius, 46

Proserpina (of Gundulić), $5^{0}$
Protevangelium of James, 24

Proto-Slavonic, 8

Provençal poetry, 35, $3^{8}$

Proverbs (of Solomon), I 2

Proverbs (of Cato), 49

Prvovenčani, Stefan, $25 f f$.

Psalms (of David), 15, 48, 59

Psalterium Sinaiticum, 13

Pucić (Pozza), Vićentije, 65

Pupin, Michael Idvorski, editor of

South Slav Monuments, 35

Puritans, 2 I

Puinik (of Vetranić), 42

Pypin, A. N., 25, 75

Pyramus and Thisbe, 46

\section{$Q$}

Questions of Bartholomew, 24

Questions of John Bogoslov, 24

Quirinal, 37

\section{$\mathrm{R}$}

Rad (jugoslovenske akademije), 8 , $2 \mathrm{I}, 32,37 f ., 44,46 f ., 53,55,58$, $62,67,69$

Radčenko, K., 64

Radoslav (king), 26

Rački, Frano, 12, 21, 27, 37

Ragusa, v. Dubrovnik

Rajić, Jovan, 64, 66

Rakić, Vićentije, 68

Ranke, Leopold, 32

Rańina (Ragnina), Dinko, 39, $45 f f$.

Rascia, v. Serbia

Rationalism, 6I, 63

Razboj od Turaka (epic', 48

Razgovor Ugodni, 6I $f$.

Reka (Fiume), 27

Religion, 2, 4, 2 I, 29, 35, 52

"Reliques" (of Percy), 62

Relković, Matija, 4, 65

Remeta (of Vetranić), 42

Renaissance, 29ff., 35ff., $7^{\circ}$

Republic of Dubrovnik, 29ff., 57.

See also Dubrovnik.

Republic of letters, 65 
Republic of Venice, $v$. Venice

Republican freedom, 30, 40

Resurrection, v. Uskrsnute

Rešetar, Milan, 48f., 53, 55

Revue des sc. politiques, 29

Revue slave, 35

Rheims, v. Gospel of

Rhetoric, I I, 59f.

Rhetorical figures, 60

Rhodope, 8

Ribane (of Hektorović), 48

Riches, v. Bogatstvo

Rilo (monastery), I I

Ristić, Jovan, 75

Robina (drama), 39

Rodoslov, see Carostavnik

Rome, 4, 30, 35, 47, 57, 59, 67

Roman influence, $4 f$.

Romanticism, $6 \mathbf{I}$

Romans, 4, 9

"Romeo and Juliet," +9

Ronsard, 70

Rudnik (mine), 3.3

Rumania, 26

Rumanian tongue, 9

Rumans (Vlachs), 34

Rusić, Stepo, 58

Russia, 12, 18, 58, 66

Russian bylinas, 20

Russian Church, 68

Russian fabulist, 63

Russian history, 66

Russian kobzars, 62

Russian language, $10 f$.

Russian manuscripts, 22

Russian Pravda, see Pravda

Russian recensions, 9

Russian sects, 12

Russian translation, 66

Russians, 2, $9 f$.

Russkaja běseda, $7+$

Russo-Slavonic, 9, I2 I, 68

$\mathrm{S}$

Sabor (congress), 27

St. Andrew of Crete, 17
St. Beatrice, v. Prikazanie of

St. Chrysostom, I6

St. Cosmos of Majumena, 17

St. Cyril, 8, roff.

St. Germanus, 17

St. James the Less, 24

St. Jerome, 9

St. John Damascus, 17

St. Joseph the Hymnographer, I7

St. Mark, I6

St. Martin, V. de, 31

St. Methodius, 7, I $1 f$.

St. Romanos, 17

St. Sava, I 7, $25 f f$.

St. Sergius, I7

St. Simeon, I 7, $25 f$.

St. Sophia (cathedral), I6

St. Sophronius, I 7

St. Stephen (martyr), 60

St. Thomas, v. Gospel of

St. Thomas Aquinas, 60

Salonika (Thessalonica), 7, 12

Saltir Slovenski, 59

Samblak, v. Camblak

Sasin, Antun, 48, 52

Satires, $49,55,58,69$

Sava, v. St. Sava

Savants, $v$. scientists

Saveti Zdravoga Razumu, 63

Saxons, 3,33

Savvina Kniga, I3

Schleicher, August, 8

Schmidt, Johannes, 8

Science, 20, 29, 59, 63

Scientists (savants), I3, 36, 44, 66

Scriptures, v. Bible

Sedam Opačina (satire), 49

Selimir (king), v. Pripores

Seń (Zengg), 27

Serb (short), $v$. Serbian

Serbia (Rascia), 12, 26, 31

Byzantine influence in, 35

Civil wars of, 30

Kings of, 26, $32 f$.

Methode's disciples in, I2

Part of Jugoslavia, 3 
Skople, old capital of, 34

Very fertile land, 32

Struggle for freedom, 3

Turkish invasion, $30 f$., 57

Under the sway of Russia, 68

Serbian Academy, v. Academies

Serbian authors, 69

Serbian biographies, $25 f$.

Serbian coins, 34

Serbian dialects, 39,68

Serbian history, 8, 66

Serbian hymns, 17

Serbian independence, 26

Serbian kings, 26, 32ff.

Serbian language, $3,55,68 f$.

Serbian legends, 12

Serbian literature, 26, 62f. See also Jugoslav literature.

Serbian lore, 20

Serbian manuscripts, 24

Serbian mines, $32 f$.

Serbian Orthodox saints, 17

Serbian recensions, 9, 18

Serbian society, 70

Serbian State, 5, $3 \mathbf{I} f$.

Serbian towns, 63

Serbian versions, 26

Serbians, 3ff., 10, 25, 52, 61, 66

Serblak or Srblak, 17

Serbo-Croat, v. Jugoslav

Serbo-Slavonic, 9, 12, 20

Sermons, v. Besede

Seven Penitential Psalms, 48

Seven vices, $v$. Sedam opačina

Severjanov, S., 13

Shakespeare, 20, 47, 49, 54

Simić, Živojin, P., 75

Simonić, Fr., 75

Skerlić, Jovan, 64, 75

Skople, v. Serbia

Skup (of Držić), 47

Slav (short), $v$. Slavonic

Slavdom, 12, $5^{2}$

Slaveni u Davnini, 8

Slavic (short), v. Slavonic

Slavic heroes, 54
Slavische Alterthümer, I6

Slavonia, 69

Slavonic apostles, 7, 9, I I

Slavonic Bible, v. Bible

"Slavonic Canzoniere," 38

Slavonic clans, 4

Slavonic dialects, $5,7 f$.

Slavonic documents, 22

"Slavonic Enoch," 23

Slavonic heraldry, 66

Slavonic heroes, 54

Slavonic history, 66

Slavonic languages, 2, 7, 39, 59

Slavonic literature, 8, 29, 63

Slavonic literary history, 3, I I

Slavonic Catholic liturgy, 9

Slavonic mythology, 55

Slavonic nations, 2, 1 1 , 37, 66

Slavonic philology, 3

Slavonic Psalter, v. Saltir

Slavonic publications, 18

Slavonic race, $2,5 \mathrm{I}$

Slavonic revival, 70

Slavonic soul, $4^{\circ}$

Slavonic spirit, 54

Slavonic States, 30, 34

Slavonic translation, 13

"Slavonic Xenophon," 69

Slavo-Serbian, 68

Slavs, 2, 7f., I 1, 24, 41, 66

Slovene (short), $v$. Slovenian

Slovenia, 3, 5, 68

Slovenian authors, 69

Slovenian Bible, 68

Slovenian documents, 13

Slovenian language, 68

Slovenian reformers, 68

Slovenians, $3 f f$., $6 \mathrm{r}$

Slovnik naučný, 74

Slovnik umetnika jug., 74

Smederevo (city), 5I

Smirnov, Ivan, 57

Sobolevskij, A. Iv., Io

Social conditions, 6 I

Social eminence, 46

Social life, 46, 63, 66 
Social literature, 7 I

Social organization, 57

Sofia (city), 34

Solarić, Pavle, 8, 62, 68f.

Solomon, 12, 20, 23

Songs, 4Iff., 48, 62

Sophocles, $46 f$.

Sorkočević (Sorgo), Petar, 53

Southern Slav, v. Jugoslav

Spain, 3I, 35

Speranskij, M. N., 24

Spiritual songs, $4^{8}, 56,60$

Splet (city), 9

Srebrenica (mine), 33

Srem (Syrmia), 62

Sreznevskij, I., Io

Srpska kńiževna zadruga, $63 f$.

Stanojević, Stanoje, 75

Stari pisci, 39, 43, 48, 53, 55, 65

Starine (jugoslovenske akademije)

Io, I8, 20, $23 f f$.

Statius ("Achilleis"), 55

Statute-books, v. Typiks

Stead, Alfred, 75

Stemmatography, 66

Stepan, Herceg, 52

Stephanit and Ichnilat, 19

Stepovič, Andronik, 75

Stojanović, Lubomir, I3, 24

Stojković, Atanasije, $66 f$.

Stojković (Stoicus), Ivan, 37

Studenica (monastery), I I, 25

Style (in architecture), I6, 35

Style (literary), 38, 48, 62ff.

Subotić, Jovan, 75

Susanna (of Marulić), 48

Susanna (of Vetranić), $4 \mathrm{I}$

Suze Sina Razmetnoga, 50

Swift, Jonathan, 62

Symbolism, 19, 23

Syria, 22, 31

Syriac originals, 20

Syrmia, $v$. Srem

Šafařík, Janko, 26, 34
Šafařík, Paul Josef, I3, I6, 25ff., 44, 48,75

Ščepkin, V., I3

Šercer, Ivan, 64

Šević, Milan, 64

Sibenik (city), 6I

Sišatovac, v. A postolus of

Šrepel, Milivoj, 47

Šurmin, Đura, $4^{8}, 74 f$.

$\mathrm{T}$

Tabor (Mount), 24

Tafel, G. L. F., 3 I

Talvi (Therese A. L. von Jakob, Mrs. Robinson), 37

Tasso, 46f., 5I, 54

Tassoni, A., 45

Tears of the Prodigal Son, 50, 56

Teodosije, $26 f f$.

Terence ("Andria"), 47

Teutonic peoples, 9

Theocritus ("Idyls"), 56

Theology, Iof., I 7, 61

Theologians, 37, 68

Theoria Philosophiae, 67

Thomas, G. M., 3 I

Tibullus, 46

Tihonravov, N. S., $24 f$.

Tirena (of Držić), 47

Tolstoy, Leo, 2 I

Tozer, H. F., I6

Translations, 8, I I $f$., I $7 f$., 46, 48f., 59f., 66, 68f.

Transylvania, 33

Trebizond, $3 \mathbf{I}$

Trlajić, Grigorije, 68

Trojanski Rat, 18

Troubadours, $38 f f$.

Trubar, Primož, 68

Tsamblak, v. Camblak

Tunis, 3 I

Turkey, $5 \mathbf{I}$

Turkish conquest, 5

Turkish inroads, 6 I

Turkish yoke, 4I 
Turks, 2 I, 39ff., 48, 57

Typiks (statute-books), 25

$\mathrm{U}$

Ukrainians (Little Russians), 2

Uniats (Greek Catholics), I2

Universities, 20, 35, 37, 46, 6of.

Uroš I (king), 26, $32 f$.

Uroš II (king), v. Milutin

Uskrsnuce Isukrstovo, $4 \mathrm{I}$

Uzdasi Mandalene Pokornice, 59

\section{$\mathrm{V}$}

Valvasone, Erasmo da, 60

Valvazor, Ivan, 66

Vatican, I8

Vazeije Sigeta Grada, 48

Venice, 29f., 57, 59

"Venus and Adonis," 47

Verni Pastir (pastoral), 49

Vetranić, Mavro, 4Iff., $5^{2}$

Vida, Marco, 55

Vidović, M. A., 60

Vienna, 65

Vila Slovinka (epic), 48

Vinodolski Zakon (code), 27

Virgil, 46, 5I, 55

Virgin, Mary, I7, 24

Vita, v. Žitie

Vitae el Carmina, 59

Vitezović, Pavle, 65

Vitković, Gavrilo, 66

Vladislav (king), 26

Vojnović, Lujo, 30

Vondrák, Václav (Wenzel), 8, 10, I3

Voronov, A. D., I2f.

Vostokov, Aleksandr, I8

Voyage of the Virgin, 24

Voyage of the A postle Paul, 24

Vrańe (city), 33
Vulović, Svetislav, 25, 75

Vzbranoj Voevode (hymn), 17

W

Wessex (ancient province), 3

Western Church, 21

Western Europe, I8f., 35

Wesiminster Review, 74

Wilkinson, J. G., 29, 32

Women, 35, 46, 49, 58, 63

Z

Zadruga (family community), 4 Zagreb (capital), ข. Croatia

Zakonu pravilo, see Krmčija

Zaostrog (monastery), 6I

Zbornik (za istoriju), 73

Zeta, $v$. Montenegro

Zlatarić, Dinko, $46 f f$.

Zograf (monastery), II, I3

Zoranić, Petar, 48

Zore, Luka, $43 f$., 53

Zorislava (drama), 65

Zriński, Petar, 65

Zuzorić (Zuzzeri), Bernardo, $5^{8}$

Zuzorić (Zuzzeri), Cveta, 46, 49

Zvornik (mine), 33

$\check{Z}$

Žefarović, Hristifor, 66

Žiča (monastery), 26

Žilie Konstantina Filosofa, I2

Žilie sv. Metodia, 12

Životi kraleva srpskih, 26

Život i Prik」učenija, 63

Život sv. Jerolima, Io

Život sv. Save, 26

Život sv. Simeuna, $25 f$.

Žurnal ministerstva, 57 



\section{COLUMBIA UNIVERSITY PRESS}

Columbia University in the City of New York

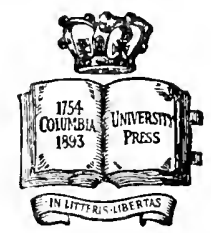

The Press was incorporated June $8, \mathbf{1 8 9 3}$, to promote the publication of the results of original research. It is a private corporation, related directly to Columbia University by the provisions that its Trustees shall be officers of the University and that the President of Columbia University shal! be President of the Press.

The publications of the Columbia University Press include works on Biography, History, Economics, Education, Philosophy, Linguistics, and Literature, and the following series:

Columbia University Contributions to Anthropology.

Columbia University Biological Series.

Columbia University Studies in Cancer and Allied Subjects.

Columbia University Studies in Classical Philology.

Columbia University Studies in Comparative Literature.

Columbia University Studies in English.

Columbia University Geological Series.

Columbia University Germanic Studies.

Columbia University Indo-Iranian Series.

Columbia University Contributions to Oriental History and Philology.

Columbia University Oriental Studies.

Columbia University Studies in Romance Philology and Literature.

Columbia University Slavonic Studies.

Records of Civilization: Sources and Studies.

Adams Lectures.

Julius Beer Lectures.

Blumenthal Lectures.
Carpentier Lectures.

Hewitt Lectures.

Jesup Lectures.

Catalogues will be sent free on application.

\section{LEMCKE \& BUECHNER, Agents} 30-32 East 2oth St., NEW YORK 


\title{
RUSSIAN GRAMMAR
}

\author{
For Class and Reference Use \\ By John Dyneley Prince
}

Professor of Slavonic Languages, Columbia University

$$
\text { Cloth, pp. } 2 \text { I I } \$ 2.50 \text { net }
$$

The need has long been felt for a series of progressive lessons for beginners in Russian which shall at the same time serve as a reference grammar without confusing the student. The object of this book is to furnish the student with the elementary facts as to the mechanism of the language, and also with such full paradigms and other examples of the complicated substantive and verb systems as may serve as an aid, not only in reading Russian, but also in translating from English into Russian. The work will be of value both to students and to instructors in setting forth inductively the most salient facts of Russian grammar.

\section{COLUMBIA UNIVERSITY SLAVONIC STUDIES}

Edited by the Slavonic Department

\section{Volume 1. EARLY JUGOSLAV LITERATURE, IOOO-} I 800 . By Milivoy S. Stanoyevich, Ph.D. 8vo, paper, pp. viii + 92. \$I.50 net.

This volume is a literary history written on a new principle. The author regards the literature primarily as an expression of national and social forces. He aims to present the progress of the South Slavonic languages and literature through eight centuries, showing the influences which gathered three smaller tributaries (Serb, Croat and Slovene) in one (Jugoslav) stream.

\section{COLUMBIA UNIVERSITY PRESS}

LEMCKE \& BUECHNER, AGENTS 






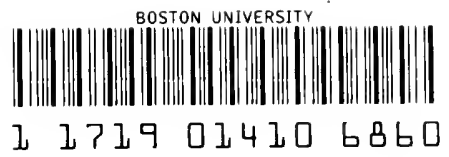

DO NOT FILEUVE

CHARER SLP FRE A TH POMT

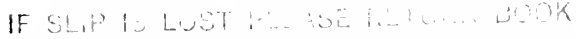

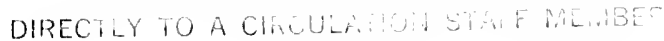




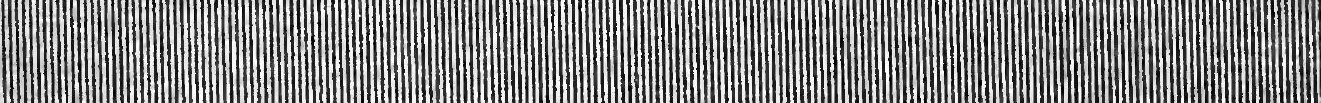

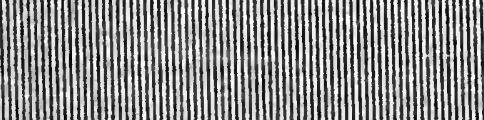

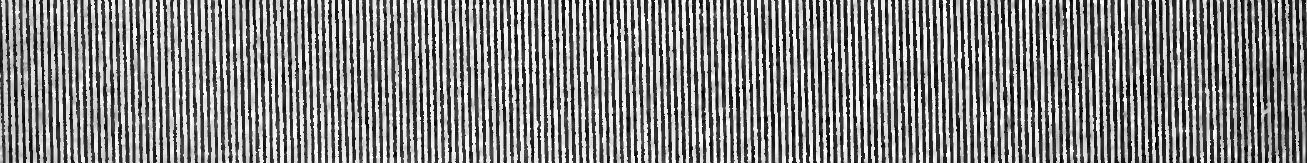
W N) (3) |

s.

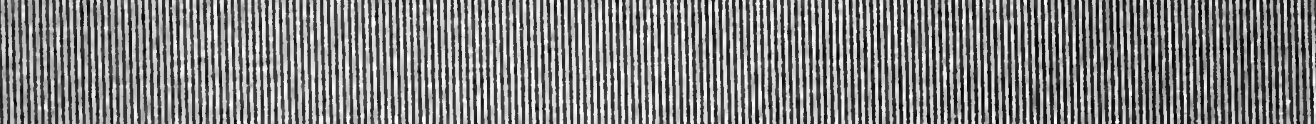

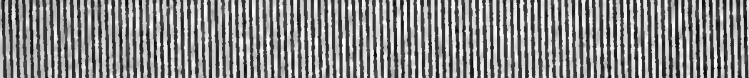

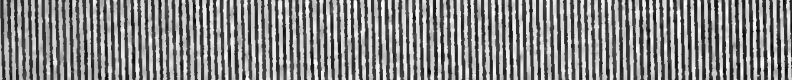

| \begin{tabular}{|l|l|}
$\mid$ & $\mid$
\end{tabular} |. |

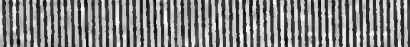

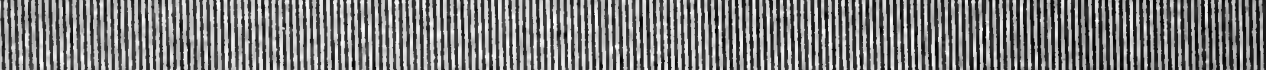
$5 \mid$ (1) |6

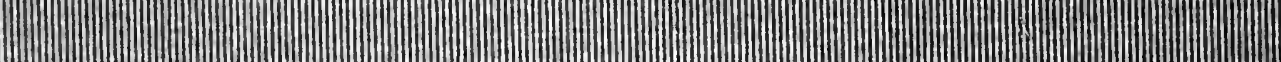
|.

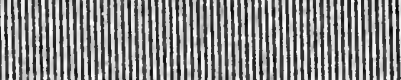

|

(1) |

|

|1

(1) (1) (1)

m. m. 